\title{
HUBUNGAN KEPUASAN KERJA DAN MOTIVASI KERJA DENGAN KINERJA PEGAWAI NEGERI SIPIL PADA DINAS KESEHATAN KABUPATEN TAPANULI UTARA
}

\author{
SKRIPSI \\ Diajukan Kepada Fakultas Universitas Medan Area \\ Guna Memenuhi Sebagian Dari Syarat-syarat \\ Dalam Meraih Gelar Sarjana (S1) Psikologi
}

OLEH :

FLORENSYA ROMAULY

13.860.0092

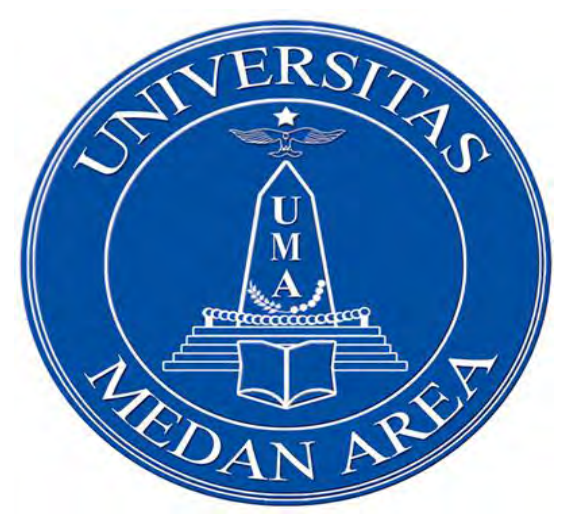

FAKULTAS PSIKOLOGI

UNIVERSITAS MEDAN AREA

MEDAN

2017 


\section{HALAMAN PENGESAHAN}

\section{DIPERTAHANKAN DI DEPAN DEWAN PENGUJI SKRIPSI FAKULTAS PSIKOLOGI UNIVERSITAS MEDAN AREA DAN DITERIMA UNTUK MEMENUHI SEBAGIAN DARI SYARAT-SYARAT GUNA MEMPEROLEH GELAR SARJANA (S1) PSIKOLOGI}

\section{Pada Tanggal}

30 November 2017

FAKULTAS PSIKOLOGI

UNIVERSITAS MEDAN AREA

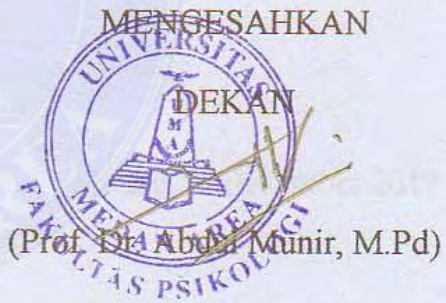

\section{DEWAN PENGUJI}

1. Dra. Ima Minauli, M.Si

2. Azhar Azis, S.Psi, M.A

2. Dra. Mustika Tarigan. M.Psi

3. Suryani Hardjo, S.Psi, MA
TANDA TANGAN

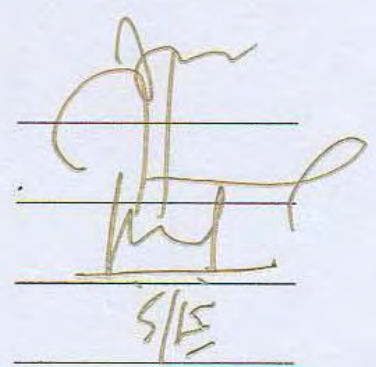




\section{HALAMAN PERSETUJUAN}

JUDUL SKRIPSI

HUBUNGAN KEPUASAN KERJA DAN MOTIVASI KERJA DENGAN KINERJA PEGAWAI NEGERI SIPIL PADA DINAS KESEHATAN KABUPATEN TAPANULI UTARA
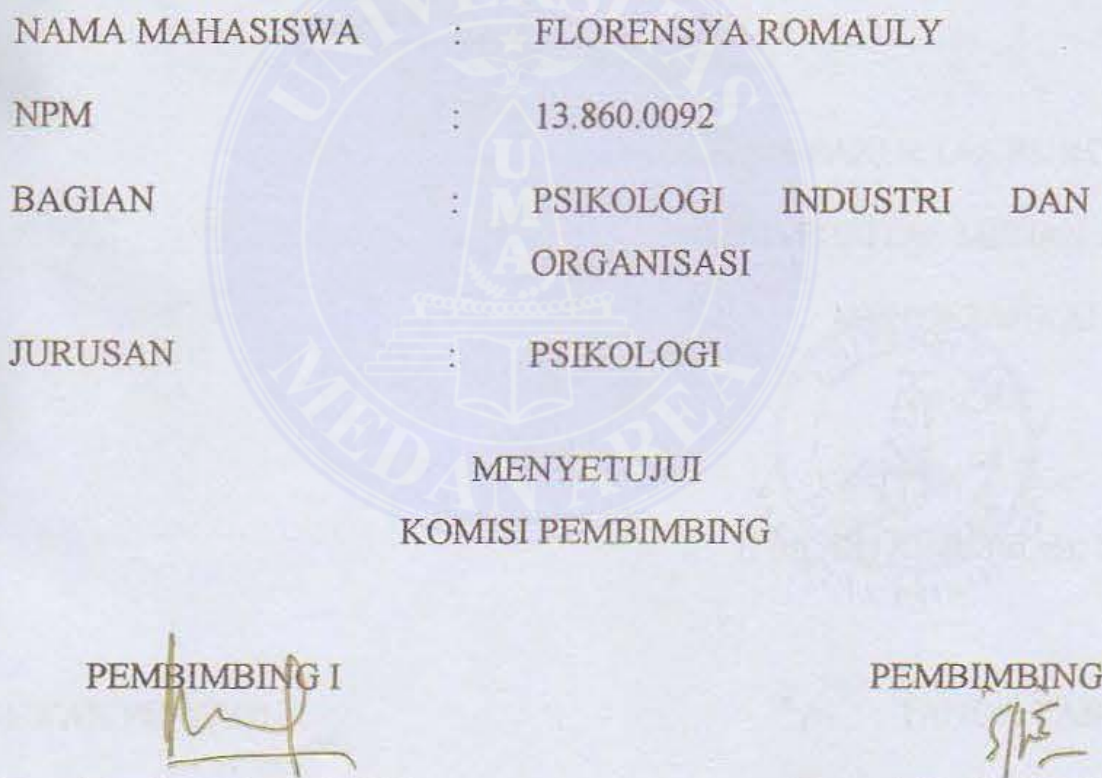

PEMBIMBING II

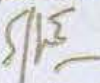

(Dra. Mustika Tarigan, M.Psi)
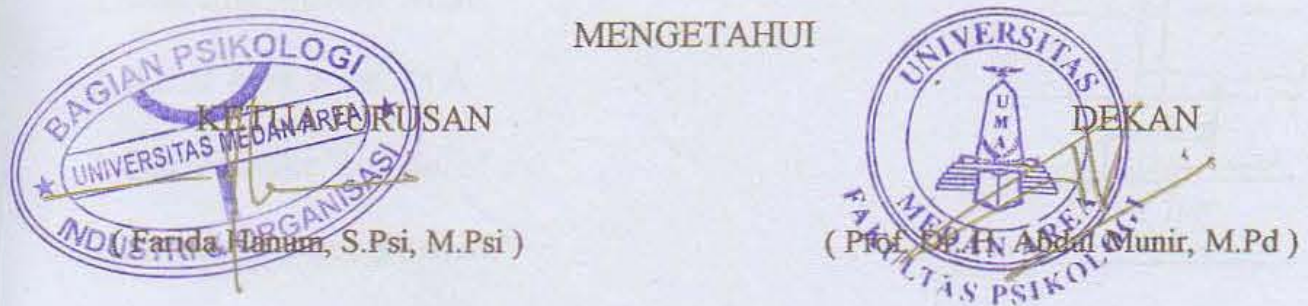

Tanggal Sidang Meja Hijau

30 November 2017 


\section{LEMBARAN PERNYATAAN}

Saya menyatakan bahwa skripsi yang saya susun, sebagai syarat memperoleh gelar sarjana merupakan hasil karya tulis saya sendiri. Adapun bagian-bagian tertentu dalam penulisan skripsi ini yang saya kutip dari hasil karya orang lain dituliskan sumbernya secara jelas sesuai dengan norma, kaidah dan etika penulisan ilmiah.

Saya bersedia menerima sanksi pencabutan gelar akademik yang saya peroleh dan sanksi-sanksi lainnya dengan peraturan yang berlaku, apabila dikemudian hari ditemukan adanya plagiat dalam skripsi ini.

Medan, Desember 2017

Florensya Romauly

13.860.0092 
UNIVERSITAS MEDAN AREA 


\title{
ABSTRAK \\ HUBUNGAN KEPUASAN KERJA DAN MOTIVASI KERJA DENGAN KINERJA PEGAWAI NEGERI SIPIL PADA DINAS KESEHATAN KABUPATEN TAPANULI UTARA
}

\author{
Oleh: \\ FLORENSYA ROMAULY \\ 13.860.0092
}

Penelitian ini bertujuan untuk melihat hubungan antara kepuasan kerja dan motivasi kerja dengan kinerja. Subjek penelitian ini melibatkan 86 orang Pegawai Negeri Sipil Dinas Kesehatan Kabupaten Tapanuli Utara dan pengambilan sampel dilakukan dengan teknik Total Sampling. Metode pengumpulan data yang digunakan dalam penelitian ini adalah metode skala dan metode dokumentasi. Metode skala yang digunakan yaitu skala kepuasan kerja dan skala motivasi kerja. Dokumen berupa nilai prestasi kerja Pegawai Negeri Sipil yang diperoleh dari bagian kepegawaian. Metode analisis data yang digunakan dalam penelitian ini adalah regresi berganda, berdasarkan analisis data, diperoleh bahwa hipotesis yang diajukan dalam penelitian ini dinyatakan diterima, yaitu ada ada hubungan kepuasan kerja dan motivasi kerja dengan kinerja Pegawai Negeri Sipil Dinas Kesehatan Kabupaten Tapanuli Utara. Hal ini dibuktikan melalui perhitungan analisis Regression, dengan nilai $\mathrm{F}=8.406$ dengan nilai $\mathrm{Sig}=$ 0.000 , Hal ini berarti nilai $p<0.05$ yang artinya signifikan. Kepuasan kerja dan motivasi kerja memberikan kontribusi terhadap kinerja sebesar $\mathrm{R}=$ 0.410 (41\%). Serta secara umum, kepuasan kerja dan motivasi kerja tergolong baik terhadap kinerja, dengan diketahui dari (mean hipotetik kepuasan kerja 67,5 < mean empirik kepuasan kerja 77). Begitu juga dengan (mean hipotetik motivasi kerja $145<$ mean empirik motivasi kerja 170).

Kata Kunci : Kepuasan kerja, motivasi kerja, kinerja, Pegawai Negeri Sipil Dinas Kesehatan. 


\title{
ABSTRACT \\ RELATIONSHIP WORK SATISFACTION AND EMPLOYMENT MOTIVATION WITH PERFORMANCE OF CIVIL SERVANT EMPLOYEES IN DEPARTMENT OF HEALTH OF TAPANULI DISTRICT NORTH
}

\author{
By: \\ FLORENSYA ROMAULY \\ 13.860.0092
}

This study aims to see the relationship between job satisfaction and work motivation with performance. The subjects of this study involved 86 Civil Servants of Health Office of North Tapanuli Regency and sampling was done by Total Sampling technique. Data collection method used in this research is method of scale and method of documentation. Scale method used is job satisfaction scale and work motivation scale. Documents in the form of performance value of Civil Servants obtained from the employment department. The method of data analysis used in this study is multiple regression, based on data analysis, it is found that the hypothesis proposed in this study is stated accepted, that there is no relationship of job satisfaction and work motivation with the performance of Civil Servant of North Tapanuli District Health Office. This is proven through calculation of Regression analysis, with value $\mathrm{F}=8.406$ with value of $\mathrm{Sig}=0.000$, It means value of $\mathrm{p}<0.05$ meaning significant. Job satisfaction and work motivation contributed to the performance of $\mathrm{R}=0.410$ (41\%). And in general, job satisfaction and work motivation are good for performance, with known from (mean hypothetical job satisfaction $67,5<$ empirical mean job satisfaction 77 ). The same is true (hypothetical mean work motivation 145 <empirical mean work motivation 170).

Keywords: Job satisfaction, work motivation, performance, Civil Servant of Health Office. 


\section{Motto}

" Kamu adalah garam dunia.

Jika garam itu menjadi tawar, dengan apakah ia diasinkan ?

Tidak ada lagi gunanya selain dibuang,

Dan diinjak orang "

( MATIUS 5:13)

” Apapun juga yang kamu perbuat, perbuatlah dengan segenap hatimu seperti anak Tuhan dan bukan untuk manusia"

( Kolose 3: 23 )

"Whatever you do, work at it with all your heart, as working for the Lord, not for human masters"

(Colossians 3:23) 


\section{Persembahan}

Kupersembahkan dan kuhadiahkan karya sederhana ini kepada kedua orang tuaku tercinta, Ayahku Jhonny Efendy, SH, MAP dan Ibuku Longseria Gea.

Terima kasih yang tak terhingga, untuk semua doa, cinta dan kasih sayang yang sampai sekarang selalu memberi warna dalam hidupku.

Dan kupersembahkan pula kepada Opung Ku yang tinggal satu-satunya, abang dan adik-adikku tercinta

Op. Dungo Simanjuntak, abang Thomas Pandapotan Sihombing, abang Roy Hendra Sihombing, abang Roy Hendri Sihombing, adek Josua Pardamean Sihombing.

yang selalu mengingatkanku untuk tidak mudah menyerah dalam menjalani didunia perantauan ini.

Terima kasih untuk semuanya

I LOVE YOU 


\section{UCAPAN TERIMA KASIH}

Dengan mengucap puji dan syukur kehadirat Tuhan Yang Maha Esa atas segala rahmat dan karunia-Nya, penulis dapat menyelesaikan skripsi ini dengan judul ” Hubungan Kepuasan Kerja dan Motivasi Kerja dengan Kinerja Pegawai Negeri Sipil Pada Dinas Kesehatan Kabupaten Tapanuli Utara ”. Skripsi ini merupakan salah satu syarat untuk memperoleh gelar Sarjana Psikologi pada Fakultas Psikologi Universitas Medan Area.

Penulis menyadari sepenuhnya bahwa tulisan ini masih jauh dari kata sempurna. Disamping itu, masih banyak kekurangan serta kejanggalan disanasini. Untuk itu, pada kesempatan ini kritik dan saran yang bersifat membangun sangat peneliti harapkan demi sempurnanya Skripsi ini.

Dalam hal ini, penulis ingin menyampaikan rasa terima kasih kepada semua pihak yang telah membantu dalam penyusunan Skripsi ini. Sebab penulis sadar tanpa bantuan tersebut, penulisan ini tidak akan terselesaikan dengan baik untuk itu penulis mengucapkan terima kasih kepada :

1. BPH - Yayasan Pendidikan Haji Agus Salim yang telah mendirikan Universitas Medan Area.

2. Bapak Prof. Dr. H. A. Ya'kub Matondang, MA selaku Rektor Universitas Medan Area.

3. Bapak Prof. Dr.H. Abdul Munir, M.Pd selaku Dekan Fakultas Psikologi Universitas Medan Area. 
4. Bapak Zudhi Budiman, S.Psi, M.Psi selaku wakil dekan I Fakultas Psikologi Universitas Medan Area.

5. Bapak Khairul Anwar Dalimunte, S.Psi, M.Si selaku wakil dekan III Fakultas Psikologi Universitas Medan Area.

6. Ibu Dra. Irna Minauli, M.Si, sebagai ketua sidang saya yang mau meluangkan waktu untuk mengadakan sidang meja hijau peneliti

7. Bapak Azhar Azis, S.Psi, MA, sebagai sekretaris disidang saya yang mau meluangkan wktu untuk mengadakan sidang meja hijau peneliti

8. Ibu Dra. Mustika tarigan, M.Psi sebagai Pembimbing I, terima kasih atas waktu dan bimbingan Ibu serta perhatian yang tidak terhingga telah bersedia begitu banyak memberi arahan dan bimbingannya.

9. Ibu Suryani Hardjo, S.Psi, MA sebagai Pembimbing II, terima kasih atas perhatian dan semangat serta arahan yang tidak terhingga yang telah diberikan

10. Dosen Fakultas Psikologi yang selama ini memberikan banyak ilmu dan pembelajaran yang sangat berharga.

11. Kepala Dinas Kesehatan Kabupaten Tapanuli Utara, terima kasih telah memberikan izin kepada peneliti untuk melakukan penelitian.

12. Para Pegawai Negeri Sipil Dinas Kesehatan Kabupaten Tapanuli Utara, yang telah bersedia untuk menjadi subjek penelitian

13. Ayahku tercinta Jhonny Efendy, SH, MAP dan Mamaku tercinta Longseria Gea yang telah memberikan semangat, dukungan, motivasi, kasih sayang 
dan doa yang tak terhenti-hentinya kepada penulis selama menjalani perkuliahan hingga selesai.

14. Kesayanganku Saloma Sitanggang yang telah meluangkan waktunya untuk membantu penulis dalam penyelesaian skripsi ini dan terima kasih untuk semangat serta membuat hari-hari yang sulit terasa ringan dan dukungan selama ini.

15. Tulang, nantulang, beserta keluarga lainnya yang ada di Jambi yang selalu memberi semangat dalam penyelesaian skripsi ini

16. Uda dan orang bou yang ada dikampung juga yang selalu memberi semangat dalam menjalani setiap permasalahan yang ada dengan hidup bersyukur sampai peneliti menyelesaikan skripsi ini

17. Sahabat terutama kepada teman-teman seperjuanganku stambuk 13 Anak REG.B Pagi khususnya, yang tidak dapat penulis sebutkan satu persatu.

Akhir kata penulis mengucapkan terima kasih yang sebesar-besarnya kepada semua pihak yang turut membantu penulis dalam menyelesaikan skripsi ini. Hanya kepada Tuhan Yang Maha Kuasa penulis serahkan segalanya, yang dapat membalas segala kebaikan yang telah penulis terima.

Medan, Desember 2017

Penulis 


\section{DAFTAR ISI}

\section{Halaman}

HALAMAN PERSETUJUAN ......................................................... i

HALAMAN PENGESAHAN ............................................................ ii

LEMBARAN PERNYATAAN ............................................................... iii

MOTTO

PERSEMBAHAN _...............................................................................

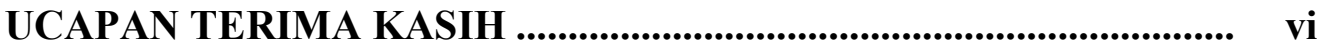

ABSTRAK .................................................................................................. ix

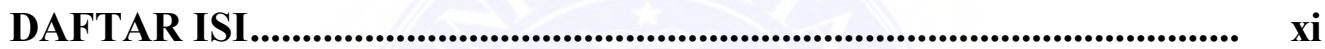

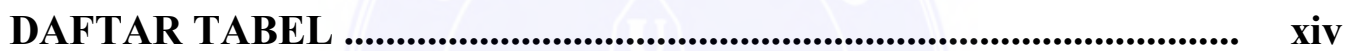

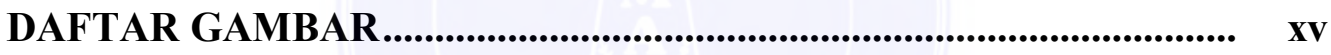

DAFTAR LAMPIRAN ............................................................................. xvi

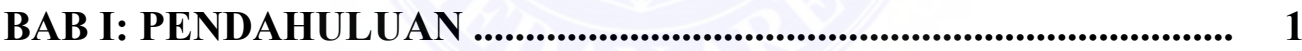

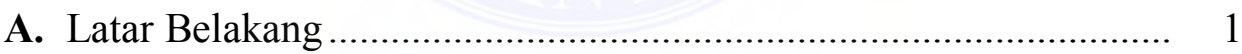

B. Identifikasi Masalah..................................................................... 7

C. Batasan Masalah ......................................................................... 8

D. Rumusan Masalah.................................................................... 8

E. Tujuan Penelitian ...................................................................... 8

F. Manfaat Penelitian ....................................................................... 9 


\section{Halaman}

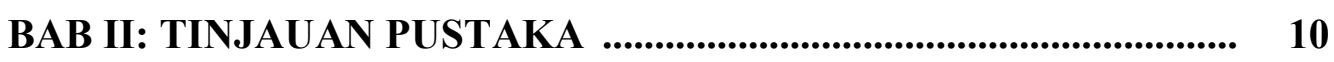

A. Pegawai Negeri Sipil.............................................................. 10

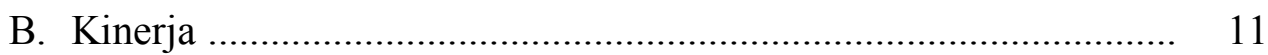

C. Kepuasan Kerja ...................................................................... 21

D. Motivasi Kerja _................................................................... 29

E. Hubungan Antar Variabel ......................................................... 42

F. Kerangka Konseptual........................................................... 51

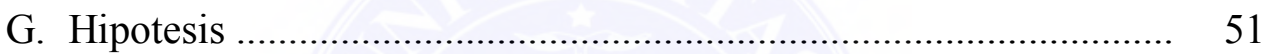

BAB III : METODOLOGI PENELITIAN ........................................ 53

A. Tipe Penelitian ............................................................... 53

B. Identifikasi Variabel Penelitian................................................... 53

C. Definisi Operasional Variabel Penelitian......................................... 54

D. Subjek Penelitian ...................................................................... 55

E. Metode Pengumpulan Data...................................................... 56

F. Validitas dan Reliabilitas Alat Ukur .......................................... 61

G. Metode Analisis Data................................................................ 63

BAB IV HASIL PENELITIAN DAN PEMBAHASAN ..................... 66

A. Orientasi Kancah dan Persiapan Penelitian .................................... 66

B. Pelaksanaan Penelitian............................................................. 73

C. Analisis Data dan Hasil Penelitian............................................... 76

D. Pembahasan.............................................................................. 84 


\section{Halaman}

BAB V KESIMPULAN DAN SARAN .............................................. 94

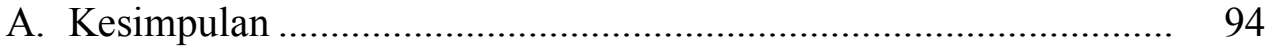

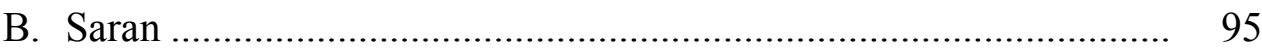

DAFTAR PUSTAKA 


\section{DAFTAR TABEL}

\section{Halaman}

Tabel 3.1 59

Tabel 4.1 70

Tabel 4.2 72

Tabel 4.3 74

Tabel 4.4 75

Tabel 4.5 77

Tabel 4.6 78

Tabel 4.7 80

Tabel 4.8 82 


\section{DAFTAR GAMBAR}

\section{Halaman}

Gambar 4.1

83

Gambar 4.2

83 


\section{DAFTAR LAMPIRAN}

\section{Halaman}

Lampiran A (Skala Penelitian kepuasan kerja dan motivasi kerja)... $\quad 101$

Lampiran B (Data Kepuasan Kerja Sebelum dan Sesudah Uji Coba) ... 112

Lampiran C (Data Motivasi Kerja Sebelum dan Sesudah Uji Coba) ..... 124

Lampiran D (Hasil Uji Validitas Skala penelitian) ....................... 143

Lampiran E (Hasil Uji Normalitas Skala Penelitian) .................... 152

Lampiran F (Hasil Uji Linearitas Skala Penelitian).................... 154

Lampiran G (Hasil Uji Asumsi dan Hipotesis Skala Penelitian) ..... 161

Lampiran H (Struktur Organisasi) .......................... 167

Lampiran I (Dokumen Kinerja Pegawai/SKP) ................. 169

Lampiran J (Surat Keterangan Bukti dan Selesai Penelitian)........ 179 


\section{BAB I}

\section{PENDAHULUAN}

\section{A. Latar Belakang}

Dinas Kesehatan Kabupaten Tapanuli Utara adalah salah satu Instansi pemerintahan. Dalam sebuah Instansi pemerintahan, ada Kepala Dinas, Kepala Bagian, yang salah satu tugas dan fungsinya adalah merumuskan program kerja.

Pengukuran Capaian Kinerja Organisasi atas setiap sasaran-sasaran strategis pada setiap program kerja berdasarkan indikator-indikator keberhasilan pencapaian sasaran-sasaran strategis Dinas Kesehatan Kabupaten Tapanuli Utara, dapat dilihat berdasarkan program - program kerja sebagai berikut : Program Pencegahan dan Pemberantasan Penyakit Dan Penyehatan Lingkungan, Program Pelayanan Kesehatan Masyarakat (YANKESMAS), Program Peningkatan Kesehatan Masyarakat (PKM), Program Pembinaan Kesehatan Masyarakat (BINKESMAS), Program Sarana Kesehatan dan Pemberdayaan Sumber Daya Manusia Kesehatan.

Adapun yang melaksanakan semua program - program kerja dari instansi diatas adalah pegawai atau bawahan yang disebut pegawai negeri sipil. Sebutan Pegawai Negeri Sipil saat ini telah diganti menjadi Aparatur Sipil Negara.

Aparatur Sipil Negara adalah sebagai penyelenggara negara yang terdapat dalam semua lini pemerintahan. Menurut (Pasal 1 ayat (1) Undang-undang Nomor 43 Tahun 1999 tentang Perubahan Atas Undang- 
undang Nomor 8 Tahun 1974 tentang Pokok-pokok Kepegawaian), disebut bahwa Pegawai Negeri adalah setiap warga Negara Republik Indonesia yang telah memenuhi syarat yang ditentukan, diangkat oleh pejabat yang berwenang dan diserahi tugas dalam suatu jabatan negeri, atau diserahi tugas negara lainnya dan digaji berdasarkan peraturan perundang-undangan yang berlaku. Dengan demikian, mengingat kompleksitas pekerjaan mereka sebagai ujung tombak dan supaya lancar semuanya itu, dibutuhkan kinerja yang maksimal dari Pegawai Negeri Sipil.

Kinerja adalah hasil yang dicapai dari apa yang diinginkan oleh organisasi (Ivancevich, 2012), menurut Colquitt (2011), bahwa kinerja adalah nilai dari seperangkat perilaku Pegawai yang berkontribusi, baik secara positif atau negative terhadap pemenuhan tujuan organisasi.

Adanya kinerja yang tinggi pada pegawai akan membuat Pegawai terhindar dari perilaku - perilaku keorganisasian yang negatif misalnya : membolos, mangkir kerja, pindah kerja ke perkantoran lain, mengeluh, tidak peduli dengan hasil pekerjaan yang dilakukan, tidak percaya diri, meninggalkan jam kerja, dan lain sebagainya.

Rendahnya kinerja pada pegawai bisa saja terjadi karena tidak terpenuhinya keinginan yang diharapkan. Sehingga akan memunculkan dampak-dampak yang kurang sesuai oleh harapan organisasi tersebut. Adapun permasalahannya seperti merasa tidak mampu, merasa posisi atau kedudukannya akan digantikan dengan tidak sesuainya bidang yang 
dimiliki, merasa tidak puas akan gaji yang di dapatkan, merasa kinerja yang dicapai tidak sesuai dengan skill atau kemampuan dan lain sebagainya.

Ada beberapa faktor yang mempengaruhi kinerja diantaranya adalah Kepuasan Kerja dan Motivasi Kerja menurut Robbin (dalam Kasmir, 2016). Kepuasan kerja adalah perasaan menyokong atau tidak menyokong yang dialami pegawai dalam bekerja menurut Keith Davish (dalam Mangkunegara, 2013). Menurut Wexley dan Yukl (dalam Mangkunegara, 2013), kepuasan kerja merupakan cara Pegawai merasakan dirinya atau pekerjaannya.

Menurut Aydogdu (dalam Alamsyah, 2015), Ciri-ciri karyawan yang menunjukan kepuasan kerja yang rendah adalah tingkat ketidakhadiran yang tinggi, meningkatnya turnover, rendahnya produktivitas kerja, tidak tercapainya prestasi, keputusan untuk melakukan pensiun dini, kesehatan fisik dan mental menurun hingga merasakan ketidakpuasan dalam hidup. Dengan demikian dapat dikatakan bahwa pegawai yang tidak memperoleh kepuasan kerja, maka dalam bekerjanya dia tidak bisa menyelesaikan pekerjaannya karena dia merasa tidak mampu dalam berprestasi dan tidak sungguh-sungguh dalam bekerja. Sehingga hal tersebut, tentu akan membuat kinerjanya menurun.

Menurut Luthans (dalam Alamsyah, 2015), ciri-ciri karyawan yang menunjukan kepuasan kerja yang tinggi adalah memiliki pecapaian prestasi kerja, kesehatan fisik yang lebih baik, lebih produktif, memelajari 
tugas yang berhubungan dengan pekerjaan baru dengan lebih cepat, memiliki sedikit kecelakaan kerja, mengajukan sedikit keluhan dan menurunkan tingkat stress. Dengan demikian dapat dikatakan bahwa pegawai yang memperoleh kepuasan kerja yang tinggi, maka dalam bekerja yang biasanya dia menyelesaikan dua pekerjaan menjadi empat atau lebih pekerjaan yang terselesaikan dalam sehari karena dia memiliki kemampuan dalam beprestasi dengan sungguh-sungguh. Sehingga hal tersebut, tentu akan membuat kinerjanya tinggi.

Motivasi kerja adalah hasrat di dalam seseorang yang menyebabkan orang tersebut melakukan tindakan bekerja melakukan sesuatu ( Robert L. M, 2006), sedangkan menurut (Rivai, 2004), mengatakan bahwa motivasi kerja adalah serangkaian sikap dan nilai- nilai yang memengaruhi individu untuk mencapai hal yang spesifik sesuai dengan tujuan individu.

Menurut L.N Jewel (dalam Marliani, 2015), ciri-ciri karyawan yang memiliki motivasi kerja yang tinggi adalah bersaing dalam berprestasi, ingin segera mengetahui hasil konkret dari usaha, berorientasi pada masa akan datang, tidak suka membuang-buang waktu, mempunyai rasa tanggung jawab, percaya diri dan ulet dalam menjalankan tugas. Dengan demikian dapat dikatakan bahwa pegawai yang motivasi kerjanya tinggi, dalam bekerja dia bisa menyelesaikan pekerjaannya lebih dari hasil pekerjaannya sebelumnya karena dia mampu dan sungguh-sungguh dalam bekerja sehingga, hal tersebut akan membuat kinerjanya tinggi. 
Sedangkan ciri-ciri karyawan yang memiliki motivasi kerja yang rendah menurut L.N Jewel (dalam Marliani, 2015), adalah kemampuan dalam beprestasi rendah, cenderung tidak peduli dengan hasil pekerjaan yang dilakukan, tingkat aspirasi rendah, suka membuang-buang waktu, tidak bertanggung jawab, tidak percaya diri, dan tidak ulet dalam bekerja. Dengan demikian dapat dikatakan bahwa pegawai yang motivasi kerjanya rendah, dalam bekerja dia tidak mampu menghasilkan pekerjaan yang baik karena, dia tidak sungguh-sungguh dan merasa tidak mampu dalam bekerja. Sehingga hal tersebut, menimbulkan kinerjanya yang rendah.

Kepuasan kerja tinggi juga mempengaruhi motivasi kerja yang tinggi, maka kepuasan kerja harus ditingkatkan lebih baik dilihat dari salah satu ciri-ciri kepuasan kerja dan motivasi kerja yang menunjukan pencapaian prestasi kerja, memelajari tugas yang berhubungan dengan pekerjaan baru dengan lebih cepat, serta ingin segera mengetahui hasil konkret dari usaha.

Dengan demikian dapat dikatakan bahwa pegawai yang memiliki kepuasan kerja yang tinggi, maka dalam bekerja dia mampu menyelesaikan pekerjaan dan lebih mencapai pretasi kerja yang baik karena dia sungguh-sungguh dalam bekerja. Sehingga hal tersebut akan membuat motivasi kerjanya tinggi.

Fenomena kinerja yang belum maksimal di Dinas Kesehatan Kabupaten Tapanuli Utara dapat terlihat berdasarkan wawancara dan data dokumen berupa SKP (Sasaran Kerja Pegawai). Wawancara yang 
dilakukan pada salah satu pimpinan yang ada di Instansi dapat diungkapkan dari salah satu pimpinan yang mengatakan :

"Kinerja pegawai disini dikatakan belum memuaskan artinya, pekerjaan itu ada yang tidak tuntas dan pekerjaannya itu terselesaikan setengah - setengah oleh Pegawainya sendiri. Itu dikarenakan, Pegawainya merasa tidak mampu menyelesaikan pekerjaan itu dan suka membuang-buang waktu, Pegawainya tidak taat dalam bekerja dan menunjukan kinerja yang belum maksimal. Dimana, seharusnya Pegawai itu mengharapkan nilai yang sempurna dengan predikat sangat baik, baru dapat dikatakan menunjukan kinerja yang maksimal apalagi diera zaman sekarang, kinerja itu harus menunjukan predikat kinerja yang sangat baik"

(Pada tanggal 21 April 2017).

Meninjau ungkapan hasil wawancara diatas dari salah satu pimpinan di instansi Dinas Kesehatan, bahwa menurunnya kinerja pada Pegawai Negeri Sipil adanya ketidaktaatan Pegawai dalam bekerja, kurang mampu menguasai pekerjaan yang diberikan serta pegawai yang tidak bisa hadir dihari itu juga untuk menyelesaikan pekerjaan dengan secepatnya. Sebagaimana menurut Handoko (2000), kinerja itu merupakan ukuran terakhir keberhasilan seorang Pegawai dalam melaksanakan pekerjaannya. Hal ini memperlihatkan kinerja itu tercapai apabila pekerjaan Pegawai terselesaikan dengan baik dan diimbangi dengan keberhasilan.

Dokumen yang didapat berupa SKP (Sasaran Kerja Pegawai) dari salah satu Pegawai Dinas Kesehatan, masih menunjukan penurunan kinerja pada 50 orang Pegawai dari 86 orang Pegawai dan masih menunjukan adanya kinerja yang belum maksimal. Dimana, Pegawai itu mengharapkan nilai yang sempurna dengan predikat "sangat baik" baru dapat dikatakan menunjukan kinerja yang maksimal. 
Memang secara kategorial dari data yang didapat, kinerja setiap pegawai menunjukan "Baik", tetapi dari segi angka pencapaian berubah menjadi menurun dan bukan dalam klasifikasi.

Berdasarkan uraian diatas, maka penulis tertarik untuk mengetahui bahwa kepuasan kerja dan motivasi kerja memiliki hubungan yang erat dengan kinerja seorang pegawai terhadap Instansinya. Untuk menguji kebenaran hal ini, perlu diadakannya penelitian secara empiris, oleh karena itu penulis tertarik melakukan penelitian dengan judul " Hubungan Kepuasan Kerja dan Motivasi Kerja dengan Kinerja Pegawai Negeri Sipil Pada Dinas Kesehatan Kabupaten Tapanuli Utara “.

\section{B. Identifikasi Masalah}

Adapun identifikasi masalah yang berkaitan dengan kinerja yang terjadi di Dinas Kesehatan Kabupaten Tapanuli Utara, yaitu : kurang mampu menguasai pekerjaan yang diberikan dengan bidangnya masingmasing serta adanya Pegawai Negeri Sipil yang suka membuang-buang waktunya dengan tidak bisa hadir dihari itu juga untuk menyelesaikan pekerjaan yang ingin segera diselesaikan dengan secepatnya. Sehingga, Pegawai akan memperlihatkan ketidak taatan Pegawai Negeri Sipil dalam bekerja tidak tuntas oleh karena itu, akan menimbulkan kinerja yang rendah pada Pegawai. 


\section{Batasan Masalah}

Adapun batasan masalah dalam penelitian ini adalah mengenai: hubungan kepuasan kerja dan motivasi kerja dengan kinerja Pegawai Negeri Sipil pada Dinas Kesehatan Kabupaten Tapanuli utara

\section{Rumusan Masalah}

Adapun rumusan masalah dalam penelitian ini adalah : "Apakah ada hubungan kepuasan kerja dan motivasi dengan kinerja Pegawai Negeri Sipil di Dinas Kesehatan Kabupaten Tapanuli Utara?

\section{E. Tujuan Penelitian}

Tujuan dari penelitian ini adalah untuk mengetahui:

1. Hubungan kepuasan kerja dengan kinerja Pegawai di Dinas Kesehatan Kabupaten Tapanuli Utara

2. Hubungan motivasi kerja dengan kinerja Pegawai di Dinas Kesehatan Kabupaten Tapanuli Utara

3. Hubungan kepuasan kerja dan motivasi kerja dengan kinerja Pegawai di Dinas Kesehatan Kabupaten Tapanuli Utara. 
F. Manfaat Penelitian

Adapun manfaat penelitian ini, ada dua manfaat yaitu :

1. Manfaat Teoritis

Penelitian ini diharapkan dapat memberikan wawasan dalam bidang ilmu psikologi, khususnya Psikologi Industri dan Organisasi, Dinas Kesehatan Kabupaten Tapanuli Utara dan Instansi lainnya.

2. Manfaat Praktis

Hasil penelitian ini diharapkan, dapat memberikan wawasan dan masukan kepada Pegawai yang bekerja diberbagai dan juga bagi Dinas Kesehatan Kabupaten Tapanuli Utara. 


\section{BAB II}

\section{TINJAUAN PUSTAKA}

\section{A. Pegawai Negeri Sipil ( Aparatur Sipil Negara )}

1. Pengertian PNS (Pegawai Negeri Sipil atau ASN (Aparatur Sipil Negara)

Berdasarkan Undang-undang Nomor 5 Tahun 2014, disebutkan beberapa pengertian terkait Aparatur Sipil Negara yaitu :

(a). Aparatur Sipil Negara adalah profesi bagi Pegawai Negeri Sipil dan pemerintah dengan perjanjian kerja yang bekerja pada Instansi pemerintahan.

(b). Aparatur Sipil Negara adalah Pegawai Negeri Sipil dan Pegawai Pemerintahan dengan perjanjian kerja yang diangkat ole pejabatpembina kepegawaian dan diserahi tugas dalam suatu jabatan Pemerintahan atau diserahi tugas Negara lainnya dan digaji berdasarkan peraturan perundangan - undangan

(c). PNS (Pegawai Negeri Sipil) adalah warga Negara Indonesia yang memenuhi syarat tertentu, diangkat sebagai pegawai ASN (Aparatur Sipil Negara) secara tetap oleh pejabat Pembina Kepegawaian untuk menduduki jabatan pemerintahan.

Berdasarkan uraian diatas dapat disimpulkan bahwa Pegawai Negeri Sipil yang disebut sekarang sebagai Aparatur Sipil Negara adalah profesi bagi warga Negara Sipil Pemerintahan yang bekerja pada Instansi pemerintahan untuk menduduki jabatan pemerintahan 
2. Fungsi Pegawai ASN (Aparatur Sipil Negara)

Berdasarkan Undang-undang Nomor 5 Tahun 2014 BAB IV Pasal 10, bahwa Pegawai ASN berfungsi sebagai:

a. Pelaksana kebijakan publik

b. Pelayan publik

c. Perekat dan pemersatu bangsa

Fungsi lain dari Aparatur Sipil Negara yaitu perwujudan tugas kepemerintahan dibidang tertentu yang dilaksanakan dalam rangka mencapai tujuan pembangunan nasional.

Berdasarkan fungsi Pegawai Aparatur Sipil Negera diatas, dapat disimpulkan bahwa pelaksana kebijakan publik, pelayan publik serta perekat dan pemersatu bangsa.

3. Tugas Pegawai ASN (Aparatur Sipil Negara)

Tugas pokok dari sebuah jabatan atau organisasi dari Aparatur Sipil Negara memberikan gambaran tentang ruang lingkup atau kompleksitas jabatan atau organisasi tersebut.

Berdasarkan Undang-undang Nomor 5 Tahun 2014 BAB IV Pasal 11, bahwa Pegawai ASN bertugas :

a. Melaksanakan kebijakan publik yang dibuat oleh Pejabat Pembina Kepegawaian sesuai dengan ketentuan peraturan perundang-undangan

b. Memberikan pelayanan publik yang professional dan berkualitas

c. Mempercepat persatuan dan kesatuan Negara Republik Indonesia 
Berdasarkan penjelasan tentang tugas Pegawai Aparatur Sipil Negara diatas, dapat disimpulkan bahwa tugasnya Aparatur Sipil Negara adalah melaksanakan kebijakan publik, memberikan pelayanan publik serta mempercepat persatuan dan kesatuan Negara Republik Indonesia

4. Peran Pegawai ASN (Aparatur Sipil Negara)

Berdasarkan Undang-undang Nomor 5 Tahun 2014 BAB IV Pasal 12, bahwa peran Pegawai ASN (Aparatur Sipil Negara) berperan sebagai perencana, pelaksana dan pengawas penyelenggaraan tugas umum pemerintahan dan pembangunan nasional melalui pelaksanaan kebijakan dan pelayanan publik yang professional, bebas dari intervensi politik, serta bersih dari praktik korupsi, kolusi, dan nepotisme .

Berdasarkan uraian diatas, dapat disimpulkan bahwa peran sebagai Pegawai Negeri Sipil atau yang sebutannya sekarang adalah Aparatur Sipil Negara adalah sebagai perencana, pelaksana, dan pengawas penyelenggara tugas umum pemerintahan dan pembangunan nasional.

\section{B. Kinerja}

1. Pengertian Kinerja

Selain memperhatikan Pegawai Negeri Sipil sebagai tenaga kerja, Instansi juga berusaha meningkatkan hasil kerja para Pegawainya dan hasil kerja Pegawai inilah yang disebut sebagai kinerja Pegawai. Menurut (Colquitt, 2011 ), bahwa kinerja adalah nilai dari seperangkat perilaku Pegawai yang berkontribusi, baik secara positif atau negative terhadap 
pemenuhan tujuan organisasi. Demikian halnya (Ivancevich, 2012), mengatakan kinerja adalah hasil yang dicapai dari apa yang diinginkan oleh organisasi.

Kinerja Pegawai (prestasi kerja) adalah hasil kerja secara kualitas dan kuantitas yang dicapai oleh seorang Pegawai dalam melaksanakan tugasnya sesuai dengan tanggung jawab yang diberikan kepadanya (A.A Anwar Prabu Mangkunegara, 2013). Sedangkan menurut (Handoko, 2000), kinerja adalah ukuran terakhir keberhasilan seorang Pegawai dalam melaksanakan pekerjaannya. Menurut Robbins (2013) mengatakan bahwa kinerja sebagai fungsi dari interaksi antara kemampuan atau ability (A), motivasi $(\mathrm{M})$, dan kesempatan atau opportunity $(\mathrm{O})$; yaitu kinerja $=\mathrm{f}$ $(\mathrm{AxMxO})$, artinya kinerja merupakan fungsi dari kemampuan, motivasi, dan kesempatan

Berdasarkan berbagai pengertian mengenai kinerja di atas, dapat disimpulkan bahwa kinerja adalah ukuran terakhir keberhasilan seorang pegawai melaksanakan pekerjaannya dengan nilai dari seperangkat hasil kerja dan perilaku baik yang positif ataupun yang negative sesuai dengan tanggung jawab yang diberikan kepadanya.

2. Faktor-faktor yang mempengaruhi kinerja

Menurut Robbin (Dalam Kasmir, 2016), menyatakan faktor-faktor yang memengaruhi kinerja baik hasil perilaku kerja adalah: 
1). Kemampuan dan keahlian

Pegawai yang memiliki kemampuan dan keahlian yang lebih baik, maka akan memberikan kinerja baik pula, demikian pula sebaliknya bagi pegawai yang tidak memiliki kemampuan untuk menyelesaikan pekerjaannya secara benar, maka akan memberikan hasil yang kurang baik. Dengan demikian kemampuan dan keahlian akan memengaruhi kinerja seseorang.

2). Kepribadian

Pegawai yang memiliki kepribadian atau karakter yang baik, akan dapat melakukan pekerjaan secara sungguh-sungguh penuh tanggung jawab sehingga, hasil pekerjaannya baik. Demikian pula sebaliknya bagi Pegawai yang memiliki kepribadian atau karakter yang buruk, akan bekerja secara tidak sungguh-sungguh dan kurang bertanggung jawab dan pada akhirnya hasil pekerjaannya pun tidak atau kurang baik dan tentu saja akan mempengaruhi kinerja yang ikut buruk pula. Artinya bahwa kepribadian atau karakter akan memengaruhi kinerja.

3) Kepuasan kerja

Merupakan perasaan senang atau gembira, atau perasaaan suka seseorang sebelum dan setelah melakukan suatu pekerjaan. Jika pegawai merasa senang atau gembira atau suka bekerja, maka hasil pekerjaannya pun akan berhasil baik. Demikian pula jika seorang pegawai tidak senang atau gembira dan tidak suka atas pekerjaannya, maka akan ikut 
memengaruhi hasil kerja Pegawai. Jadi dengan demikian, kepuasan kerja dapat memengraruhi kinerja.

4) Motivasi kerja

Motivasi kerja merupakan dorongan bagi seseorang untuk melakukan pekerjaan. Jika Pegawai memiliki dorongan yang kuat dari dalam dirinya atau dorongan dari luar dirinya (misalnya dari pihak perkantoran), maka Pegawai akan terangsang atau terdorong untuk melakukan sesuatu yang baik. Semakin termotivasi seseorang untuk melakukan suatu pekerjaan maka kinerjanya akan meningkat, demikian pula sebaliknya semakin tidak termotivasi seseorang untuk melakukan pekerjaannya, maka kinerjanya akan turun.

5) Lingkungan kerja

Merupakan susana atau kondisi disekitar lokasi tempat bekerja. Lingkungan kerja dapat berupa ruangan, layout, sarana dan prasarana, serta hubungan kerja dengan sesama rekan kerja. Jika lingkungan kerja dapat membuat suasana nyaman dan memberikan ketenangan makan akan membuat suasana kerja menjadi kondusif, sehingga dapat meningkatkan hail kerja seseorang menjadi lebih baik, karena bekerja tanpa gangguan. Namun sebaliknya, jika suasana atau kondisi lingkungan kerja tidak memberikan kenyamanan atau ketenangan, maka akan berakibat suasana kerja menjadi terganggu yang pada akhirnya akan memengaruhi dalam bekerja. Dengan demikian, dapat dikatakan bahwa lingkungan kerja memengaruhi kinerja seseorang. 
6) Komitmen

Merupakan kepatuhan pegawai untuk menjalankan kebijakan atau peraturan perusahaan dalam bekerja. Komitmen juga diartikan kepatuhan Pegawai untuk menjalankan kesepakatan yang telah dibuat. Dengan mematuhi janji atas kesepakatan tersebut membuatya berusaha untuk bekerja dengan baik dan merasa bersalah jika tidak dapat menepati janji atau kesepakatan yang telah dibuatnya. Pada akhirnya, kepatuhannya untuk melaksanakan janji atau kesepakatan yang telah dibuatnya akan memengaruhi kinerjanya. Jadi komitmen dapat memengaruhi kinerja seorang pegawai.

7) Disiplin Kerja

Merupakan usaha Pegawai untuk menjalankan aktivitas kerjanya secara sungguh-sungguh. Disiplin kerja dalam hal ini dapat berupa waktu, misalnya masuk kerja selalu tepat waktu. Kemudian disiplin dalam mengerjakan apa yang diperintahkan kepadanya sesuai dengan perintah yang harus dikerjakan. Pegawai yang disiplin akan memengaruhi kinerja.

Kemudian menurut (Robert L. Mathis, 2014) faktor-faktor yang memengaruhi kinerja, yaitu : kemampuan, motivasi, dukungan yang diterima, keberadaan pekerjaan yang dilakukan, hubungan Pegawai dan organisasi.

Menurut Robbin (2015), bahwa kinerja seseorang sangat dipengaruhi oleh faktor : kemampuan atau ability (A), motivasi atau motivation (M), dan kesempatan atau opportunity $(\mathrm{O})$. 
Dari pendapat diatas dapat disimpulkan faktor-faktor yang memengaruhi kinerja adalah kemampuan dan keahlian, kepuasan kerja dan motivasi kerja, lingkungan kerja, komitmen, disiplin kerja.

\section{Penilaian Kinerja}

Menurut Peraturan Pemerintahan (Nomor 46 Tahun 2011) tentang penilaian prestasi kerja Pegawai Negeri Sipil, bahwa Penilaian prestasi kerja Pegawai Negeri Sipil dilaksanakan secara sistematis yang penekanannya pada tingkat capaian sasaran kerja Pegawai atau tingkat capaian hasil kerja yang telah disusun dan disepakati bersama antara Pegawai Negeri Sipil dengan Pejabat Penilai.

Penilaian prestasi kerja Pegawai Negeri Sipil dilaksanakan oleh Pejabat Penilai sekali dalam 1 (satu) tahun yang dilakukan setiap akhir Desember pada tahun yang bersangkutan atau paling lama akhir Januari tahun berikutnya. Penilaian prestasi kerja Pegawai Negeri Sipil terdiri atas unsur : SKP dengan bobot nilai $60 \%$ dan perilaku kerja dengan bobot nilai $40 \%$.

Penilaian prestasi kerja Pegawai Negeri Sipil dilakukan berdasarkan prinsip objektif, terukur, akuntabel, partisipatif, dan transparan. Penilaian Prestasi kerja Pegawai Negeri Sipil terdiri atas unsur sasaran kerja Pegawai dan perilaku kerja. Sasaran kerja Pegawai yang selanjutnya disingkat SKP adalah rencana kerja dan target yang akan dicapai oleh Pegawai Negeri Sipil. 
Berdasarkan pendapat diatas, penilaian prestasi Pegawai terdiri atas unsur : SKP dengan bobot nilai $60 \%$ dan perilaku kerja dengan bobot nilai 40\%. Dilaksanakan oleh Pejabat Penilai sekali dalam 1 (satu) tahun yang dilakukan setiap akhir Desember pada tahun yang bersangkutan atau paling lama akhir Januari tahun berikutnya serta dilakukan berdasarkan prinsip objektif, terukur, akuntabel, partisipatif, dan transparan

4. Aspek-aspek yang dinilai dalam ukuran prestasi kerja Pegawai (SKP)

Menurut Peraturan Pemerintahan (Nomor 46 Tahun 2011) tentang penilaian prestasi kerja Pegawai Negeri Sipil , beberapa aspek-aspek penilaian prestasi kerja sebagai berikut :

1. Kuantitas (Output)

Dalam menentukan Target Output (TO) dapat berupa dokumen, konsep, naskah, surat keputusan, paket, laporan, dan lain - lain.

2. Kualitas (Target Kualitas)

Dalam menetapkan Target Kualitas (TK) harus memprediksi pada mutu hasil kerja yang terbaik, target kualitas diberikan nilai paling tinggi 100 (seratus).

3. Waktu (Target Waktu)

Dalam penetapan target waktu (TW) harus memperhitungkan beberapa waktu yang dibutuhkan untuk menyelesaikan suatu pekerjaan, misalnya bulanan, triwulan, kwartal, semester, dan tahunan 
4. Biaya (Target Biaya)

Dalam menetapkan Target Biaya (TB) harus memperhitungkan berapa biaya yang dibutuhkan untuk menyelesaikan suatu pekerjaan dalam 1 (satu) tahun, misalnya jutaan, ratusan juta, miliaran, dan lain - lain.

Perilaku terhadap organisasi/lembaga atau atasandan juga rekan kerja. Sedangkan menurut (Kasmir, 2016), Aspek-aspek penilaian prestasi kerja sebagai berikut :

1. Kualitas (mutu)

Merupakan suatu tingkatan dimana proses atau hasil dari penyelesaian suatu kegiatan mendekati titik kesempurnaan. Semakin sempurna pekerjaan yang terselesaikan, maka kinerja semakin baik, demikian pula sebaliknya jika kualitas pekerjaan yang dihasilkan rendah, maka kinerjanya juga rendah. Dalam praktiknya kualitas suatu pekerjaan dapat dilihat dalam nilai tertentu.

2. Kuantitas (jumlah)

Merupakan produksi yang dihasilkan dapat ditunjukan dalam bentuk satuanmata uang, jumlah unit,atau jumlah siklus kegiatan yang diselesaikan. Biasanya untuk pekerjaan tertentu sudah ditentukan kuantitas yang dicapai dan kuantitas yang diharapkan adalah jumlah sesuai dengan target atau melebihi dari target yang telah ditetapkan.

3. Waktu (jangka waktu)

Untuk jenis pekerjaan diberikan batas waktu dalam menyelesaikan pekerjaannya. Artinya ada pekerjaan batas waktu minimal dan maksimal 
yang harus dipenuhi (misalnya 30 menit). Yang artinya itu semua ketepatan waktu merupakan dimana kegiatan tersebut dapat diselesaikan, atau suatu hasil produksi dapat dicapai dengan batas waktu yang telah ditetapkan sebelumnya. Dengan kata lain,untuk jenis pekerjaan tertentu semakin cepat suatu pekerjaan terselesaikan, semakin baik kinerjanya demikian pula sebaliknya.

4. Penekanan Biaya

Biaya yang dikeluarkan untuk setiapaktivitas perkantoran sudah dianggarkan sebelum aktivitas dijalankan. Artinya dengan biaya yang sudah dianggarkan tersebut merupakan acuan agar tidak melebihi dari yang sudah dianggarkan. Jika pengeluaran biaya melebihi anggaran yang telah ditetapkan makan akan terjadi pemborosan, sehingga kinerjanya dianggap kurang baik demikian pula sebaliknya.

5. Pengawasan

Dengan melakukan pengawasan pegawai akan merasa lebih bertanggung jawab atas pekerjaannya dan jika terjadi penyimpangan akan memudahkan untuk melakukan koreksi dan melakukan perbaikan secepatnya. Artinya, pengawasan sangat diperlukan dalam rangka mengendalikan aktivitas Pegawai agar tidak meleset dari yang sudah direncanakan atau ditetapkan.

6. Hubungan antar Pegawai

Dalam hubungan ini diukur apakah seorang Pegawai mampu untuk mengembangkan perasaan saling menghargai, niat baik dan kerja sama antara Pegawai yang satu dengan pegawai yang lain. Hubungan antara 
perseorangan akan menciptakan suasana yang nyaman dan kerja sama yang memungkinkan satu sama lain saling mendukung untuk menghasilkan aktivitas pekerjaan yang lebih baik. Hubungan antar Pegawai ini merupakan perilaku kerja yang dihasilkan seorang Pegawai.

Berdasarkan penjelasan mengenai indikator-indikator diatas, dapat disimpulkan bahwa aspek-aspek ataupun target yang digunakan sebagai ukuran prstasi kerja Pegawai Negeri Sipil adalah kuantitas, kualitas, waktu, dan biaya

\section{Kepuasan Kerja}

1. Pengertian Kepuasan Kerja

Banyak ahli mendefinisikan tentang kepuasan kerja, diantaranya adalah (Colquitt, LePine, Wesson, 2011), menyatakan bahwa kepuasan kerja adalah tingkat perasaan menyenangkan yang diperoleh dari penilaian pekerjaan seseorang atau pengalaman kerja. Dengan kata lain, kepuasan kerja mencerminkan bagaimana kita merasakan tentang pekerjaan kita dan apa yang kita pikirkan tentang pekerjaan kita. Kepuasan kerja menunjukan adanya kesesuaian antara harapan seseorang yang timbul dengan imbalan yang disediakan oleh pekerjaan (Luthan, 1995). Robbins (1996), mengatakan bahwa kepuasan kerja merupakan sikap umum seorang karyawan terhadap pekerjaannya. Pendapat lainnya menurut (McShane dan Von Glinow, 2010), memandang kepuasan kerja sebagai evaluasi seseorang atas pekerjaannya dan konteks pekerjaan. Merupakan penilaian 
terhadap karateristik pekerjaan, lingkungan kerja, dan pengalaman emosional di pekerjaan yang dirasakan. Sedangkan menurut (Robbins 2011), bahwa kepuasan kerja adalah perasaan positif tentang pekerjaan sebagai hasil evaluasi dari karakteristiknya.

Berdasarkan pengertian tersebut dapat disimpulkan bahwa pada hakikatnya kepuasan kerja merupakan tingkat perasaan senang seseorang sebagai penilaian positif terhadap pekerjaannya dan lingkungan tempat pekerjaannya.

2. Aspek-aspek Kepuasan Kerja

Terdapat beberapa aspek kepuasan kerja seseorang terhdap kepuasan suatu pekerjaan, dimana beberapa aspek tersebut menurut Robbins (dalam Ali, 2011) adalah :

a) Menarik tidaknya pekerjaan yang dilakukan oleh pekerja. Dalam hal ini, karyawan cenderung menyukai pekerjaan yang memberi kesempatan kepada mereka untuk dapat menunjukan keterampilan dan kemampuan mereka, serta menawarkan beragam tugas. Dengan demikian mereka akan menunjukan begitu baiknya mereka mengerjakan suatu pekerjaan.

b) Ganjaran yang pantas. Meliputi jumlah kompensasi yang diterima dan kesempatan untuk promosi jabatan. Dalam melakukan pekerjaannya, para karyawan menginginkan imbalan yang sesuai dengan apa yang telah mereka kerjakan. Imbalan yang dimaksud disini adalah imbalan yang berupa kompensasiatas gaji atau upah yang seharusnya diterima. 
Sedangkan promosi merupakan bentuk lain dari imbalan yang diberikan perusahaan kepada karyawan.

c) Dukungan rekan sekerja dan kemampun atasan dalam memberikan bantuan teknis dan bantuan perilaku. Dalam bekerja seorang pekerja tidak hanya sekedar mencari materi (nafkah), tetapi mereka juga mempunyai kebutuhan untuk berinteraksi sosial dengan pekerja yang lain. Interaksi ini akan menimbulkan kepuasan kerja apabila antara pekerja yang satu dengan pekerja yang lain terdapat hubungan yang baik, misalnya rekan kerja yang ramah, memiliki toleransi dan kompak.

d) Kondisi kerja yang mendukung. Kebanyakan karyawan yang bekerja secara optimal apabila lingkungan kerja mereka mendukung, dalam artian bahwa fasilitas di liingkungan tempat mereka bekerja memadai dan nyaman.

Aspek-aspek kepuasan kerja menurut Hackman \& Oldman (dalam Wexley \& Yukl, 1992), adalah :

a. Pekerjaan itu sendiri, aspek ini mencakup minat, perhatian, kreativitas, pengakuan, dan rasa yang dimiliki pegawai terhadap Instansi

b. Lingkungan pekerjaan, aspek ini mencakup struktur organisasi, sistem imbalan, rasa aman dalam bekerja, lokasi, situasi, dan kondisi kerja, serta status dalam bekerja. 
c. Kebutuhan individu, aspek ini mencakup waktu istirahat pegawai, hubungan sosial antar pegawai dalam Instansi, lama waktu bekerja, dan penentuan waktu kerja.

Gibson (1996) mengatakan aspek - aspek yang memengaruhi kepuasan kerja yaitu : upah, pekerjaan, promosi, penyelia, dan rekan kerja. Sedangkan menurut Robbins (1996), menyebutkan bahwa aspek - aspek kerja yang memengaruhi kepuasan kerja adalah upah, pekerjaan, promosi, penyelia, dan rekan kerja.

Dari pendapat diatas dapat disimpulkan bahwa aspek-aspek kerja yang berpengaruh terhadap kepuasan kerja adalah menarik tidaknya pekerjaan itu, ganjaran yang pantas, dukungan rekan sekerja, kondisi kerja, pekerjaan itu sendiri, lingkungan kerja dan kebutuhan individu dalam bekerja.

3. Ciri-ciri karyawan yang memiliki Kepuasan kerja dan ketidakpuasan kerja Kepuasan kerja yang rendah akan mengakibatkan tingkat ketidakhadiran yang tinggi, terjadinya turnover, rendahnya produktivitas kerja, tidak tercapainya prestasi, keputusan untuk melakukan pensiun dini, kesehatan mental dan fisik menurun hingga merasakan ketidakpuasan dalam hidup, menurut Aydogdu (dalam Alamsyah, 2015). Sedangkan Menurut Luthans (dalam Alamsyah, 2015), Kepuasan kerja yang tinggi tentunya akan memberikan dampak yang jauh lebih baik dan menguntungkan bagi perkantoran dilihat dari tingkat kepuasan pegawai yang tinggi cenderung memiliki pecapaian prestasi kerja, kesehatan fisik 
yang lebih baik, memelajari tugas yang berhubungan dengan pekerjaan baru dengan lebih cepat, memiliki sedikit kecelakaan kerja, mengajukan sedikit keluhan dan menurunkan tingkat stress.

Berdasarkan uraian diatas bahwa ciri-ciri pegawai yang memiliki kepuasan kerja yang tinggi pegawai menunjukan dampak yang lebih menguntungkan dilihat dari mengerjakan pekerjaan baru dengan lebih cepat terselesaikan sedangkan pegawai yang memiliki ciri kepuasan kerja yang rendah akan menimbulkan rendahnya produktivitas kerja, tidak tercapainya prestasi, keputusan untuk melakukan pensiun dini, kesehatan mental dan fisik menurun hingga merasakan ketidakpuasan dalam hidup.

4. Faktor-faktor yang mempengaruhi kepuasan kerja

Faktor-faktor yang menentukan kepuasan kerja menurut Robbins (dalam Ali, 2011) adalah :

a) Kerja yang secara mental mendukung

Karyawan lebih cenderung menyukai pekerjaan-pekerjaan yang memberi mereka kesempatan untuk menggunakan keterampilan dan kemampuan mereka dan menawarkan beragam tugas, kebebasan, dan umpan balik mengenai betapa baik mereka mengerjakan.

b) Ganjaran yang pantas

Karyawan yang cenderung menginginkan sistem upah dan kebijakan promosi yang mereka persepsikan adil sesuai harapan mereka. 
c) Kondisi kerja yang mendukung

Karyawan lebih menyukai lingkungan kerja yang baik untuk kenyamanan pribadi maupun untuk memudahkan mengerjakan tugas pekerjaan.

d) Rekan kerja yang mendukung

Seorang karyawan tidak hanya mempunyai kebutuhan akan uang dan prestasi saja, karyawan juga mempunyai kebutuhan untuk berinteraksi dengan orang lain atau karyawan lain.

e) Kesesuaian kepribadian dan pekerjaan

Karakteristik kepribadian seorang karyawan yang sesuai dengan karakteristik pekerjaannya akan dapat membuat seorang karyawan lebih merasa puas terhadap pekerjaannya.

Ada 5 faktor penentu kepuasan kerja yang disebut dengan Job Descriptive Index (JDI) menurut Luthans (dalam Yusmanita, 2013) yaitu :

1. Pekerjaan itu sendiri

Tingkat dimana sebuah pekerjaan menyediakan tugas yang menyenangkan, kesempatan belajar dan kesempatan untuk mendapatkan tanggung jawab

\section{Gaji}

Sejumlah upah yang diterima dan tingkat dimana hal ini dipandang sebagai hal yang dianggap pantas dibandingkan dengan orang lain dalam organisasi. 
3. Kesempatan promosi

Karyawan memiliki kesempatan untuk mengembangkan diri dan memperluas pengalaman kerja, dengan terbukanya kesempatan untuk kenaikan jabatan

4. Pengawasan

Kemampuan penyelia untuk memberikan bantuan teknis dan dukungan perilaku

5. Rekan kerja

Kebutuhan dasar manusia untuk melakukan hubungan sosial akan terpenuhi dengan adanya rekan kerja yang mendukung karyawan. Jika terjadi konflik dengan rekan kerja, maka akan berpengaruh pada tingkat kepuasan karyawan terhadap pekerjaan

Menurut Riva'i (dalam Ali, 2011), kepuasan kerja dipengaruhi oleh dua faktor, antara lain :

a) Faktor Intrinsik

Faktor intrinsik merupakan faktor yang berasal dari dalam diri pegawai dan dibawa oleh setiap Pegawai sejak mulai bekerja di tempat kerjanya.

b) Faktor ekstrinsik

Faktor ekstrinsik menyangkut hal-hal yang berasal dari luar diri Pegawai yang antara lain terdiri dari kondisi fisik lingkungan kerja, interaksinya dengan Pegawai lain, dan sistem penggajian. 
Berdasarkan penjelasan diatas dapat disimpulkan bahwa faktor yang menentukan kepuasan kerja adalah faktor intrinstik dan ekstrinsik serta yang salah satunya ada kondsi kerja dan rekan kerja yang mendukung.

5. Jenis-jenis Kepuasan kerja

Menurut Hasibuan (2000), Kepuasan Kerja dapat dibedakan menjadi tiga jenis yaitu :

a. Kepuasan kerja di dalam pekerjaan

Kepuasan kerja di dalam pekerjaan merupakan kepuasan kerja yang dinikmati dalam pekerjaan dengan memperoleh pujian hasil kerja, penempatan, perlakuan, peralatan, dan suasana lingkungan kerja yang baik. Pegawai yang lebih suka menikmati kepuasan kerja dalam pekerjaan akan lebih mengutamakan pekerjaannya dari pada balas jasa walaupun balas jasa itu penting.

b. Kepuasan kerja diluar pekerjaan

Kepuasan diluar pekerjaan adalah kepuasan kerja Pegawai yang di nikmati diluar pekerjaannya dengan besarnya balas jasa yang akan diterima dari hasil kerjanya. Balas jasa atau kompensasi digunakan pegawai tersebut untuk mencukupi kebutuhan-kebutuhannya.

Pegawai yang lebih menikmati kepuasan kerja diluar pekerjaan lebih memperhatikan balas jasa dari pada pelaksanaan tugas-tugasnya. Pegawai akan merasa puas apabila mendapatkan imbalan yang besar. 
c. Kepuasan kerja kombinasi dalam dan luar pekerjaan.

Kepuasan kerja kombinasi dalam dan luar pekerjaan merupakan kepuasan kerja yang dicerminkan oleh sikap emosional yang seimbang antar balas jasa dengan pelaksaan pekerjaannya.

Pegawai yang lebih menikmati kepuasan kerja kombinasi dalam dan diluar pekerjaan ini, akan merasa puas apabila hasil kerja dan balas jasa dirasanya adil dan layak.

Berdasarkan uraian diatas, kepuasan kerja dibedakan menjadi tiga macam kepuasan kerja yang didasarkan pada bagaimana dan dimana kepuasan kerja tersebut dirasakan atau dinimati. Ketiga jenis kepuasan kerja tersebut adalah kepuasan kerja yang dinikmati di dalam pekerjaan, kepuasan kerja yang dinikmati di luar pekerjaan, dan kombinasi kepuasan kerja di dalam dan di luar pekerjaan.

\section{Motivasi Kerja}

1. Pengertian Motivasi Kerja

Menurut Robert L. Mathis (2001), motivasi kerja sebagai hasrat di dalam seseorang yang menyebabkan orang tersebut melakukan tindakan bekerja melakukan sesuatu. Robbin (2003), mengatakan motivasi kerja adalah keinginan untuk berusaha sekuat tenaga untuk mencapai tujuan organisasi yang dikondisikan atau ditentukan oleh kemampuan usaha untuk memenuhi suatu kebutuhan individu. Sedangkan menurut Merihot (2003), mendefinisikan motivasi kerja sebagai faktor-faktor yang mengarahkan dan 
mendorong perilaku atau keinginan seseorang untuk melakukan suatu kegiatan yang dinyatakan dalam bentuk usaha yang keras. Motivasi kerja adalah sekumpulan kekuatan energetik yang dimulai baik dari dalam maupun diluar pekerja, dimulai dari usaha yang berkaitan dengan pekerjaan, dan mempertimbangkan arah, intensitas dan ketekunannya. Sedangkan menurut Luthan (1995), bahwa motivasi kerja adalah proses sebagai langkah awal seseorang melakukan tindakan akibat kekurangan secara fisik dan psikis atau dengan kata lain adalah suatu dorongan yang ditunjukan untuk memenuhi tujuan tertentu.

Dari pengertian diatas, dapat disimpulkan bahwa motivasi kerja adalah dorongan individu untuk melakukan tindakan terhadap serangkaian proses perilaku manusia dengan mempertimbangkan arah, intensitas, dan ketekunan karena, mereka ingin melakukan suatu pekerjaan yang dinyatakan dalam bentuk usaha yang keras dalam pencapaian tujuan yang mereka inginkan.

2. Faktor - faktor yang mempengaruhi Motivasi Kerja

Sesuai dengan pengertian motivasi kerja yakni segala sesuatu yang mendorong semangat untuk bekerja. Disamping itu mendorong orang untuk bekerja karena adanya kebutuhan yang harus dipenuhi. Dengan adanya kebutuhan inilah para pekerja berusaha keras utnuk mencapai kebutuhannya melalui pekerjaannya. Akan tetapi motivasi kerja orang dalam bekerja dipengaruhi oleh beberapa faktor (Handoko, 2000). 
Stoner dan Winkel (dalam Ali, 2011), mengatakan faktor-faktor yang mempengaruhi motivasi kerja adalah karakteristik individu, karakteristik pekerjaan dan karakteristik situasi kerja.

a. Karakteristik Individu, yaitu faktor-faktor yang ada dalam diri individu mempengaruhi motivasi kerja individu tersebut seperti minat, sikap dan kebutuhan yang dibawa seseorang ke dalam situasi kerja yang berbedabeda diantara individu yang satu dengan individu yang lain, dengan demikian motivasi orang di dalam melakukan pekerjaan juga berbeda.

b. Karakteristik Pekerjaan, yaitu pekerjaan itu sendiri yang mempengaruhi motivasi kerja seperti sifat dan tugas pegawai yang meliputi jumlah tanggungjawab juga macam tugas. Kondisi ini berperan dalam meningkatkan atau justru menurunkan motivasi kerja Pegawai.

c. Karakteristik Situasi Kerja, yaitu faktor-faktor lingkungan kerja yang mempengaruhi motivasi kerja seseorang, seperti apakah rekan kerja mendorong individu untuk bekerja dengan standar tinggi atau rendah.

Munandar (dalam Ardiyati, 2013), mengemukakan ada juga beberapa faktor yang dapat mempengaruhi motivasi kerja seseorang. Dimana seorang pemimpin dapat menerapkan teori motivasi dalam menggerakkan para Pegawai Negeri Sipil untuk dapat bekerja lebih baik. Beberapa faktor tersebut antara lain :

1. Usia

Berdasarkan penelitian dan pengalaman usia seseorang akan menunjukkan tingkat kepuasan karyawan dalam bekerja. Dimana 
kepuasan kerja yang cenderung tinggi didasarkan pada usaha meniti karir dalam sekian tahun lamanya yang dicapai secara maksimal. Sehingga manajer perlu mengadakan pendekatan yang berbeda dengan memberikan motivasi dalam bentuk perlakuan terhadap karyawan yang relatif muda dibandingkan dengan karyawan yang usianya sudah lebih tua.

2. Jenis Kelamin

Tidak terdapat perbedaan yang mencolok antara karyawan dan karyawati sepanjang kemampuan mereka menjadi anggota organisasi yang konstruktif dan kontributif. Namun selain dapat dilihat bahwa seorang laki-laki lebih termotivasi dalam bekerja, karena secara kodrati laki-laki merupakan kepala keluarga yang harus memberikan nafkah untuk istri dan anak-anaknya. Sedangkan seorang wanita bekerja sebagian besar hanya terdorong untuk beraktualisasi dan bersosialisasi.

\section{Status Perkawinan}

Seorang karyawan dan karyawati yang sudah berkeluarga akan cenderung lebih mudah merasa puas dalam pekerjaanya dibandingkan dengan orang yang belum berkeluarga, ini disebabkan oleh rasa tanggung jawab yang besar untuk menghidupi keluarganya. Sehingga dalam hal ini status perkawinan seseorang turut pula memberikan petunjuk tentang tata cara dan teknik motivasi yang cocok digunakan baginya dibandingkan dengan orang yang tidak berkeluarga. 
4. Jumlah Tanggungan

Jumlah tanggungan merupakan salah satu pengaru untuk seorang manajer dalam menerapkan teori motivasi dalam suatu perusahaan. Dalam masyarakat yang masih menganut konsep " extended family system ", dimana yang dianggap menjadi tanggungan seorang pencari nafkah utama keluarga adalah semua orang yang biaya hidupnya tergantung pada pencari nafkah utama tersebut, tidak terbatas hanya pada istri atau suami dan anak-anak.

5. Masa Kerja

Masa kerja merupakan salah satu indikator tentang kecenderungan para pekerja dalam berbagai segi kehidupan organisasional. Seorang manajer beranggapan bahwa semakin lama seseorang berkarya/ bekerja dalam suatu organisasi, semakin tinggi pula produktivitasnya karena ia semakin berpengalaman dan memiliki keterampilan dalam menyelesaikan tugas-tugas yang dipercayakan kepadanya. Sehingga keinginan manajer dan perusahaan untuk memberikan suatu motivasi terhadap para karyawannya dalam melakukan pekerjaannya dengan baik.

Menurut Siagian (dalam Yusmanita, 2013) faktor ini datang dari dalam diri karyawan yang menjadi pendorong seseorang untuk berprestasi dan lebih bersemangat dalam bekerja sehingga kinerjanya lebih baik dan pekerjaannya berkualitas, adapun faktor-faktor tersebut adalah : 
1. Tanggung jawab

Tanggung jawab akan mampu memberikan motivasi kepada karyawan untuk turut serta dalam pencapaian perusahaan. dengan pemberian tanggung jawab atas tugasnya, maka karyawan akan merasa senang jika hasil kerjanya sesuai dengan apa yang diminta dan diharapkan oleh atasannya.

2. Pencapaian prestasi

Pencapaian prestasi merupakan hal yang diharapkan baik oleh karyawan maupun organisasi. Jika seorang karyawan memiliki kemampuan yang lebih dari harapan organisasi maka perusahaan atau organisasi harus memberikan sesuatu pencapaian prestasi tersebut, misalnya dalam bentuk promosi

3. Pekerjaan itu sendiri

Pekerjaan yang sifatnya rutinitas dan sangat teknis tidak lagi menuntut adanya kreativitas, imajinasi, inovasi dalam pelaksanaannya. Hal ini merupakan salah satu sumber kejenuhan dan kebosanan, kondisi ini akan menimbulkan kelelahan tersendiri bagi karyawan akibatnya karyawan tidak memiliki semangat dan motivasi dalam bekerja

4. Pengakuan atas prestasi

Setiap individu memiliki keinginan untuk dihargai, bekerja bagi karyawan saat ini lebih dari sekedar mendapat gaji. Mereka ingin diperlakukan dan dihargai sebagai manusia dan kadang hal ini sering belum disadari oleh 
para manajer, penghargaan yang diperlukan akan memberikan tenaga dan motivasi baru bagi karyawan dalam melaksanakan tugas-tugasnya.

5. Perkembangan karir

Perkembangan karir adalah peningkatan-peningkatan pribadi yang dilakukan seseorang untuk mencapai suatu rencana karir maka semakin besar motivasi karyawan bersangkutan untuk bekerja dengan baik Sementara itu faktor pendorong yang datang dari luar diri karyawan itu sendiri adalah berupa faktor :

1. Kebijakan

2. Administrasi perusahaan

3. Pengawasan

4. Hubungan interpersonal

5. Kondisi kerja

6. Kompensasi

7. Status

8. Rasa aman

Seberapa banyak orang menikmati prestasi tergantung pada pengakuannya. Pada giliran kemampuan untuk mencapai terletak pada pekerjaan yang menyenangkan, semakin banyak individual yang merasakan kepuasan kemajuan, sebagai motivator adalah :

1. Prestasi

2. Pengakuan

3. Minat dan pekerjaan 
4. Tanggung jawab

5. Kemajuan

Faktor-faktor diatas merupakan kebutuhan utama oleh karena itu jika dapat terpenuhi akan dapat menjadi pendorong yang kuat bagi seseorang untuk bekerja lebih baik dan optimal menurut Wibowo (dalam Yusmanita, 2013)

Berdasarkan uraian diatas, dapat disimpulkan bahwa terdapat beberapa faktor yang mempengaruhi motivasi kerja adalah usia, jenis kelamin, status pernikahan, jumlah tanggungan, masa kerja.

3. Aspek-Aspek Motivasi Kerja

Menurut Jurgensen (dalam Ali, 2011) untuk mengungkapkan motivasi kerja harus memperhatikan aspek-aspek sebagai berikut :

a. Pekerjaan yang menimbulkan rasa aman, yaitu segala pekerjaan yang dilakukan dapat menimbulkan rasa aman bagi karyawan tersebut.

b. Perusahaan yang memberi rasa bangga terhadap karyawan, yaitu tempat dimana karyawan bekerja mempunyai nama baik.

c. Kesempatan untuk maju, yaitu kesempatan untuk promosi dan kesempatan untuk memperoleh pengalaman baru.

d. Kelompok kerja, yaitu teman sekerja yang dpat diajak kerja sama dalam melakukan pekerjaan.

e. Pekerjaan itu sendiri, yaitu pekerjaan yang sesuai dengan minat, bakat, pendidikan dan pengalaman.

f. Gaji, yaitu yang tinggi menurut karyawan. 
g. Hubungan antara atasan dan bawahan, yaitu gaya atasan terhadap bawahan dan atasan yang mempunyai hubungan baik dengan bawahannya.

h. Jaminan kerja, yaitu jam kerja yang sangat singkat atau jam kerja yang tidak terlalu lama.

i. Kondisi kerja, yaitu keadaan tempat kerja seperti pengaturan udara, suhu dan kebersihan tempat kerja.

j. Jaminan kesehatan, yaitu fasilitas tempat kerja seperti asuransi.

Menurut Herzberg (dalam Ali, 2011), mengatakan bahwa ada 2 aspek Motivasi kerja yang menyebabkan pegawai melakukan pekerjaan, kedua aspek dorngan Motivasi kerja tersebut adalah :

a. Aspek Intrinsik, yaitu faktor daya dorong yang timbul dari dalam diri masing-masing pegawai, berupa

1. Pekerjaan itu sendiri (the work it self). Berat ringannya tantangan yang dirasakan tenaga kerja dari pekerjaannya

2. Kemajuan (advancement). Besar kecilnya kemungkinan tenaga kerja berpeluang maju dalam pekerjaannya seperti naik pangkat.

3. Perkembangan (The Possibility of Growth). Besar kecilnya yang dirasakan atas kerja keras yang baik yang dilakukan seorang tenaga kerja.

4. Tanggung jawab (responsibility). Besar kecilnya yang dirasakan terhadap tanggung jawab diberikan kepada seorang tenaga kerja.

5. Pengakuan (recognition). Besar kecilnya pengakuan yang diberikan kepada tenaga kerja atas hasil kerja. 
6. Pencapaian (achievement). Besar kecilnya kemungkinan tenaga kerja mencapai prestasi kerja tinggi.

b. Aspek Ekstrinsik yaitu faktor pendorong yang datang dari luar diri seseorang terutama dari organisasi tempatnya bekerja. Aspek Ektrinsik ini mencakup :

1. Kebijakan dan Administrasi Perusahaan (Company Policy and Administration). Derajat kesesuaian yang dirasakan karyawan dari semua kebijakan dan peraturan yang berlaku dalam organisasi

2 Penyeliaan (Quality Supervisor). Tingkat kewajaran penyelia yang diterima dan dirasakan oleh tenaga kerja.

3 Gaji (Wages). Derajat kewajaran gaji yang diterima sebagai imbalan terhadap kinerjanya

4 Hubungan antar pribadi (Interpersonal Relation). Tingkat kesesuaian yang dirasakan dalam berinteraksi antar tenaga kerja yang lain.

5 Kondisi kerja (Working Condition). Tingkat kesesuaian kondisi kerja dengan pelaksanaan tugas pekerjaannya.

6. keamanan kerja (Work Security). Tingkat kesesuaian keamanan tempat kerjapada karyawan dalam bekerja dengan baik

Berdasarkan aspek-aspek motivasi kerja yang telah dikemukakan diatas, maka dapat disimpulkan bahwa aspek-aspek yang mempengaruhi motivasi kerja karyawan dalam organisasi terbagi dua bagian besar meliputi:

a. Aspek ekstrinsik, yaitu administrasi, penyelia, gaji, hubungan antar pribadi, kondisi kerja, keamanan kerja. 
b. Aspek intrinsik, yaitu pekerjaan itu sendiri, kemajuan, perkembangan, tanggung jawab, pengakuan, pencapaian

Kedua aspek motivasi kerja tersebut merupakan aspek-aspek pendorong timbulnya dan mempengaruhi motivasi kerja dan dipergunakan dalam pembuatan skala motivasi kerja dalam penelitian ini. Aspek-aspek motivasi kerja tersebut mempunyai pengaruh terhadap kinerja dan performansi Pegawai terhadap pekerjaan.

4. Cara Meningkatkan Motivasi Kerja

Menurut Munandar (2001) ada beberapa cara untuk meningkatkan motivasi kerja yaitu:

a. Peran pemimpin/atasan. Adanya sikap keras dan memberi tujuan yang bermakna.

b. Peran diri sendiri. Kepemimpinan transformasional dan transaksional dapat membantu tenaga kerja menjadi tenaga kerja dengan motivasi kerja yang proaktif.

c. Peran organisasi. Berbagai kebijakan dan peraturan dapat menarik atau mendorong motivasi kerja seorang tenaga kerja.

Berdasarkan poin cara meningkatkan motivasi kerja diatas dapat disimpulkan bahwa peran dari pimpinan, peran diri sendiri dan peran organisasi membantu Pegawai dalam meningkatkan motivasi kerja dalam melakukan pekerjaannya. 
5. Metode Motivasi Kerja

Menurut Suwatno (2001), metode motivasi kerja memiliki 2 metode, yaitu:

a. Motivasi Langsung (Direct Motivation)

Motivasi langsung adalah motivasi (materil dan non-materil) yang diberikan secara langsung kepada setiap individu Pegawai untuk memenuhi kebutuhan serta kepuasannya. Jadi sifat khususnya, seperti pujian, penghargaan, tunjangan hari raya, bonus, bintang jasa dan lain sebaginya.

b. Motivasi Tidak Langsung (Indirect Motivation)

Motivasi tidak langsung adalah motivasi yang diberikan hanya merupakan fasilitas-fasilitas yang mendukung serta menunjang gairah kerja/kelancaran tugas, sehingga para karyawan betah dan bersemangat melakukan pekerjaannya. Misalnya kusri yang empuk, mesin-mesin yang baik, ruangan kerja yang terang dan nyaman, suasana pekerjaan yang serasi, penempatan yang tepat dan lain sebagainya. Motivasi tidak langsung ini besar pengaruhnya untuk merangsang semangat bekerja Pegawai, sehingga produktifitas Instansi meningkat.

Berdasarkan uraian tersebut dapat ditarik kesimpulan bahwa didalam memotivasi Pegawai, kita harus mengetahui tentang apa yang dibutuhkan oleh para Pegawai tersebut secara langsung maupun tidak langsung didalam pelaksanaan pekerjaannya dalam usaha pencapaian tujuan bersama. 
6. Ciri-ciri Karyawan yang memiliki Motivasi Kerja tinggi dan rendah

Beberapa karakteristik dari motivasi kerja yang tinggi dan rendah menurut L.N Jewel (dalam Marliani, 2015 ), sebagai berikut :

(a) Ciri-ciri motivasi kerja pegawai yang tinggi:

1. Bersaing dalam berprestasi

2. Ingin segera mengetahui hasil konkret dari usaha

3. Tingkat aspirasinya menengah

4. Berorientasi pada masa akan datang

5. Bersaing dalam berprestasi

6. Tidak suka membuang-buang waktu, serta mempunyai rasa tanggung jawab

7. Percaya diri dan ulet dalam menjalankan tugas.

(b) Ciri-ciri motivasi kerja pegawai yang rendah :

1. Kemampuan bersaing dalam berprestasi rendah

2. Cenderung tidak peduli dengan hasil pekerjaan yang dilakukan, tingkat aspirasi rendah

3. Suka membuang-buang waktu, serta tidak bertanggung jawab

4. Tidak percaya diri dan tidak ulet dalam bekerja.

Berdasarkan uraian diatas bahwa ciri-ciri pegawai yang memiliki motivasi kerja yang tinggi Pegawai yang mendapat penghargaan, tidak suka membuang-buang waktu serta mempunyai rasa tanggung jawab dan berani mengambil dan memikul resiko. Sebaliknya, Pegawai yang motivasi kerja 
yang rendah seperti Kemampuan bersaing dalam berprestasi rendah, Cenderung tidak peduli dengan hasil pekerjaan yang dilakukan, tingkat aspirasi rendah, suka membuang-buang waktu, tidak bertanggung jawab, tidak percaya diri dan tidak ulet dalam bekerja.

\section{E. Hubungan Antar Variabel}

a) Hubungan Kepuasan Kerja dengan Kinerja

Kepuasan kerja adalah tingkat perasaan menyenangkan yang diperoleh dari penilaian pekerjaan seseorang atau pengalaman kerja (Colquitt, LePine, Wesson, 2011). Adapun faktor-faktor yang mempengaruhi kepuasan kerja menurut Robbins (dalam Ali, 2011) adalah kerja yang secara mental mendukung, ganjaran yang pantas, kondisi kerja yang mendukung, rekan kerja yang mendukung dan kesesuaian kepribadian dan pekerjaan. Menurut Luthans (dalam Alamsyah, 2006), bahwa salah satu ciri-ciri pegawai yang memiliki kepuasan kerja yang tinggi adalah memiliki pencapaian prestasi kerja, kesehatan fisik yang lebih baik, lebih produktif, memelajari tugas yang berhubungan dengan pekerjaan baru dengan lebih cepat, memiliki sedikit kecelakaan kerja, mengajukan sedikit keluhan, dan menurunkan tingkat stress. Dengan demikian, dapat dikatakan bahwa pegawai yang memperoleh kepuasan kerja yang tinggi, dalam bekerja yang biasanya dia menyelesaikan hanya 3 pekerjaan dalam sehari, menjadi 10 pekerjaan terselesaikan dalam sehari karena, dia memiliki kemampuan dalam berprestasi yang sungguh- 
sungguh dalam bekerja. Sehingga hal tersebut, tentu akan meningkatkan kinerja menjadi maksimal.

Bentuk hubungan kepuasan kerja dengan kinerja adalah sebagai berikut : kinerja merupakan nilai dari seperangkat perilaku Pegawai yang berkontribusi baik secara positif atau negative terhadap pemenuhan tujuan organisasinya. Ada beberapa faktor yang mempengaruhi kinerja, salah satunya adalah kepuasan kerja menurut Robbin (dalam Kasmir, 2016). Kepuasan kerja adalah cara Pegawai merasakan dirinya atau pekerjaannya Menurut Wexley dan Yukl (dalam Mangkunegara, 2013). Dengan kata lain, Pegawai memiliki kemampuan dalam menjalan pekerjaan dengan perasaan yang positif dan menyenangkan dalam pencapaian prestasi kerja yang maksimal dengan baik. Dengan demikian, jelas bahwa kepuasan kerja berpengaruh terhadap kinerja, seseorang yang memiliki kinerja yang tinggi, akan membuat pegawai terhindar dari perilaku-perilaku keorganisasian yang negative seperti : membolos, mangkir kerja, pindah kerja ketempat lain, mengeluh dan tidak peduli dengan hasil pekerjaan yang dilakukan, meninggalkan jam kerja, karena kinerja adalah nilai dari seperangkat perilaku Pegawai yang berkontribusi, baik secara positif atau negative terhadap pemenuhan tujuan organisasi.

Dari uraian diatas, dapat disimpulkan bahwa terdapat hubungan positif dan signifikan antara kepuasan kerja dengan kinerja Pegawai Dinas Kesehatan Kabupaten Tapanuli Utara.Artinya, semakin tinggi Motivasi kerja, maka semakin baik pula kinerja yang dimiliki pegawai. Sebalinya, 
semakin rendah kepuasan kerja pada, maka semakin buruk pula kinerja yang dimiliki Pegawai.

b) Hubungan Motivasi Kerja dengan Kinerja

Hubungan antara Motivasi kerja dengan kinerja adalah motivasi kerja rendah, maka kinerjanya akan rendah pula meskipun kemampuan ada dan baik, serta peluangnya tersedia. Karena kedudukan dan hubungan itu, maka sangatlah strategis jika pengembangan kinerja individual dimulai dari peningkatan motivasi kerja (Ulfah, 2008). Motivasi kerja sebagai faktor pendorong faktor yang mengarahkan dan mendorong perilaku atau keinginan seseorang untuk melakukan suatu kegiatan yang dinyatakan dalam bentuk usaha yang keras menurut Merihot (2003).

Adapun faktor-faktor yang dapat mempengaruhi motivasi kerja menurut Stoner dan Winkel (dalam Ali, 2011) adalah karateristik individu, karakteristik pekerjaan dan karakteristik situasi kerja. Menurut L.N Jewel (dalam Marliani, 2015), mengatakan bahwa ciri-ciri pegawai yang memiliki motivasi kerja yang tinggi adalah bersaing dalam berprestasi, ingin segera mengetahui hasil konkret dari usaha, tingkat aspirasinya menengah, berorientasi pada masa akan datang, dan tidak suka membuang-buang waktu serta, mempunyai rasa tanggung jawab, serta percaya diri dan ulet dalam menjalankan tugas. Dengan demikian, dapat dikatakan bahwa Pegawai yang motivasi kerjanya tinggi, dalam bekerja dia tidak mau membuang-buang waktu, sehingga dalam bekerja dia bisa 
menyelesaikan pekerjaannya yang lebih maksimal lagi dengan bersaing dalam berprestasi karena dia sungguh-sungguh dalam menyelesaikan.

Bentuk hubungan motivasi kerja dengan kinerja adalah sebagai berikut kinerja merupakan fungsi dari komponen sumber daya manusia yang meliputi seleksi, motivasi, latihan dan pengembangan Menurut Aziz (dalam Sihar, 2015). Sedangkan menurut Robbin (dalam Sihar, 2015), Bahwa kinerja adalah hasil dari interaksi antara motivasi kerja, kemampuan dan peluang. Ada beberapa faktor yang mempengaruhi kinerja salah satunya adalah motivasi kerja menurut Robbin (dalam Kasmir, 2016). Motivasi kerja dalam penelitian ini mengacu pendapat Merihot (2003), yaitu faktor-faktor yang mengarahkan dan mendorong perilaku atau keinginan seseorang untuk melakukan suatu kegiatan yang dinyatakan dalam bentuk usaha yang keras dan mempertimbangkan arah, intensitas dan ketekunannya dalam usaha mencapai tujuan. Unsur intensitas menyangkut seberapa keras seseorang berusaha berusaha, unsur ini merupakan yang paling difokuskan bila membicarakan tentang motivasi kerja.

Motivasi kerja dapat mempengaruhi pencapaian prestasi kerja pegawai dalam menyelesaikan setiap pekerjaan.Artinya semakin tinggi Motivasi kerja pada diri Pegawai, maka semakin baik pula kinerja pegawai. Hal ini sejalan dengan pendapat Kasumaswari (2007), bahwa motivasi kerja untuk memperbaiki kinerja berhubungan dengan perasaan pemenuhan diri, pencapaian dan pengakuan. Dengan adanya Motivasi 
kerja positif pada diri pegawai, membuat pegawai sadar akan memperbaiki kinerja berdasarkan kemauannya sendiri tanpa adanya paksaan dari orang lain dan lebih semangat dalam menjalankan dan melaksanakan setiap tugas yang diberikan. Sebaliknya semakin rendah Motivasi kerja yang dimiliki pegawai, maka semakin rendah pula kinerja yang dimiliki pegawai. Individu yang termotivasi dalam memiliki kinerja yang baik tetap bertahan pada pekerjaan cukup lama untuk mencapai tujuan mereka Menurut Kasumaswari (2007).

Dari uraian diatas, dapat disimpulkan bahwa terdapat hubungan positif dan signifikan antara motivasi kerja dengan kinerja Pegawai Dinas Kesehatan Kabupaten Tapanuli Utara. Artinya, semakin tinggi motivasi kerja, maka semakin baik pula kinerja yang dimiliki pegawai. Sebalinya, semakin rendah motivasi kerja pada, maka semakin buruk pula kinerja yang dimiliki pegawai. Singkatnya, motivasi kerja memberikan pengaruh terhadap kinerja.

c) Hubungan Kepuasan Kerja dan Motivasi Kerja dengan Kinerja

Menurut Colquitt, 2011), bahwa kinerja adalah nilai dari seperangkat perilaku kerja pegawai yang berkontribusi baik secara positif atau negative terhadap pemenuhan tujuan organisasi. Ada beberapa faktor yang mempengaruhi kinerja, salah satunya adalah kepuasan kerja dan Motivasi kerja menurut Robbin (dalam Kasmir, 2016). Bentuk hubungan kepuasan kerja dengan kinerja adalah sebagai berikut : Kinerja merupakan 
nilai dari seperangkat perilaku pegawai yang berkontribusi baik secara positif atau negative terhadap pemenuhan tujuan organisasi nya. Kepuasan kerja adalah cara Pegawai merasakan dirinya atau pekerjaannya Menurut Wexley dan Yukl (dalam Mangkunegara, 2013). Dengan kata lain, pegawai memiliki kemampuan dalam menjalan pekerjaan dengan perasaan yang positif dan menyenangkan dalam pencapaian prestasi kerja yang maksimal dengan baik. Dengan demikian, jelas bahwa kepuasan kerja berpengaruh terhadap Kinerja, seseorang yang memiliki kinerja yang tinggi, akan membuat pegawai terhindar dari perilaku - perilaku kerorganisasian yang negative seperti : membolos, mangkir kerja, pindah kerja ketempat lain, mengeluh dan tidak peduli dengan hasil pekerjaan yang dilakukan, meninggalkan jam kerja, karena kinerja adalah nilai dari seperangkat perilaku Pegawai yang berkontribusi, baik secara positif atau negative terhadap pemenuhan tujuan organisasi. Pegawai yang merasakan ketidakpuasan dalam bekerja, seharusnya menjadi sinyal bagi pihak Instansi untuk waspada.Hal ini disebabkan bahwa kepuasan kerja berpengaruh kepada kinerja Pegawai dan pada akhirnya berhubungan dengan produktivitas kerja Pegawai (Sutrisni, 2009).

Bentuk hubungan motivasi kerja dengan kinerja adalah sebagai berikut kinerja merupakan fungsi dari komponen sumber daya manusia yang meliputi seleksi, motivasi, latihan dan pengembangan menurut Aziz (dalam Sihar, 2015). Sedangkan menurut Robbin (dalam Sihar, 2015), Bahwa kinerja adalah hasil dari interaksi antara motivasi kerja, 
kemampuan dan peluang. Motivasi kerja dalam penelitian ini mengacu pendapat Merihot (2003), yaitu faktor-faktor yang mengarahkan dan mendorong perilaku atau keinginan seseorang untuk melakukan suatu kegiatan yang dinyatakan dalam bentuk usaha yang keras dan mempertimbangkan arah, intensitas dan ketekunannya dalam usaha mencapai tujuan. Unsur intensitas menyangkut seberapa keras seseorang berusaha berusaha, unsur ini merupakan yang paling difokuskan bila membicarakan tentang motivasi kerja.

Menurut L.N Jewel (dalam Marliani, 2015), mengatakan bahwa ciri-ciri pegawai yang memiliki motivasi kerja yang tinggi adalah bersaing dalam berprestasi, ingin segera mengetahui hasil konkret dari usaha, tingkat aspirasinya menengah, berorientasi pada masa akan datang, dan tidak suka membuang-buang waktu serta, mempunyai rasa tanggung jawab, serta percaya diri dan ulet dalam menjalankan tugas. Dengan demikian, dapat dikatakan bahwa pegawai yang motivasi kerjanya tinggi, dalam bekerja dia tidak mau membuang-buang waktu, sehingga dalam bekerja dia bisa menyelesaikan pekerjaannya yang lebih maksimal lagi dengan bersaing dalam berprestasi karena dia sungguh-sungguh dalam menyelesaikan.

Penelitian ini menekankan pada faktor dalam diri Pegawai itu sendiri, yakni motivasi kerja, dimana motivasi kerja menurut Herzberg (dalam Ali, 2011) dipengaruhi oleh dua aspek, yakni aspek intrinsik dari dalam diri dan aspek ektrinsik dari luar Pegawai. Kedua aspek ini, sangat 
penting dalam memunculkan motivasi kerja. Aspek ekstrinsik terdiri terdiri dari prestasi, pengakuan, tanggung jawab, kemajuan, perkembangan, pekerjaan itu sendiri. Aspek Ekstrinsik terdiri dari gaji, pengawasan, kebijakan dan administrasi, kondisi kerja, hubungan antar pribadi, keamanan kerja. Aspek intrinsik, merupakan salah satu faktor yang terpenting dalam meninjau motivasi kerja seseorang. Artinya, jika dari dalam diri seseorang tidak muncul dorongan untuk bekerja, maka kondisi ini akan menurunkan motivasi kerja Pegawai.

Beberapa pendapat menunjukan bahwa secara umum motivasi kerja mempengaruhi kepuasan kerja pegawai. Seperti yang dikemukakan Robbins (dalam Ali, 2011), bahwa faktor-faktor yang mempengaruhi kerja yang secara mental mendukung, ganjaran yang pantas, kondisi kerja yang mendukung, rekan kerja yang mendukung, dan kesesuaian kepribadian, dan pekerjaan. Selain itu Rivai'I (dalam Ali, 2011), menjelaskan bawha kepuasan kerja dipengaruhi oleh dua faktor, antara lain faktor instrinsik (merupakan faktor yang berasal dari dalam diri pegawai dan dibawa oleh setiap pegawai sejak mulai bekerja ditempat kerjanya) dan faktor ektrinsik ( merupakan hal-hal yang berasal dari luar diri pegawai yang antara lain tediri dari kondisi fisik lingkungan kerja, interaksinya dengan pegawai yang lainnya, dan sistem penggajian).

Menurut teori penguatan yang dikemukakan Steers dan Porter (dalam Ali, 2011) bahwa perilaku seseorang merupakan fungsi dari konsekuensi perilaku tersebut. Dengan kata lain, penguatan yang 
dilakukan oleh atasan menentukan perilaku bawahannya, karena itu yang perlu diamati adalah konsekuensi yang segera timbul terhadap respons tertentu dan apakah konsekuensi itu berakibat pada kecenderungan diulanginya perilaku tertentu itu atau tidak. Melihat pandangan yang dikemukakan ahli diatas, maka dalam hal ini apabila kepuasan kerja pegawai tinggi, maka hal ini ditentukan oleh kondisi motivasi kerja pegawai tersebut yang membuat kinerja maksimal.

Berdasarkan penjelasan diatas, maka dapat disimpulkan bahwa apabila seorang Pegawai memiliki motivasi kerja yang tinggi, maka Pegawai tersebut akan merasakan kepuasan dalam bekerja dan membuat kinerja yang baik atau maksimal. Demikian pula sebaliknya, jika seorang Pegawai tidak termotivasi dalam bekerja, maka Pegawai tersebut akan sulit untuk mendapatkan kepuasan dalam bekerja sehingga menimbulkan kinerja Pegawai tidak maksimal. 


\section{F. Kerangka Konseptual}

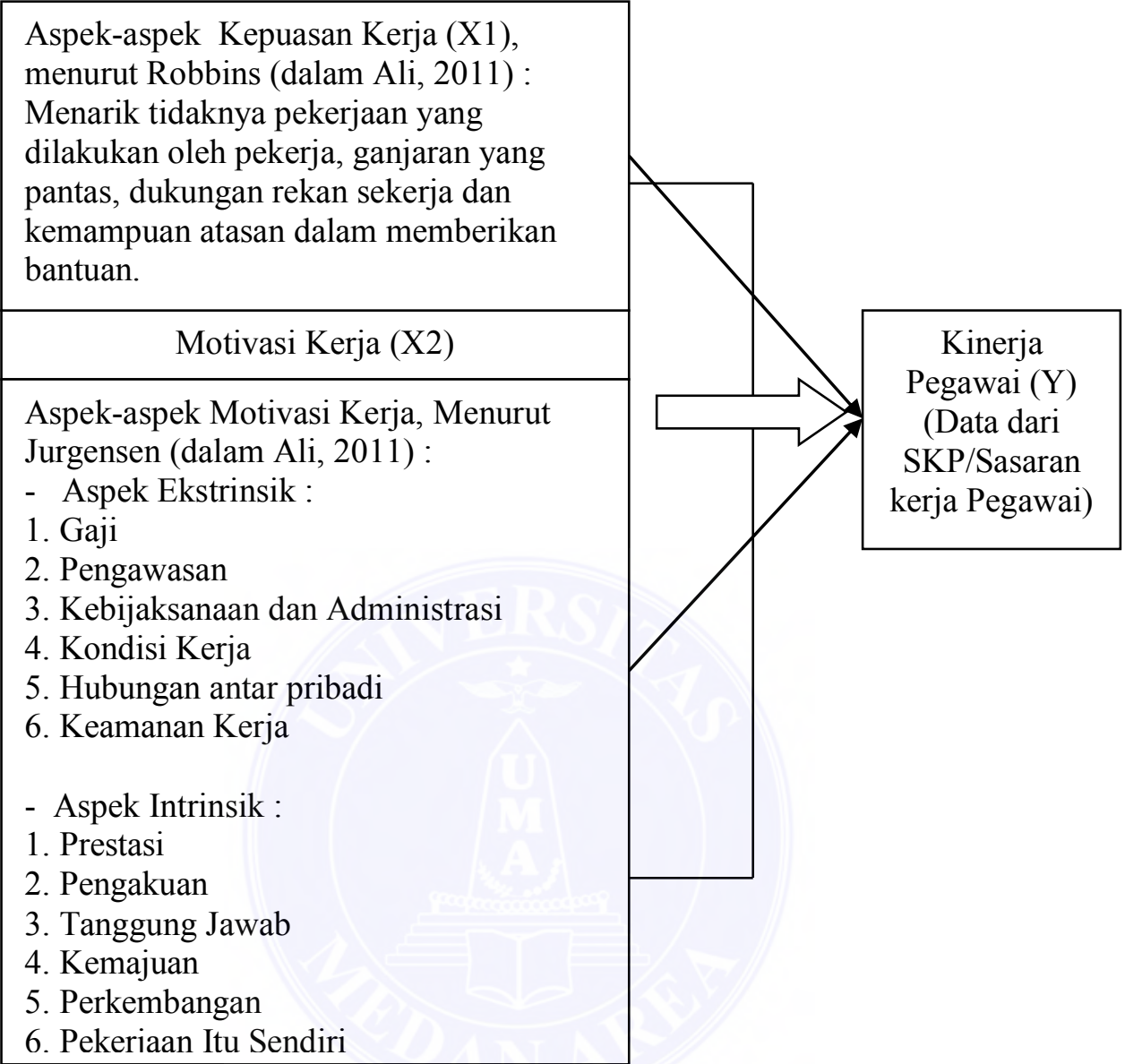

\section{G. Hipotesis}

Berdasarkan uraian teoritis yang telah dikemukakan diatas, hipotesis yang diajukan peneliti adalah :

1) "Ada hubungan positif antara kepuasan kerja dengan dengan kinerja", dengan asumsi semakin tinggi kepuasan kerja yang dimiliki oleh Pegawai, maka semakin tinggi kinerja nya. Sebaliknya semakin rendah kepuasan kerja maka semakin rendah kinerjanya 
2) "Ada hubungan positif antara motivasi kerja dengan kinerja", dengan asumsi bahwa semakin tinggi motivasi kerja yang dimiliki oleh Pegawai, maka semakin tinggi kinerja nya. Sebaliknya semakin rendah motivasi kerja maka semakin rendah kinerjanya

3) "Ada hubungan positif antara kepuasan kerja dan motivasi kerja dengan kinerja”, dengan asumsi semakin tinggi pengaruh dari kepuasan kerja dan motivasi kerja dengan kinerja pegawai, maka semakin tinggi kinerjanya. Sebaliknya semakin rendah kepuasan kerja dan motivasi kerja dengan kinerja maka semakin rendah kinerjanya. 


\section{BAB III}

\section{METODE PENELITIAN}

\section{A. Tipe Penelitian}

Sugiono (2012), mengatakan metode penelitian sangat menentukan suatu penelitian karena menyangkut cara yang benar dalam pengumpulan data, analisa data dan pengambilan keputusan hasil penelitian. Penelitian ini menggunakan tipe kuantitatif untuk mengetahui hubungan kepuasan kerja dan motivasi kerja dengan kinerja pada pegawai dan adanya upaya untuk menentukan variabel beserta alat ukurnya, serta merumuskan hipotesis dan secara logis menjelaskan hasil penelitian. Metode ini disebut metode kuantitatif karena data penelitian berupa angka-angka.

\section{B. Identifikasi Variabel Penelitian}

Identifikasi variabel yang terdapat dalam sebuah penelitian berfungsi untuk menentukan alat pengumpulan data dan teknik analisis data yang digunakan. Variabel masalah yang harus dipecahkan harus diidentifikasi, dipilih dan dirumuskan dengan tepat untuk menguji hipotesis penelitian. Variabel yang diukur dalam penelitian ini adalah :

a. Variabel Terikat (Y)

1. Kinerja 
b. Variabel Bebas $(\mathrm{X})$, terdiri dari

1. Kepuasan kerja (X1)

2. Motivasi kerja (X2)

\section{Definisi Operasional Variabel Penelitian}

Azwar (2015), mengatakan suatu definisi operasional merupakan spesifikasi kegiatan peneliti dalam mengukur suatu variabel. Suatu defenisi operasional merupakan semacam buku pegangan yang berisi petunjuk bagi peneliti. Definisi ini memberikan batasan atau arti suatu variabel tersebut.

Adapun definisi operasional variabel dalam penelitian ini adalah:

a. Kinerja Pegawai (Y)

Kinerja pegawai adalah hasil kerja yang dicapai individu yang disesuaikan dengan peran atau tugasnya dalam periode tertentu, dihubungkan dengan suatu ukuran nilai atau standar tertentu dari instansi tempat individu bekerja.

Adapun untuk mengukur kinerja, dengan merata-ratakan nilai prestasi kerja pegawai dari tahun 2015 dan tahun 2016 pada SKP (Sasaran Kerja Pegawai) dari masing-masing Pegawai Negeri Sipil.

b. Kepuasan kerja (X1)

Kepuasan kerja adalah menyangkut sikap dan penilaian positif atau negatif seseorang atas hasil pekerjaannya dan merupakan selisih dari sesuatu yang seharusnya ada (harapan) dengan kenyataan. Data mengenai kepuasan kerja diungkap melalui skala kepuasan kerja yang disusun berdasarkan aspek-aspek kepuasan kerja, yaitu: menarik tidaknya 
pekerjaan, ganjaran yang pantas, dukungan rekan sekerja, dan kondisi kerja.

c. Motivasi kerja (X2)

Motivasi kerja merupakan segala sesuatu yang menimbulkan gairah, hasrat, keinginan dan energi dari dalam diri sesorang yang mempengaruhi dan mengarahkan serta memelihara perilakunya untuk mencapai tujuan yang diinginkan, sesuai dengan lingkup kerja. Motivasi kerja diukur dengan skala motivasi kerja, yang disusun sendiri oleh peneliti berdasarkan aspek-aspek motivasi kerja, yaitu : a. Aspek ekstrinsik, terdiri dari : gaji, penyelia, hubungan antar pribadi, kebijaksanaan dan administrasi, kondisi kerja, dan keamanan kerja. b. Aspek intrinsik, terdiri dari : prestasi, penghargaan, tanggung jawab, kemajuan, perkembangan, dan pekerjaan itu sendiri.

\section{Subjek Penelitian}

1. Populasi

Menurut Sugiono (2012), populasi adalah wilayah generalisasi yang terdiri atas subyek atau obyek yang mempunyai kualitas dan karakteristik tertentu yang ditetapkan oleh peneliti. Jadi populasi bukan hanya orang, tetapi juga obyek dan benda-benda alam yang lain. Populasi bukan sekedar jumlah yang ada pada obyek/subyek yang dipelajari, tetapi meliputi seluruh karakteristik/sifat yang dimiliki oleh subyek atau obyek itu. 
Populasi dalam penelitian ini adalah Pegawai Negeri Sipil Dinas Kesehatan Kabupaten Tapanuli Utara yang berjumlah 86 orang Pegawai Negeri Sipil.

2. Sampel dan teknik sampling

Menurut Sugiono (2012), sampel adalah bagian dari jumlah dan karakteristik yang dimiliki oleh populasi tersebut. Untuk itu sampel yang diambil dari populasi harus betul-betul representatif (mewakili). Teknik pengambilan sampel pada penelitian ini adalah teknik total sampling atau sampling jenuh. Sampling jenuh adalah teknik penentuan sampel bila semua anggota populasi digunakan sebagai sampel. Penelitian ini akan dilakukan pada Pegawai Negeri Sipil Dinas Kesehatan Kabupaten Tapanuli Utara dengan jumlah 86 orang Pegawai Negeri Sipil.

\section{E. Metode Pengumpulan Data}

Metode pengumpulan data yang digunakan dalam penelitian iniadalah metode dokumentasi dan metode skala.

1) Metode Dokumen

Metode dokumen diambil dari dokumentasi Instansi, digunakan untuk melihat dan mengumpulkan data tentang kinerja Pegawai, yaitu berupa Sasaran Kerja Pegawai (SKP).

Data kinerja pegawai diperoleh dengan menggunakan Sasaran Kerja Pegawai. Sasaran kerja Pegawai ini, digunakan untuk mengetahui sejauh mana tingkat kinerja Pegawai. Artinya, semakin tinggi skor Sasaran 
Kerja Pegawai, maka semakin menunjukkan tingginya kinerja Pegawai, sebaliknya semakin rendah skor Sasaran Kinerja Pegawai maka semakin menunjukkan rendahnya tingkat kinerja Pegawai.

Tata cara Penilaian Sasaran Kerja Pegawai (SKP)

Nilai capaian SKPdinyatakan dengan angka dan sebutan, sebagai berikut :
a. 91 - ke atas
: Sangat baik
b. $76-90$
: Baik
c. $61-75$
: Cukup
d. $51-60$
: Kurang
e. 50 - Ke bawah
: Buruk

\begin{tabular}{|l|l|}
\hline Kriteria Nilai & \multicolumn{1}{|c|}{ Keterangan } \\
\hline $91-100$ & $\begin{array}{l}\text { Hasil kerja sempurna, tidak ada kesalahan, tidak ada } \\
\text { revisi, dan pelayanan diatas standar yang ditentukan dan } \\
\text { lain - lain }\end{array}$ \\
\hline $76-90$ & $\begin{array}{l}\text { Hasil kerja mempunyai 1 (satu) atau 2 (dua) kesalahan } \\
\text { kecil, tidak ada kesalahan besar, revisi, dan pelayanan } \\
\text { sesuai standar yang telah ditentukan dan lain - lain }\end{array}$ \\
\hline $61-75$ & $\begin{array}{l}\text { Hasil kerja mempunyai 3 (tiga) atau 4 (empat) kesalahan } \\
\text { kecil, dan tidak ada kesalahan besar, revisi, dan } \\
\text { pelayanan cukup memenuhi standar yang ditentukan dan } \\
\text { lain - lain }\end{array}$ \\
\hline $51-60$ & $\begin{array}{l}\text { Hasil kerja mempunyai 5 (lima) kesalahan kecil dan ada } \\
\text { kesalahan besar, revisi, dan pelayanan tidak cukup } \\
\text { memenuhi standar yang ditentukan dan lain - lain }\end{array}$ \\
\hline 50 ke bawah & $\begin{array}{l}\text { Hasil kerja mempunyai lebih dari 5 (lima) kesalahan } \\
\text { kecil dan ada kesalahan besar, kurang memuaskan, } \\
\text { revisi, pelayanan dibawah standar yang ditentukan dan } \\
\text { lain - lain }\end{array}$ \\
\hline
\end{tabular}

Penilaian kegiatan tugas jabatan yang terdiri dari aspek kuantitas, aspek kualutas, aspek waktu, serta aspek biaya dengan rumus-rumusnya tertera dilampiran 
2) Metode Skala

Metode skala adalah suatu metode penelitian dengan menggunakan daftar pertanyaan yang berisi aspek-aspek yang hendak diukur, yang harus dijawab atau dikerjakan oleh sampel penelitian dan berdasarkan atas jawaban sampel, peneliti mengambil kesimpulan mengenai sampel yang diteliti (Suryabrata, 1990). Dalam penelitian ini metode skala digunakan untuk variabel bebas dan variabel tergantung.

Dipilihnya metode skala ini berdasarkan atas anggapan:

1. Bahwa sampel adalah orang yang paling tahu tentang dirinya sendiri

2. Bahwa apa yang dinyatakan oleh sampel kepada peneliti adalah benar dan dapat dipercaya.

3. Bahwa interpretasi sampel tentang pertanyaan-pertanyaan yang diajukan kepadanya adalah sama dengan apa yang dimaksudkan oleh peneliti. (Hadi, 1993).

Skala yang digunakan dalam penelitian ini menggunakan skala model Likert yang dimodifikasi. Modifikasi yang dilakukan adalah dengan tidak mengikutsertakan pilihan jawaban $\mathrm{N}$ (Netral) dengan alasan untuk menghindari kecenderungan sampel memilih pada satu jawaban alternatif $\mathrm{N}$ (netral) yang berarti tidak dapat menentukan pilihan jawaban. Menurut Hadi (1993), Skala Likert merupakan skala yang paling banyak digunakan, karena skala ini dapat dinilai setuju atau tidak setuju. Dimana, penilaian antara setuju dengan tidak setuju dapat dibagi menjadi empat kategori. Sedangkan bentuk 
pernyataannya dapat dikelompokkan menjadi 2 (dua), yaitu pernyataan yang favorable dan pernyataan yang unfavorable.

Sistem penilaian keempat kategori tersebut, memiliki empat alternatif jawaban yang favourable, yaitu: sangat setuju (SS) nilai 4, setuju (S) nilai 3, tidak setuju (TS) nilai 2, sangat tidak setuju (STS) nilai 1. Kemudian untuk pernyataan unfavourable, yaitu: sangat setuju (SS) nilai 1, setuju (S) nilai 2, tidak setuju (TS) nilai 3, sangat tidak setuju (STS) nilai 4. Untuk lebih jelasnya dapat dilihat pada tabel dibawah ini :

Tabel 3.1

Skor Alternatif Jawaban Pernyataan Favourable dan Unfavourable

\begin{tabular}{|c|c|c|c|}
\hline $\begin{array}{c}\text { Alternatif } \\
\text { Jawaban }\end{array}$ & $\begin{array}{c}\text { Skor } \\
\text { Favourable }\end{array}$ & $\begin{array}{c}\text { Alternatif } \\
\text { Jawaban }\end{array}$ & $\begin{array}{c}\text { Skor } \\
\text { Unfavourable }\end{array}$ \\
\hline Sangat Setuju (SS) & 4 & Sangat Setuju (SS) & 1 \\
\hline Setuju (S) & 3 & Setuju (S) & 2 \\
\hline Tidak Setuju (TS) & 2 & Tidak Setuju (TS) & 3 \\
\hline $\begin{array}{c}\text { Sangat Tidak Setuju } \\
\text { (STS) }\end{array}$ & 1 & $\begin{array}{c}\text { Sangat Tidak Setuju } \\
\text { (TS) }\end{array}$ & 4 \\
\hline
\end{tabular}

Ada dua skala yang digunakan dalam penelitian ini, yaitu Skala Kepuasan Kerja dan Skala Motivasi Kerja.

a) Skala kepuasan kerja

Angket ini berisi aitem yang bertujuan untuk mengukur kepuasan kerja pegawai. Angket terdiri dari aitem yang merupakan penjabaran dari aspek-aspek kepuasan kerja, yaitu: Menarik tidaknya pekerjaan, ganjaran yang pantas, dukungan rekan sekerja, dan kondisi kerja.

Respon jawaban dalam angket penelitian menggunakan empat pilihan, yaitu Sangat Setuju (SS), Setuju (S), Tidak Setuju (TS), dan 
Sangat Tidak Setuju (STS). Untuk aitem yang favorabel, pilihan SS akan mendapatkan skor empat, pilihan S akan mendapatkan skor tiga, pilihan TS akan mendapatkan skor dua, dan pilihan STS akan mendapatkan skor satu. Sedangkan untuk aitem yang unfavorable pilihan SS akan mendapatkan skor satu, pilihan S mendapatkan skor dua, pilihan TS akan mendapatkan skor tiga, dan pilihan STS akan mendapatkan skor empat. Skala tersebut terdiri 30 aitem.

b). Skala Motivasi Kerja

Untuk mengungkap motivasi kerja karyawan, digunakan 2 aspek yang mendorong timbulnya dan sekaligus mempengaruhi motivasi kerja yaitu:

a. Aspek ekstrinsik, terdiri gaji, penyelia, hubungan antar pribadi, kebijaksanaan dan administrasi, kondisi kerja, dan keamanan kerja.

b. Aspek intrinsik, terdiri prestasi, pengakuan, tanggung jawab, kemajuan, perkembangan, dan pekerjaan itu sendiri.

Respon jawaban dalam angket penelitian menggunakan empat pilihan, yaitu Sangat Setuju (SS), Setuju (S), Tidak Setuju (TS), dan Sangat Tidak Setuju (STS). Untuk aitem yang favorabel, pilihan SS akan mendapatkan skor empat, pilihan $\mathrm{S}$ akan mendapatkan skor tiga, pilihan TS akan mendapatkan skor dua, dan pilihan STS akan mendapatkan skor satu. Sedangkan untuk aitem yang unfavorabelpilihan SS akan mendapatkan skor satu, pilihan S mendapatkan skor dua, pilihan TS akan 
mendapatkan skor tiga, dan pilihan STS akan mendapatkan skor empat. Skala tersebut terdiri 70 aitem.

\section{F. Validitas Dan Reliabilitas Alat ukur}

Sampai pada pengolahan data, data yang akan diolah berasal dari alat ukur yang mencerminkan fenomena apa yang diukur. Untuk itu perlu dilakukan analisis butir, validitas dan realibilitas.

\section{Validitas Alat Ukur}

Menurut Hadi (1990) suatu alat ukur dikatakan valid apabila dapat mengukur apa yang sebenarnya harus diukur. Alat ukur dikatakan teliti apabila alat itu mempunyai kemampuan yang cermat menunjukkan ukuran besar kecilnya gejala yang diukur.

Validitas menunjukkan kepada ketepatan dan kecermatan tes dalam menjalankan fungsi pengukurannya. Suatu tes dikatakan mempunyai validitas yang tinggi apabila tes tersebut memberikan hasil ukur yang sesuai dengan tujuan diadakannya tes tersebut.

Dalam penelitian ini skala diuji validitasnya dengan menggunakan teknik analisis product moment rumus angka kasar dari Pearson, yaitu mencari koefisien korelasi antara tiap butir dengan skor total (Hadi, 2007), dimana rumusnya adalah sebagai berikut: 


$$
r_{x y}=\frac{\sum X Y-\frac{\left(\sum X\right)\left(\sum Y\right)}{N}}{\sqrt{\left[\left(\sum X^{2}\right)-\frac{\left(\sum X\right)^{2}}{N}\right]\left[\left(\sum Y^{2}\right)-\frac{\left(\sum Y\right)}{N}\right]}}
$$

Keterangan:

$\mathrm{r}_{\mathrm{xy}} \quad$ : Koefisien korelasi anatara variabel $\mathrm{x}$ (skor subjek tiap item) dengan variabel y (total skor subjek dari keseluruhan item)

$\mathrm{XY}$ : Jumlah dari hasil perkalian antara setiap $\mathrm{X}$ dengan setiap $\mathrm{Y}$

$\mathrm{X}$ : Jumlah skor seluruh subjek tiap item

$\mathrm{Y} \quad$ : Jumlah skor keseluruhan item pada subjek

$\mathrm{X}^{2}$ : Jumlah kuadrat skor $\mathrm{X}$

$\mathrm{Y}^{2} \quad$ : Jumlah kuadarat skor $\mathrm{Y}$

$\mathrm{N} \quad$ : Jumlah subjek

2. Reliabilitas Alat Ukur

Konsep reliabilitas alat ukur adalah untuk mencari dan mengetahui sejauh mana hasil pengukuran dapat dipercaya. Reliabel dapat juga dikatakan kepercayaan, keajegan, kestabilan, konsistensi, dan sebagainya. Hasil pengukuran dapat dipercaya apabila dalam beberapa kali pelaksanaan pengukuran terhadap kelompok subjek yang sama diperoleh hasil yang relatif sama selama aspek dalam diri subjek yang diukur memang belum berubah. Analisis reliabilitas kedua alat ukur digunakan metode Cronbach's Alpha, metode ini sangat populer dan commonly digunakan pada skala uji yang berbentuk Likert. Uji ini dengan menghitung koefisien alpha. Data dikatakan reliabel apabila "r alpha" positif atau $r$ alpha $>r$ tabel. Nilai uji akan 
dibuktikan dengan menggunakan uji dua sisi pada taraf signifikansi 0,05, program SPSS secara default menggunakan nilai ini (Wibowo, 2012).

Sekarang (dalam Wibowo, 2012) menyatakan untuk melihat suatu data dikatakan reliabel dapat dilihat dengan menggunakan nilai batasan penentu, misalnya 0,6. Nilai yang kurang dari 0,6 dianggap dianggap memiliki reliabilitas yang kurang baik, sedangkan nilai 0,7 dianggap dapat diterima atau cukup baik, dan nilai diatas 0,8 dianggap baik.

Untuk mencari besaran angka reliabilitas dengan menggunakan metode Cronbach's Alpha dapat digunakan suatu rumus berikut ( Wibowo, 2012).

$$
\mathrm{r}_{11}=\left[\frac{k}{k-1}\right]\left[1-\frac{\sum \sigma_{b}^{2}}{\sigma_{1}^{2}}\right]
$$

$\mathrm{r}_{11}=$ reliabilitas instrumen

$\mathrm{k}=$ jumlah butir pernyataan

$\Sigma \sigma_{\mathrm{b}}^{2}=$ jumlah varian pada butir

$\sigma_{1}{ }^{2} \quad=$ varian total

\section{G. Metode Analisis Data}

Analisis data digunakan untuk melihat hubungan antara employee engagement dan produktivitas kerja. Sebelum diajukan analisis data, terlebih dahulu dilakukan uji persyaratan analisis terhadap variabel-variabel penelitian yang meliputi:

a. Uji Normalitas

Adapun maksud dari uji normalitas ini adalah untuk mengetahui apakah distribusi dari penelitian masing-masing variabel yaitu variabel bebas dan 
variabel tergantung telah menyebar secara normal. Uji normalitas dianalisis dengan menggunakan SPSS 21.0 for windows dan menggunakan teknik Kolmogorov-Smirnov Goodness Z,. Rumus sebagai berikut:

$$
x^{2}=\sum_{i=}^{k} \frac{(O i-E i)^{2}}{E i}
$$

Keterangan :

Oi $=$ Frekuensi hasil pengamatan pada klasifikasi ke-i

$\mathrm{Ei} \quad=$ Frekuensi yang diharapkan pada klasifikasi ke-i

b. Uji Linearitas

Adapun maksud dari uji linearitas ini adalah untuk mengetahui apakah antar variabel bebas dengan variabel terikat mempunyai hubungan linear atau tidak. Uji linearitas menggunakan SPSS 21.0 for windows.

Teknik analisis data yang digunakan dalam penelitian ini adalah teknik korelasi product moment dari Karl Person. Alasan menggunakan teknik ini karena penelitian ini memiliki tujuan ingin melihat hubungan antara satu variabel bebas dengan variabel terikat. Analisis data akan menggunakan alat bantu SPSS 21.0 for windows.

Menurut Arikunto (dalam Tarigan, 2009), formula dari teknik product moment yang dimaksud adalah sebagai berikut:

$$
r x y=\Sigma X Y-\Sigma \mathrm{X} \Sigma \mathrm{YN} \Sigma X^{2}-\Sigma X^{2} \mathrm{~N} \Sigma Y^{2}-\Sigma \mathrm{YN}
$$

Keterangan :

$r x y=$ Koefisien korelasi antara variable bebas $\mathrm{X}$ dengan variabel tergantung $\mathrm{Y}$

$\Sigma X Y=$ Jumlah hasil perkalian antara variabel $\mathrm{X}$ dan $\mathrm{Y}$

$\Sigma \mathrm{X}=$ Jumlah skor variabel bebas $\mathrm{X}$

$\Sigma \mathrm{Y} \quad=$ Jumlah skor variabel tergantung $\mathrm{Y}$

$\Sigma X^{2} \quad=$ Jumlah kuadrat skor $\mathrm{X}$ 


$$
\begin{array}{ll}
\Sigma Y^{2} & =\text { Jumlah kuadrat skor } \mathrm{Y} \\
\mathrm{N} & =\text { Jumlah subjek }
\end{array}
$$

\section{c. Uji Hipotesis}

Uji hipotesis adalah metode pengambilan keputusan yang didasarkan dari analisis data, baik dari percobaan yang terkontrol, maupun dari observasi (tidak terkontrol). Dalam statistik sebuah hasil bisa dikatakan signifikansi secara statistik jika kejadian tersebut hampir tidak mungkin disebabkan oleh faktor yang kebetulan, sesuai dengan batas probabilitas yang sudah ditentukan sebelumnya. Uji hipotesis menggunakan program SPSS 21.0 for windowsdengan menggunakan Penggunaan analisis Regresi Berganda, yang akan menunjukkan variabel yang dominan dalam mempengaruhi variabel terikat dan mengetahui sumbangan efektif dari masing-masing variabel.

Rumus Regresi Berganda adalah sebagai berikut :

$$
\mathrm{Y}=\mathrm{b} 0+\mathrm{b}_{1} \mathrm{X}_{1}+\mathrm{b}_{2} \mathrm{X}_{2}
$$

Dimana :

Y : Kinerja

$\mathrm{X} 1$ : Kepuasan kerja

$\mathrm{X} 2$ : Motivasi kerja

bo : besarnya nilai $\mathrm{Y}$ jika $\mathrm{X} 1$ dan $\mathrm{X} 2=0$

b1 : besarnya pengaruh $\mathrm{X} 1$ terhadap $\mathrm{Y}$ dengan asumsi $\mathrm{X} 2$ tetap

b2 : besarnya pengaruh X2 terhadap Y dengan asumsi X1 tetap 


\section{DAFTAR PUSTAKA}

Alamsyah, I. 2015. Pengaruh Motivasi Dan BebanKerja Terhadap Kepuasan Kerja Karyawan Pada Dinas Perindustrian, Perdagangan, Koperasi Dan Usaha Kecil Menengah Daerah Istimewah Yogyakarta. Sripsi. Yogyakarta : Fakultas Ekonomi UniversitasNegeri Yogyakarta.

Ali, I. 2011. Hubungan Antara Motivasi Kerja Dengan Kepuasan Kerja Pada Karyawan PT. Perkebunan Nusantara 2 Pabrik Kelapa Sawit Kebun Pagar Merbau. Skripsi. Medan: Fakultas Psikologi Universitas Medan Area. (tidak dipublikasikan).

Alwi,S.2001. Manajemen Sumber Daya Manusia. Stategi Keunggulan Kompetitif edisi pertama. Penerbit BPEE-Yogjakarta

Ardiyati, F. 2013. Perbedaan Motivasi Kerja Pada Karyawan Yang Sudah Menikah Dan Yang Belum Menikah. Skripsi. Yogyakarta: Fakultas Psikologi Universitas Sanata Dharma

Arikunto, (2010). Prosedur Penelitian : Suatu Pendekatan Praktek. Jakarta: Rineka Cipta Revisi As'ad, M. 2001. Psikologi Industri. Seri Sumber Daya Manusia.Yogyakarta: Liberty

Azwar, S. (2015).Reliabilitas dan Validitas (Edisi 4). Yogyakarta: Pustaka Pelajar Cherington, J. D., (2000), Organizational Behavior: The Management of Individuals and Organizational performance (Second Edition), Massachusets, Allyn and Bacon.

Colquitt, Jason A. Jeffery A. Lepine. Michael J. Wesson, OrganizationBehavior. Singapore: McGraw-Hill. 2011.

Deewar Mahesa, 2010, Analisis pengaruhmotivasi kerja dan kepuasan kerja terhadap kinerja karyawan dengan lama kerja sebagai variabel moderating (studi pada PT. Coca Cola amatil Indonesia (Central java). eprints.undip.ac.id Diakses Tanggal 25 November 2012

Gibson, I.1996. Organisasi. Perilaku. Struktur. Proses. Edisi kedelapan. Binarupa Aksara

Handoko, T. Hani. 2000, Manajemen Personalia dan Sumber Daya Manusia, Edisi Kedua, BPFE, Yogyakarta.

Hasibuan, Malayu. S.P. 2000 Manajemen Sumber Daya Manusia. Jakarta: Bumi Aksara 
Ivancevich, John M. Human Resource Management $10^{\text {th }}$. Singapore: McGrawHill International, Inc. 2012.

Kusumaswari, 2007. Hubungan Antara Motivasi Kerja, Karateristik Individu dan Kinerja Tenaga keperawatan di RSIA Hermina Bekasi. Depok: FKMUI; 2007.

Kasmir, S.E. 2016. Manajamen Sumber Daya Manusia (Teori dan Praktik) Edisi Pertama. Jakarta: PT. Raja Grafindo Persada.

Kreitner, Robert, dan Kinicki, Angelo. 1995. Perilaku Organisasi (Organizational Behavior). Buku 1 edisi 5. Jakarta: Salemba Empat.

Luthans. Fred. S. 1995. Organizational Behavior. Seventh Edition. Singapore: Mc. Graw Hill

Luthans, Fred. (2006). Perilaku Organisasi, Edisi 10, Penerbit Andi Offset L.

Mathis. Human Resource Management, USA: Ceange Learning. 2014

Mangkunegara, A.A.Anwar Prabu. 2013. Manajamen Sumber Daya Manusia Perusahaan. Bandung: PT Remaja Rosda karya

Marliani, M.Si. 2015. Psikologi Industri Dan Organisasi. Bandung: PT. Pustaka Setia

Mathis Robert L. dan Jackson John H. 2006. Human Resource Management. Terj. Jakarta: Salemba Empat.

Merihot Tuan Efendi. 2003. Manajemen Sumber Daya Manusia. Jakarta: GramediaWidya sarana Indonesia

Munandar, Arif (2001). Psikologi Industri Dan Organisasi. Jakarta: UI Press. Poewadar minta, W.J.S, 1991, Kamus Umum Bahasa Indonesia, Bina Aksara, Jakarta.

Rivai Veithzal. 2004. Manajemen Sumber Daya Manusia Untuk Perusahaan dari teori kepraktik. Jakarta: Raja Grafindo Persada.

Robbins, S.P, and Timothy A.J. 2007. Organizational Behavior. New Jersey: PEARSON Prentice Hall

Robert L. Mathis John H. Jackson. 2001. Sumber Daya Manusia. Terj. Jimmy Sadeli. Jakarta: Empat 
Sihar, 2015. Hubungan antara motivasi kerja dengan kinerja karyawan PT. Kereta api Medan di UPT Balai Yasa Pulubrayan Medan. Skripsi. Medan: Fakultas Psikologi Universitas Medan Area. (tidak dipublikasikan).

Sugiono,(2012).Metode Penelitiaan Pendidikan Pendekatan Kuantitatif, Kualitatifdan R\&D. Alfabeta Bandung. Bandung

Steele:Johnson, D., Beauregard, R. S.,Hoover, P.D. and Schmidt, A. M. 2000. Goal Orientation and Task Demand Effects on Motivation, Affect, and Performance. Journal of Applied Psychology,85:724:738.

Wexley, K.N. and Yukl, G. 1997. Organizational Behavior and Personnel Psychology.Home wood. Illinois, Richard D. Irwin Inc.profits. 5th ed. New York: McGraw-Hill, Inc.

Yusmanita. 2013. Analisis Pengaruh Motivasi Kerja Dan Kepuasan Kerja Terhadap Kinerja Karyawan Pada PT. Lotte Shopping Indonesia Pekanbaru. Skripsi. Riau : Fakultas Ekonomi Dan Ilmu Sosial Universitas Islam Negeri Sultan Syarif Kasim Riau. (tidak dipublikasikan)

\section{Undang-undang :}

1. Undang No. 43 Tahun 1999

2. Undang-undang No. 5 Tahun 2014 Tentang Aparatur Sipil Negara

3. Undang-undangNomor 43 Tahun 1999 tentang Perubahan Atas Undangundang Nomor 8 Tahun 1974 tentang pokok-pokok kepegawaian.

4. Peraturan Perundang-undangan (PP 11 Tahun 2017) pada paragraf 6 pasal 142, tentang target kinerja dan uji kompetensi pejabat pimpinan tinggi

5. Peraturan Perundang-undangan (PP 11 Tahun 2017) BAB VI tentang penilaian kinerja pasal 228

6. Peraturan Perundang-undangan (PP 11 Tahun 2017) pada paragraf 7 pasal 144 tentang pemberhentian dari jabatan pimpinan tinggi 


\section{LAMPIRAN A}

Skala Kepuasan Kerja dan Skala Motivasi kerja 


\section{INSTRUMEN TEST MAHASISWA PSIKOLOGI UNIVERSITAS MEDAN AREA}

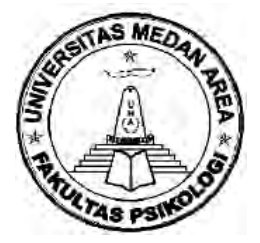

Sehubungan dengan penelitian yang sedang saya lakukan, maka saya memohon kesediaan Bapak/Ibu meluangkan waktu untuk mengisi skala ini. Penelitian ini bertujuan untuk keperluan ilmiah dan tidak akan merugikan saudara. Jawaban yang diberikan saya jamin kerahasiaannya. Atas kesediaan dan kerjasamanya saya ucapkan terima kasih.

\section{Data Diri}

Nama (inisial)

Usia

Jeniskelamin

\section{PETUNJUK PENGISIAN SKALA}

1. Skala ini terdiri dari dua bagian yaitu skala Kepuasan Kerja dan skala Motivasi Kerja. Bacalah masing-masing pernyataan dengan teliti dan jawablah dengan sejujur-jujurnya tanpa dipengaruhi oleh siapapun.

2. Skala ini bukan suatu tes, sehingga tidak ada jawaban yang BENAR atau SALAH.

3. Bacalah setiap pernyataan dengan seksama. Kemudian berikan jawaban anda pada setiap pernyataan dengan memberi tanda $(\sqrt{ })$ pada salah satu pilihan yang tersedia. Adapun pilihan jawaban yang tersedia yaitu :

SS : Apabila pernyataannya SANGAT SESUAI dengan diri anda

S : Apabila pernyataannya SESUAI dengan diri anda

TS : Apabila penyataannya TIDAK SESUAI dengan diri anda

STS: $\quad$ : Apabila penyataannya SANGAT TIDAK SESUAI dengan diri anda 


\section{Contoh Pengisian :}

No.

1. Saya bersemangat dalam bekerja
Alternatif Jawaban

\begin{tabular}{|c|c|c|c|}
\hline SS & S & TS & STS \\
$\sqrt{ }$ & & & \\
\hline
\end{tabular}

Jika anda ingin mengganti jawaban, maka coretlah pada jawaban yang salah $(\neq)$ dan berikan tanda $(\sqrt{ }$ ) pada jawaban yang anda anggap paling sesuai dengan diri anda.

\section{Contoh Penggantian Jawaban :}

No. Pernyataan

1. Saya bersemangat dalam bekerja
Alternatif Jawaban

\begin{tabular}{|c|c|c|c|}
\hline SS & S & TS & STS \\
$\neq$ & & $\sqrt{ }$ & \\
\hline
\end{tabular}

\section{SKALA I KEPUASAN KERJA}

No

\section{Pernyataan}

1. Saya senang menjalankan setiap tugas yang diberikan Instansi kepada saya

2. Saya menikmati pekerjaan setiap harinya karena disiplin ilmu saya

3. Saya senang saat sibuk bekerja

4. Saya rajin menjalankan tugas, ditempat saya bekerja sehari-hari

\begin{tabular}{|c|c|c|c|}
\hline SS & S & TS & STS \\
& & & \\
\hline
\end{tabular}

\begin{tabular}{|c|c|c|c|}
\hline SS & S & TS & STS \\
\hline
\end{tabular}

\begin{tabular}{|l|l|l|l|}
\hline SS & S & TS & STS \\
\hline
\end{tabular}

5. Saya senang bekerja di Instansi ini, karena diluar

\begin{tabular}{|l|l|l|l|}
\hline SS & S & TS & STS \\
\hline
\end{tabular}


dari gaji saya menerima gaji ke - 13

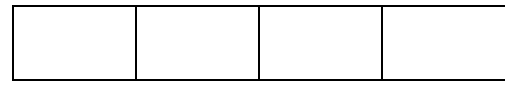

6. Saya hanya menjalankan tugas, jika adanya tunjangan struktural yang diberikan pada saya

\begin{tabular}{|c|c|c|c|}
\hline SS & S & TS & STS \\
\hline
\end{tabular}

7. Saya kecewa dengan menerima TTP (Tunjangan Tetap Pegawai) yang tidak sesuai dengan yang telah disepakati

\begin{tabular}{|c|c|c|c|}
\hline SS & S & TS & STS \\
& & & \\
\hline
\end{tabular}

8. Keadilan kebijakan promosi pegawai ditempat saya bekerja, sudah diterapkan dengan baik

\begin{tabular}{|c|c|c|c|}
\hline SS & S & TS & STS \\
& & & \\
\hline
\end{tabular}

9. Saya senang dengan adanya diberikan Tunjangan Hari Raya (THR) pada saya di tempat saya bekerja

\begin{tabular}{|c|c|c|c|}
\hline SS & S & TS & STS \\
& & & \\
& & & \\
\hline
\end{tabular}

10. Saya merasa puas bekerja di Instansi ini, karena setiap pegawai memiliki kesempatan untuk menduduki jabatan yang lebih tinggi

\begin{tabular}{|c|c|c|c|}
\hline SS & S & TS & STS \\
& & & \\
\hline
\end{tabular}

11. Promosi jabatan ditempat saya bekerja, dilakukan secara subjektif

\begin{tabular}{|c|c|c|c|}
\hline SS & S & TS & STS \\
& & & \\
\hline
\end{tabular}

12. Saya merasa lelah menyelesaikan pekerjaan yang yang diberikan pada saya sehari-hari

\begin{tabular}{|c|c|c|c|}
\hline SS & S & TS & STS \\
& & & \\
\hline
\end{tabular}


13. Pekerjaan yang dibeikan pada saya, tidak sesuai dengan kemampuan yang saya miliki

\begin{tabular}{|c|c|c|c|}
\hline SS & S & TS & STS \\
& & & \\
\hline
\end{tabular}

14. Saya bekerja dengan baik, agar mendapatkan promosi jabatan ditempat saya bekerja

\begin{tabular}{|c|c|c|c|}
\hline SS & S & TS & STS \\
& & & \\
\hline
\end{tabular}

15. Bagi saya, dengan dikirimnya saya oleh Instansi kepelatihan-pelatihan, merupakan kesempatan yang besar untuk saya promosi dalam jabatan

16. Saya merasa rekan kerja saya seperti keluarga saya

\begin{tabular}{|c|c|c|c|}
\hline SS & S & TS & STS \\
& & & \\
\hline
\end{tabular}

\begin{tabular}{|c|c|c|c|}
\hline SS & S & TS & STS \\
\end{tabular}

17. Apabila ada rekan kerja saya yang sakit, saya dan rekan kerja saya yang lainnya sepakat untuk menjenguk dan memotivasi rekan kerja kami yang sakit

\begin{tabular}{|c|c|c|c|}
\hline SS & S & TS & STS \\
& & & \\
\hline
\end{tabular}

18. Saya merasa terganggu bekerja diruangan yang bersamaan dengan rekan kerja saya, karena ruangan kerja yang kotor

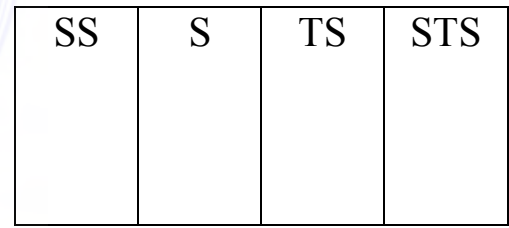

19. Apabila saya berhalangan hadir, rekan kerja saya akan memberikan informasi tentang pekerjaan saya yang tertinggal

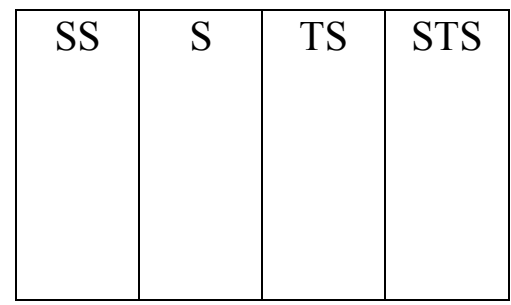

20. Saya kurang menikmati setiap pekerjaan yang telah saya lakukan diluar daerah, karena saya jarang memperoleh uang perjalanan dinas

\begin{tabular}{|c|c|c|c|}
\hline SS & S & TS & STS \\
& & & \\
\hline
\end{tabular}

21. Saya sangat terbantu menyelesaikan pekerjaan dengan cepat, karena tersedianya komputer dan laptop ditempat saya bekerja

\begin{tabular}{|c|c|c|c|}
\hline SS & S & TS & STS \\
& & & \\
\hline
\end{tabular}


22. Saya dan rekan kerja saya, merasa kesulitan memeriksa kesehatan masyarakat karena alatalat kesehatan seperti suntikan dan obat-obatan yang tersedia ditempat kami bekerja, tidak mencukupi untuk digunakan pada rekan kerja yang lainnya

23. Saya dan rekan kerja saya merasa kesusahan dalam menjalankan tugas keluar Kabupaten, karena ketersediaan kendaraan dinas yang kurang mencukupi di tempat kami bekerja

\begin{tabular}{|l|l|l|l|}
\hline SS & S & TS & STS \\
& & & \\
& & & \\
\hline
\end{tabular}

\begin{tabular}{|c|c|c|c|}
\hline SS & S & TS & STS \\
& & & \\
& & & \\
\hline
\end{tabular}

24. Desain ventilasi diruangan saya bekerja, membuat saya tidak nyaman dalam bekerja

\begin{tabular}{|c|c|c|c|}
\hline SS & S & TS & STS \\
\hline
\end{tabular}

25. Saya merasa terbantu dengan adanya $\mathrm{Wi}-\mathrm{f} i$ ditempat saya bekerja untuk dapat menyelesaikan segala tugas yang berhubungan dengan internet

\begin{tabular}{|c|c|c|c|}
\hline SS & S & TS & STS \\
& & & \\
& & & \\
\hline
\end{tabular}

26. Apabila saya membuat kesalahan dalam bekerja, rekan kerja saya membiarkan saya untuk memperbaiki sendiri pekerjaan itu

\begin{tabular}{|l|l|l|l|}
\hline SS & S & TS & STS \\
& & & \\
& & & \\
\hline
\end{tabular}

27. Saya dan rekan kerja saya, kurang kompak dalam menjalankan setiap pekerjaan yang diberikan pada kami setiap harinya

\begin{tabular}{|c|c|c|c|}
\hline SS & S & TS & STS \\
& & & \\
\hline
\end{tabular}

28. Bagi saya, dengan dipindahkannya saya kebagian yang lain merupakan hambatan atas pekerjaan yang akan saya lakukan

\begin{tabular}{|c|c|c|c|}
\hline SS & S & TS & STS \\
& & & \\
\hline
\end{tabular}


29. Saya tidak pernah berkesempatan dalam promosi

\begin{tabular}{|c|c|c|c|}
\hline SS & S & TS & STS \\
& & & \\
\hline
\end{tabular}

30. Alat kesehatan suntik dan obat-obatan yang telah

\begin{tabular}{|c|c|c|c|}
\hline SS & S & TS & STS \\
& & & \\
& & & \\
\hline
\end{tabular}
yang terbaik kepada masyarakat 


\section{SKALA II MOTIVASI KERJA}

No.

\section{Pernyataan}

1. Saya semangat kerja, ketika imbalan jasa yang saya terima diberikan dengan tepat waktu

2. Pembayaran gaji yang saya terima, berjalan dengan baik dan mencukupi untuk kebutuhan sehari-hari saya

3. Gaji yang telah saya terima, sudah sesuai dengan pekerjaan yang telah saya lakukan

4. Apabila gaji yang diberikan pada saya tidak sesuai harapan, bagi saya pekerjaan itu sia-sia

5. Saya bekerja hanya demi untuk mendapatkan gaji

6. Saya malas bekerja, jika tidak mendapatkan gaji yang banyak jumlahnya

7. Atasan saya memberikan bimbingan yang baik atas pekerjaan yang akan saya lakukan

8. Atasan saya selalu sabar untuk membimbing saya pada saat saya sedang mengalami kesulitan dalam menjalankan pekerjaan

9 Kemajuan saya dalam penyelesaian tugas, itu karena berkat dukungan dari atasan saya
Alternatif Jawaban

\begin{tabular}{|l|l|l|l|}
\hline SS & S & TS & STS \\
& & & \\
\hline
\end{tabular}

\begin{tabular}{|c|c|c|c|}
\hline SS & S & TS & STS \\
& & & \\
\hline
\end{tabular}

\begin{tabular}{|l|l|l|l|}
\hline SS & S & TS & STS \\
\hline
\end{tabular}

\begin{tabular}{|l|l|l|l|}
\hline SS & S & TS & STS \\
\hline
\end{tabular}

\begin{tabular}{|c|c|c|c|}
\hline SS & S & TS & STS \\
\hline
\end{tabular}

\begin{tabular}{|c|c|c|c|}
\hline SS & S & TS & STS \\
\hline
\end{tabular}

\begin{tabular}{|l|l|l|l|}
\hline SS & S & TS & STS \\
\hline
\end{tabular}

\begin{tabular}{|c|c|c|c|}
\hline SS & S & TS & STS \\
& & & \\
\hline
\end{tabular}

\begin{tabular}{|l|l|l|l|}
\hline SS & S & TS & STS \\
\hline
\end{tabular}


langsung

10 Saya malas menjalankan pekerjaan, jika atasan saya tidak memberi bimbingan pada saya

11. Atasan tidak pernah mendukung langsung saya akan pekerjaan yang saya lakukan

12. Kerjasama dengan rekan kerja saya, membuat pekerjaan cepat terselesaikan

13. Saya dan rekan kerja saya, saling bekerja sama dalam menjalankan setiap tugas yang diberikan pada kami sehari-hari

14. Saya merasa atasan saya pilih kasih pada rekan kerja yang lainnya atas perbedaan pencapaian prestasi kerja yang masingmasing kami dapatkan

15. Pekerjaan terasa ringan, jika saya dan rekan kerja saya bekerja sama menjalankan pekerjaan yang diberikan pada kami

16. Saya dan rekan kerja saya kurang dalam berkomunikasi disetiap menjalankan tugas sehari-hari

17. Pegawai yang melanggar peraturan yang berlaku di tempat saya bekerja, tidak diberikan hukuman yang setimpal

18. Peraturan yang ada ditempat saya bekerja,

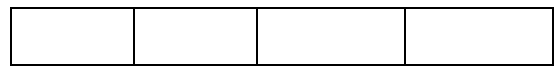

\begin{tabular}{|l|l|l|l|}
\hline SS & S & TS & STS \\
& & & \\
\hline
\end{tabular}

\begin{tabular}{|l|l|l|l|} 
SS & S & TS & STS \\
\end{tabular}

\begin{tabular}{|l|l|l|l|}
\hline SS & S & TS & STS \\
\hline
\end{tabular}

\begin{tabular}{|c|c|c|c|}
\hline SS & S & TS & STS \\
& & & \\
\hline
\end{tabular}

\begin{tabular}{|c|c|c|c|}
\hline SS & S & TS & STS \\
& & & \\
& & & \\
\hline
\end{tabular}

\begin{tabular}{|c|c|c|c|}
\hline SS & S & TS & STS \\
& & & \\
\hline
\end{tabular}

\begin{tabular}{|l|l|l|l|}
\hline SS & S & TS & STS \\
& & & \\
\hline
\end{tabular}

\begin{tabular}{|c|c|c|c|}
\hline SS & S & TS & STS \\
& & & \\
\hline
\end{tabular}

\begin{tabular}{|l|l|l|l|}
\hline SS & S & TS & STS \\
\hline
\end{tabular}


diberlakukan secara adil

19. Peraturan yang dibuat di Instansi saya bekerja, sudah sesuai dengan yang telah ditetapkan oleh pemerintah

20. Saya merasa kesulitan bekerja, jika rekan kerja saya tidak berpartisipasi dalam menjelaskan tugas yang telah dberikan pada kami

21. Saya dan rekan kerja saya jarang mengikuti seluruh kegiatan yang ada ditempat kami bekerja

22. Peraturan yang ada ditempat saya bekerja, tidak diberlakukan secara konsisten

23. Banyaknya pekerjaan yang akan saya lakukan, membuat saya menjadi malas menyelesaikannya

24. Saya merasa terganggu bekerja, karena adanya cctv ditempat saya bekerja

25. Pekerjaan yang telah saya kerjakan, sesuai dengan kemampuan yang saya miliki

26. Saya dan rekan kerja saya akan cemas bekerja, apabila terjadi kemalangan kebakaran ditempat kami bekerja dan alat pemadam api yang ada ditempat kami bekerja

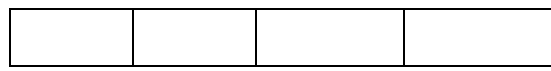

\begin{tabular}{|l|l|l|l|}
\hline SS & S & TS & STS \\
& & & \\
\hline
\end{tabular}

\begin{tabular}{|c|c|c|c|}
\hline SS & S & TS & STS \\
& & & \\
\hline
\end{tabular}

\begin{tabular}{|c|c|c|c|}
\hline SS & S & TS & STS \\
& & & \\
\hline
\end{tabular}

\begin{tabular}{|c|c|c|c|}
\hline SS & S & TS & STS \\
\hline
\end{tabular}

\begin{tabular}{|l|l|l|l|}
\hline SS & S & TS & STS \\
& & & \\
\hline
\end{tabular}

\begin{tabular}{|l|l|l|l|}
\hline SS & S & TS & STS \\
& & & \\
\hline
\end{tabular}

\begin{tabular}{|l|l|l|l|}
\hline SS & S & TS & STS \\
& & & \\
\hline
\end{tabular}

\begin{tabular}{|l|l|l|l|}
\hline SS & S & TS & STS \\
& & & \\
\hline
\end{tabular}


tidak dapat berfungsi

27. Atasan selalu sabar untuk membimbing saya pada saat saya sedang mengalami kesulitan dalam menjalankan tugas

28. Pekerjaan yang banyak, sangat menghambat Saya untuk menyelesaikan pekerjaan

29. Saya merasa aman karena adanya brankas diruang kerja saya, untuk menyimpan file-file dan berkas lainnya yang sangat penting

30 Saya tidak khawatir dengan berkas yang terletak diruang meja saya, karena jendela dan pintu yang ada diruangan saya bekerja, ditutup dan digembok dengan bagus

31 Adanya security ditempat saya bekerja, membuat saya merasa aman disetiap menjalankan tugas

32 Saya dan rekan kerja saya cemas akan berkas kerja kami masing-masing, karena kami masing-masing memiliki lemari dan kunci yang sama

33. Semua pekerjaan yang diberikan pada saya, sesuai dengan minat dan bakat yang saya miliki

34. Saya sangat terhambat dalam menjalankan pekerjaan dengan maksimal

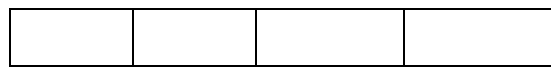

\begin{tabular}{|l|l|l|l|}
\hline SS & S & TS & STS \\
& & & \\
\hline
\end{tabular}

\begin{tabular}{|l|l|l|l|}
\hline SS & S & TS & STS \\
\hline
\end{tabular}

\begin{tabular}{|c|c|c|c|}
\hline SS & S & TS & STS \\
& & & \\
\hline
\end{tabular}

\begin{tabular}{|c|c|c|c|}
\hline SS & S & TS & STS \\
& & & \\
\hline
\end{tabular}

\begin{tabular}{|c|c|c|c|}
\hline SS & S & TS & STS \\
& & & \\
\hline
\end{tabular}

\begin{tabular}{|c|c|c|c|}
\hline SS & S & TS & STS \\
& & & \\
\hline
\end{tabular}

\begin{tabular}{|c|c|c|c|}
\hline SS & S & TS & STS \\
& & & \\
\hline
\end{tabular}

\begin{tabular}{|l|l|l|l|}
\hline SS & S & TS & STS \\
& & & \\
\hline
\end{tabular}


35. Hasil pekerjaan yang telah saya lakukan, mencapai kinerja yang baik

\begin{tabular}{|c|c|c|c|}
\hline SS & S & TS & STS \\
\hline
\end{tabular}

36. Kemampuan kerja yang telah saya lakukan setiap harinya, membuat hasil kinerja saya meningkat

\begin{tabular}{|c|c|c|c|}
\hline SS & S & TS & STS \\
& & & \\
\hline
\end{tabular}

37. Saya bangga akan setiap keputusan baik yang telah saya lakukan dalam setiap menjalankan tugas, karena itu merupakan cara saya meningkatkan kinerja

\begin{tabular}{|l|l|l|l|}
\hline SS & S & TS & STS \\
& & & \\
& & & \\
\hline
\end{tabular}

38. Penilian pretasi kerja setiap pegawai ditempat saya bekerja, dilakukan dengan kurang teliti

\begin{tabular}{|l|l|l|l|}
\hline SS & S & TS & STS \\
\hline
\end{tabular}

39. Prestasi kerja yang saya dapat ditempat saya bekerja, tidak sesuai akan pekerjaan yang telah saya laksanakan setiap harinya

\begin{tabular}{|l|l|l|l|}
\hline SS & S & TS & STS \\
& & & \\
\hline
\end{tabular}

40. Saya malas bekerja jika mendapatkan pretasi kerja yang buruk

\begin{tabular}{|l|l|l|l|}
\hline SS & S & TS & STS \\
& & & \\
\hline
\end{tabular}

41. Saya tetap percaya diri dengan semua pekerjaan yang saya lakukan

\begin{tabular}{|c|c|c|c|}
\hline SS & S & TS & STS \\
\hline
\end{tabular}

42. Saya bangga dengan kenaikan pangkat yang saya inginkan, akan prestasi kerja saya yang memuaskan

\begin{tabular}{|c|c|c|c|}
\hline SS & S & TS & STS \\
& & & \\
\hline
\end{tabular}

43. Saya berusaha menyelesaikan pekerjaan

\begin{tabular}{|l|l|l|l|}
\hline SS & S & TS & STS \\
\hline
\end{tabular}


terlebih dahulu sebelum jam pulang kerja

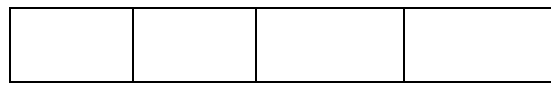

44. Saya tidak mampu menyelesaikan pekerjaan yang sulit untuk mencapai kinerja yang maksimal

\begin{tabular}{|c|c|c|c|}
\hline SS & S & TS & STS \\
& & & \\
\hline
\end{tabular}

45. Pekerjaan yang telah saya lakukan, membuat hasil prestasi kerja saya lebih buruk

\begin{tabular}{|c|c|c|c|}
\hline SS & S & TS & STS \\
\hline
\end{tabular}

46. Saya sering absen dipekerjaan dengan alasan yang tidak benar

\begin{tabular}{|c|c|c|c|}
\hline SS & S & TS & STS \\
\hline
\end{tabular}

47. Saya menjalankan setiap tugas yang diberikan pada saya dengan senang hati

\begin{tabular}{|l|l|l|l|}
\hline SS & S & TS & STS \\
\hline
\end{tabular}

48. Saya berada ditempat kerja, pada saat jam kerja berlangsung

\begin{tabular}{|c|c|c|c|}
\hline SS & S & TS & STS \\
\hline
\end{tabular}

49. Saya bekerja keras untuk memperoleh kinerja yang lebih baik

\begin{tabular}{|l|l|l|l|}
\hline SS & S & TS & STS \\
& & & \\
\hline
\end{tabular}

50. Saya tidak mampu menjelaskan pekerjaan yang telah saya lakukan, jika atasan meminta saya untuk menjelaskannya

\begin{tabular}{|l|l|l|l|}
\hline SS & S & TS & STS \\
& & & \\
\hline
\end{tabular}

51. Saya mudah lelah ketika jam kerja sedang berlangsung

\begin{tabular}{|l|l|l|l|}
\hline SS & S & TS & STS \\
& & & \\
\hline
\end{tabular}

52. Apabila prestasi kerja saya jelek, itu akan membuat saya menjadi malas untuk bekerja

\begin{tabular}{|l|l|l|l|}
\hline SS & S & TS & STS \\
& & & \\
\hline
\end{tabular}


dengan semangat

53. Bekerja di Instansi ini, saya merasa kemampuan saya berkembang

54. Bekerja di Instansi ini, saya merasa pengalaman dan keahlian yang saya miliki semakin berkembang

55. Pekerjaan yang telah saya lakukan, memungkin saya untuk dapat naik jabatan ditempat saya bekerja

56. Saya tidak berkesempatan untuk mengembangkan kemampuan dan keterampilan kerja yang saya miliki ditempat saya bekerja

57. Saya merasa kesusahan dalam bekerja dengan adanya pelatihan-pelatihan yang harus diikuti berasamaan dengan waktu jam bekerja saya

58. Saya tidak berkesempatan untuk belajar halhal baru yang ada ditempat saya bekerja

59. Saya senang dapat mengembangkan kemampuan dan keterampilan saya selama bekerja di Instansi ini

60. Pekerjaan yang saya lakukan setiap harinya,

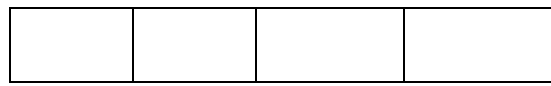

\begin{tabular}{|l|l|l|l|}
\hline SS & S & TS & STS \\
\hline
\end{tabular}

\begin{tabular}{|l|l|l|l|}
\hline SS & S & TS & STS \\
& & & \\
\hline
\end{tabular}

\begin{tabular}{|c|c|c|c|}
\hline SS & S & TS & STS \\
& & & \\
\hline
\end{tabular}

\begin{tabular}{|c|c|c|c|}
\hline SS & S & TS & STS \\
& & & \\
\hline
\end{tabular}

\begin{tabular}{|l|l|l|l|}
\hline SS & S & TS & STS \\
& & & \\
\hline
\end{tabular}

\begin{tabular}{|c|c|c|c|}
\hline SS & S & TS & STS \\
& & & \\
\hline
\end{tabular}

\begin{tabular}{|c|c|c|c|}
\hline SS & S & TS & STS \\
& & & \\
\hline
\end{tabular}

\begin{tabular}{|l|l|l|l|}
\hline SS & S & TS & STS \\
\hline
\end{tabular}


memungkinkan saya untuk memiliki pengalaman dan keahlian yang berharga

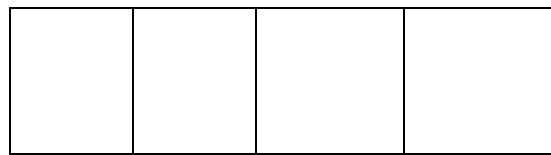

61. Saya bangga bekerja di Instansi ini, karena saya merasa dapat tumbuh dan berkembang sebagai seorang individu yang ingin memiliki keahlian dalam bekerja

\begin{tabular}{|c|c|c|c|}
\hline SS & S & TS & STS \\
& & & \\
\hline
\end{tabular}

62. Saya kurang puas dengan tidak dapat berkembangnya karir saya di Instansi ini

\begin{tabular}{|c|c|c|c|}
\hline SS & S & TS & STS \\
\hline
\end{tabular}

63. Saya lebih memilih insetif uang dibandingkan pengembangan karir yang saya miliki

\begin{tabular}{|l|l|l|l|}
\hline SS & S & TS & STS \\
\hline
\end{tabular}

64. Saya tidak giat dalam bekerja, karena Instansi tidak ada memberi kesempatan pada saya untuk dapat menduduki posisi tertentu

\begin{tabular}{|c|c|c|c|}
\hline SS & S & TS & STS \\
& & & \\
\hline
\end{tabular}

65. Bagi saya menjalankan pekerjaan yang baru adalah suatu tantangan

\begin{tabular}{|l|l|l|l|}
\hline SS & S & TS & STS \\
\hline
\end{tabular}

66. Apabila saya diberikan tugas yang baru, bagi saya itu merupakan wawasan yang luas bagi saya

\begin{tabular}{|l|l|l|l|}
\hline SS & S & TS & STS \\
& & & \\
\hline
\end{tabular}

67. Apabila saya diberikan tugas yang baru, bagi saya itu merupakan kepercayaan atasan atas kemampuan yang saya miliki

\begin{tabular}{|l|l|l|l|}
\hline SS & S & TS & STS \\
& & & \\
\hline
\end{tabular}


68. Saya malas memperbaiki pekerjaan saya yang salah

\begin{tabular}{|l|l|l|l|}
\hline SS & S & TS & STS \\
\hline
\end{tabular}

69. Apabila saya sedang kurang enak badan, saya

\begin{tabular}{|l|l|l|l|}
\hline SS & S & TS & STS \\
& & & \\
\hline
\end{tabular}

70. Saya takut akan tidak terselesaikannya pekerjaan yang diberikan pada saya, karena waktu penyelesaiannya sudah ditentukan

\begin{tabular}{|l|l|l|l|}
\hline SS & S & TS & STS \\
& & & \\
\hline
\end{tabular}




\section{LAMPIRAN B}

Data Kepuasan Kerja Sebelum dan Sesudah Uji

Coba 


\begin{tabular}{|c|c|c|c|c|c|c|c|c|}
\hline \multicolumn{9}{|c|}{ NO } \\
\hline 1 & 2 & 3 & 4 & 5 & 6 & 7 & \multicolumn{2}{|l|}{8} \\
\hline 1 & 3 & 3 & 4 & 3 & 3 & 3 & 4 & 3 \\
\hline 2 & 4 & 4 & 4 & 4 & 4 & 4 & 4 & 3 \\
\hline 3 & 3 & 3 & 3 & 3 & 3 & 3 & 3 & 3 \\
\hline 4 & 3 & 3 & 4 & 3 & 3 & 3 & 4 & 3 \\
\hline 5 & 3 & 3 & 3 & 3 & 2 & 3 & 3 & 3 \\
\hline 6 & 4 & 3 & 3 & 4 & 3 & 3 & 4 & 3 \\
\hline 7 & 3 & 3 & 4 & 4 & 3 & 3 & 4 & 3 \\
\hline 8 & 4 & 2 & 4 & 4 & 4 & 4 & 4 & 3 \\
\hline 9 & 4 & 4 & 4 & 4 & 4 & 4 & 4 & 4 \\
\hline 10 & 3 & 3 & 4 & 4 & 4 & 4 & 4 & 3 \\
\hline 11 & 3 & 4 & 4 & 3 & 4 & 3 & 3 & 3 \\
\hline 12 & 4 & 4 & 4 & 4 & 4 & 4 & 4 & 4 \\
\hline 13 & 4 & 4 & 4 & 4 & 4 & 4 & 4 & 4 \\
\hline 14 & 4 & 4 & 4 & 4 & 4 & 4 & 4 & 4 \\
\hline 15 & 3 & 3 & 4 & 4 & 3 & 3 & 4 & 3 \\
\hline 16 & 4 & 4 & 4 & 4 & 4 & 4 & 4 & 3 \\
\hline 17 & 4 & 4 & 4 & 4 & 4 & 3 & 4 & 3 \\
\hline 18 & 4 & 4 & 4 & 4 & 4 & 4 & 4 & 3 \\
\hline 19 & 3 & 4 & 3 & 4 & 4 & 2 & 3 & 3 \\
\hline 20 & 3 & 3 & 4 & 3 & 4 & 3 & 2 & 2 \\
\hline 21 & 4 & 4 & 4 & 3 & 3 & 4 & 4 & 3 \\
\hline 22 & 4 & 4 & 3 & 4 & 4 & 2 & 3 & 3 \\
\hline 23 & 3 & 3 & 4 & 3 & 4 & 4 & 4 & 3 \\
\hline 24 & 4 & 4 & 4 & 4 & 4 & 4 & 3 & 3 \\
\hline 25 & 3 & 4 & 3 & 4 & 4 & 4 & 3 & 4 \\
\hline 26 & 4 & 4 & 4 & 4 & 4 & 4 & 3 & 3 \\
\hline 27 & 4 & 4 & 3 & 3 & 2 & 3 & 3 & 3 \\
\hline 28 & 4 & 4 & 4 & 4 & 4 & 4 & 3 & 3 \\
\hline 29 & 4 & 3 & 3 & 3 & 3 & 4 & 3 & 3 \\
\hline 30 & 4 & 4 & 4 & 4 & 4 & 4 & 4 & 4 \\
\hline 31 & 4 & 3 & 3 & 4 & 4 & 4 & 4 & 4 \\
\hline 32 & 4 & 4 & 3 & 4 & 4 & 2 & 3 & 3 \\
\hline 33 & 3 & 3 & 3 & 4 & 4 & 2 & 3 & 3 \\
\hline 34 & 3 & 3 & 3 & 3 & 3 & 3 & 2 & 2 \\
\hline 35 & 3 & 4 & 3 & 3 & 3 & 2 & 3 & 3 \\
\hline 36 & 3 & 3 & 3 & 4 & 4 & 3 & 4 & 4 \\
\hline 37 & 4 & 3 & 4 & 4 & 4 & 4 & 4 & 3 \\
\hline 38 & 4 & 4 & 3 & 4 & 4 & 2 & 3 & 3 \\
\hline 39 & 3 & 3 & 3 & 4 & 4 & 2 & 3 & 3 \\
\hline 40 & 3 & 3 & 4 & 4 & 4 & 2 & 3 & 3 \\
\hline 41 & 3 & 3 & 3 & 4 & 3 & 3 & 4 & 3 \\
\hline 42 & 3 & 3 & 4 & 3 & 3 & 2 & 3 & 3 \\
\hline
\end{tabular}




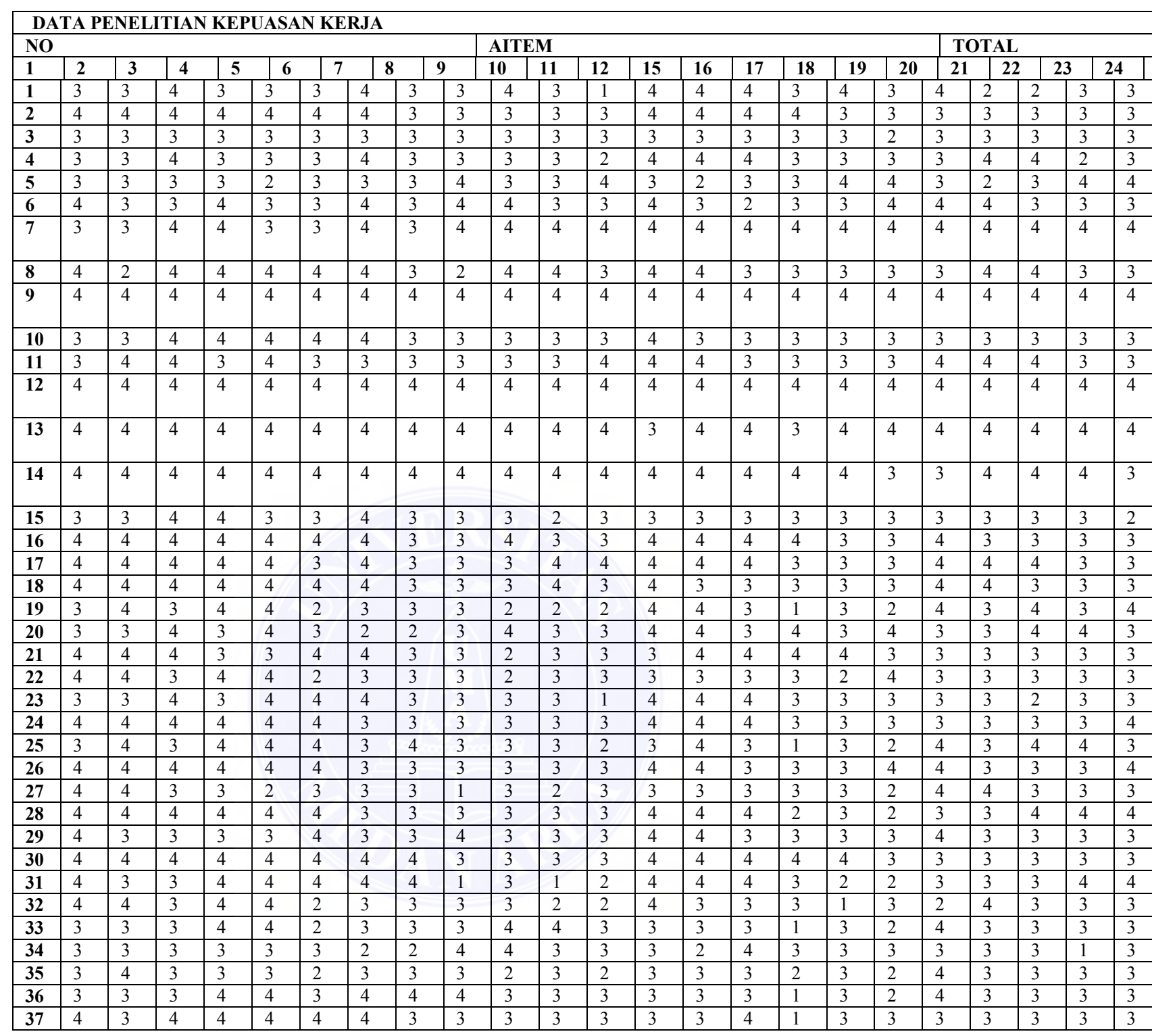




\section{LAMPIRAN C}

\section{Data Motivasi Kerja Sebelum dan Sesudah Uji}

Coba 


\begin{tabular}{|c|c|c|c|c|c|c|c|c|}
\hline \multicolumn{9}{|c|}{ NO } \\
\hline 1 & 2 & 3 & & & 5 & 6 & 7 & 8 \\
\hline 1 & 3 & 3 & 3 & 3 & 3 & 2 & \begin{tabular}{l|l} 
& 1
\end{tabular} & 4 \\
\hline 2 & 3 & 4 & 4 & 4 & 3 & 3 & 2 & 4 \\
\hline 3 & 4 & 4 & 3 & 4 & 4 & 4 & 2 & 3 \\
\hline 4 & 4 & 4 & 4 & 4 & 4 & 3 & 2 & 3 \\
\hline 5 & 3 & 3 & 3 & 3 & 3 & 3 & 4 & 3 \\
\hline 6 & 3 & 3 & 3 & 3 & 3 & 3 & 1 & 4 \\
\hline 7 & 4 & 4 & 4 & 3 & 4 & 3 & 3 & 2 \\
\hline 8 & 3 & 3 & 3 & 3 & 4 & 3 & 3 & 2 \\
\hline 9 & 4 & 4 & 3 & 3 & 4 & 4 & 2 & 3 \\
\hline 10 & 3 & 3 & 3 & 3 & 3 & 2 & 2 & 3 \\
\hline 11 & 3 & 3 & 3 & 3 & 3 & 3 & 2 & 3 \\
\hline 12 & 4 & 4 & 4 & 4 & 3 & 3 & 3 & 2 \\
\hline 13 & 3 & 3 & 3 & 4 & 2 & 2 & 4 & 3 \\
\hline 14 & 4 & 4 & 3 & 4 & 3 & 1 & 3 & 3 \\
\hline 15 & 3 & 3 & 4 & 3 & 3 & 3 & 3 & 2 \\
\hline 16 & 3 & 3 & 4 & 3 & 2 & 2 & 4 & 4 \\
\hline 17 & 4 & 3 & 3 & 2 & 2 & 3 & 3 & 3 \\
\hline 18 & 3 & 3 & 3 & 3 & 3 & 1 & 4 & 3 \\
\hline 19 & 3 & 3 & 3 & 3 & 3 & 3 & 1 & 4 \\
\hline 20 & 3 & 3 & 3 & 2 & 2 & 4 & 4 & 3 \\
\hline 21 & 3 & 3 & 3 & 4 & 4 & 3 & 2 & 2 \\
\hline 22 & 4 & 4 & 3 & 3 & 4 & 2 & 3 & 4 \\
\hline 23 & 3 & 3 & 4 & 4 & 3 & 2 & 3 & 3 \\
\hline 24 & 4 & 4 & 3 & 3 & 2 & 3 & 3 & 3 \\
\hline 25 & 3 & 3 & 4 & 3 & 4 & 4 & 4 & 4 \\
\hline 26 & 3 & 3 & 3 & 3 & 2 & 2 & 4 & 3 \\
\hline 27 & 4 & 4 & 4 & 4 & 4 & 3 & 2 & 4 \\
\hline 28 & 3 & 3 & 3 & 3 & 3 & 3 & 3 & 3 \\
\hline 29 & 4 & 4 & 3 & 2 & 2 & 4 & 4 & 3 \\
\hline 30 & 3 & 3 & 3 & 3 & 3 & 3 & 3 & 3 \\
\hline 31 & 3 & 4 & 4 & 3 & 3 & 3 & 3 & 2 \\
\hline 32 & 3 & 3 & 3 & 2 & 2 & 3 & 3 & 4 \\
\hline 33 & 3 & 3 & 4 & 3 & 4 & 2 & 2 & 3 \\
\hline 34 & 4 & 4 & 3 & 3 & 2 & 4 & 3 & 3 \\
\hline 35 & 3 & 3 & 3 & 2 & 2 & 4 & 4 & 3 \\
\hline 36 & 3 & 3 & 3 & 3 & 3 & 3 & 4 & 4 \\
\hline 37 & 4 & 4 & 4 & 4 & 4 & 2 & 1 & 3 \\
\hline 38 & 3 & 3 & 3 & 4 & 4 & 2 & 3 & 3 \\
\hline 39 & 3 & 3 & 3 & 3 & 2 & 1 & 4 & 3 \\
\hline 40 & 4 & 4 & 4 & 3 & 3 & 3 & 2 & 2 \\
\hline 41 & 4 & 4 & 4 & 3 & 4 & 3 & 3 & 3 \\
\hline 42 & 4 & 4 & 3 & 4 & 3 & 3 & 2 & 2 \\
\hline
\end{tabular}




\begin{tabular}{|c|c|c|c|c|c|c|c|c|}
\hline 43 & 3 & 3 & 3 & 3 & 2 & 4 & 3 & 3 \\
\hline 44 & 4 & 4 & 4 & 4 & 4 & 3 & 4 & 4 \\
\hline 45 & 4 & 4 & 4 & 4 & 3 & 3 & 4 & 2 \\
\hline 46 & 3 & 3 & 3 & 4 & 4 & 4 & 3 & 1 \\
\hline 47 & 3 & 3 & 3 & 2 & 3 & 4 & 3 & 2 \\
\hline 48 & 4 & 3 & 3 & 4 & 3 & 2 & 2 & 4 \\
\hline 49 & 3 & 3 & 3 & 3 & 2 & 2 & 4 & 3 \\
\hline 50 & 4 & 4 & 4 & 4 & 4 & 4 & 4 & 4 \\
\hline 51 & 3 & 3 & 3 & 4 & 4 & 1 & 3 & 3 \\
\hline 52 & 4 & 4 & 3 & 3 & 3 & 3 & 3 & 3 \\
\hline 53 & 4 & 4 & 3 & 4 & 2 & 2 & 3 & 3 \\
\hline 54 & 3 & 3 & 3 & 3 & 3 & 3 & 4 & 4 \\
\hline 55 & 4 & 4 & 3 & 4 & 2 & 3 & 3 & 3 \\
\hline 54 & 3 & 4 & 2 & 1 & 4 & 3 & 3 & 4 \\
\hline 57 & 3 & 3 & 4 & 4 & 3 & 3 & 3 & 3 \\
\hline 58 & 3 & 3 & 3 & 2 & 3 & 3 & 1 & 4 \\
\hline 59 & 4 & 4 & 3 & 1 & 2 & 3 & 3 & 3 \\
\hline 60 & 3 & 3 & 2 & 3 & 3 & 3 & 3 & 3 \\
\hline 61 & 4 & 4 & 3 & 1 & 3 & 2 & 3 & 4 \\
\hline 62 & 3 & 3 & 3 & 3 & 3 & 1 & 3 & 3 \\
\hline 63 & 3 & 3 & 3 & 1 & 4 & 3 & 3 & 2 \\
\hline 64 & 4 & 4 & 3 & 2 & 2 & 3 & 3 & 4 \\
\hline 65 & 3 & 3 & 4 & 3 & 2 & 2 & 4 & 4 \\
\hline 66 & 3 & 3 & 3 & 3 & 3 & 4 & 2 & 3 \\
\hline 67 & 4 & 3 & 3 & 3 & 3 & 2 & 2 & 4 \\
\hline 68 & 4 & 4 & 3 & 3 & 2 & 2 & 3 & 3 \\
\hline 69 & 3 & 3 & 3 & 4 & 2 & 2 & 4 & 4 \\
\hline 70 & 4 & 4 & 3 & 3 & 3 & 2 & 2 & 3 \\
\hline 71 & 3 & 3 & 3 & 3 & 2 & 3 & 4 & 4 \\
\hline 72 & 3 & 3 & 3 & 2 & 1 & 3 & 3 & 3 \\
\hline 73 & 3 & 3 & 4 & 3 & 2 & 3 & 2 & 3 \\
\hline 74 & 4 & 3 & 3 & 3 & 1 & 4 & 4 & 4 \\
\hline 75 & 3 & 3 & 3 & 3 & 2 & 2 & 3 & 4 \\
\hline 76 & 4 & 4 & 3 & 2 & 2 & 4 & 4 & 3 \\
\hline 77 & 3 & 3 & 3 & 3 & 3 & 3 & 3 & 3 \\
\hline 78 & 3 & 3 & 4 & 3 & 1 & 2 & 4 & 4 \\
\hline 79 & 3 & 3 & 3 & 3 & 2 & 2 & 3 & 3 \\
\hline 80 & 3 & 3 & 3 & 3 & 3 & 3 & 3 & 3 \\
\hline 81 & 3 & 4 & 4 & 1 & 3 & 2 & 4 & 4 \\
\hline 82 & 3 & 3 & 4 & 3 & 1 & 2 & 4 & 4 \\
\hline 83 & 4 & 3 & 2 & 1 & 3 & 3 & 3 & 3 \\
\hline 84 & 4 & 4 & 3 & 2 & 2 & 3 & 3 & 3 \\
\hline 85 & 4 & 3 & 3 & 2 & 2 & 4 & 3 & 3 \\
\hline 86 & 3 & 3 & 3 & 1 & 3 & 3 & 4 & 2 \\
\hline
\end{tabular}




\begin{tabular}{|c|c|c|c|c|c|c|c|c|}
\hline 9 & 10 & 11 & 12 & 13 & 14 & 15 & 16 & 17 \\
\hline 3 & 4 & 3 & 4 & 3 & 3 & 3 & 4 & 2 \\
\hline 4 & 3 & 3 & 4 & 3 & 3 & 3 & 4 & 3 \\
\hline 4 & 4 & 4 & 4 & 3 & 3 & 3 & 3 & 2 \\
\hline 3 & 3 & 3 & 3 & 4 & 4 & 3 & 3 & 2 \\
\hline 3 & 3 & 4 & 4 & 4 & 3 & 3 & 3 & 3 \\
\hline 3 & 4 & 3 & 4 & 4 & 4 & 4 & 2 & 3 \\
\hline 3 & 4 & 4 & 4 & 4 & 4 & 3 & 3 & 3 \\
\hline 3 & 3 & 4 & 4 & 4 & 4 & 3 & 3 & 3 \\
\hline 3 & 3 & 3 & 3 & 3 & 3 & 3 & 3 & 3 \\
\hline 3 & 4 & 4 & 4 & 3 & 3 & 3 & 4 & 3 \\
\hline 4 & 3 & 4 & 4 & 3 & 3 & 3 & 4 & 2 \\
\hline 3 & 3 & 4 & 4 & 3 & 3 & 3 & 2 & 3 \\
\hline 3 & 3 & 4 & 4 & 3 & 2 & 3 & 4 & 4 \\
\hline 4 & 4 & 4 & 3 & 2 & 2 & 4 & 3 & 3 \\
\hline 2 & 3 & 3 & 4 & 4 & 4 & 3 & 3 & 3 \\
\hline 4 & 4 & 4 & 3 & 3 & 3 & 3 & 2 & 4 \\
\hline 3 & 3 & 3 & 4 & 4 & 4 & 4 & 3 & 3 \\
\hline 3 & 3 & 3 & 3 & 3 & 3 & 4 & 2 & 4 \\
\hline 4 & 4 & 3 & 3 & 3 & 4 & 4 & 2 & 3 \\
\hline 3 & 3 & 3 & 4 & 4 & 3 & 2 & 2 & 3 \\
\hline 3 & 3 & 3 & 3 & 3 & 4 & 4 & 3 & 3 \\
\hline 3 & 3 & 2 & 3 & 3 & 4 & 4 & 3 & 3 \\
\hline 4 & 4 & 3 & 3 & 3 & 3 & 4 & 4 & 1 \\
\hline 4 & 4 & 3 & 3 & 3 & 4 & 4 & 4 & 2 \\
\hline 3 & 3 & 3 & 3 & 2 & 2 & 3 & 3 & 3 \\
\hline 4 & 3 & 3 & 3 & 3 & 3 & 4 & 2 & 3 \\
\hline 3 & 4 & 3 & 4 & 3 & 3 & 3 & 4 & 2 \\
\hline 3 & 3 & 3 & 3 & 4 & 4 & 3 & 3 & 3 \\
\hline 3 & 3 & 3 & 3 & 3 & 4 & 4 & 2 & 4 \\
\hline 3 & 3 & 3 & 3 & 3 & 3 & 3 & 3 & 3 \\
\hline 2 & 4 & 4 & 4 & 4 & 4 & 4 & 4 & 3 \\
\hline 4 & 4 & 4 & 4 & 3 & 3 & 3 & 3 & 3 \\
\hline 4 & 4 & 3 & 3 & 3 & 3 & 4 & 4 & 4 \\
\hline 3 & 3 & 3 & 4 & 4 & 3 & 3 & 2 & 4 \\
\hline 3 & 3 & 3 & 3 & 3 & 3 & 3 & 3 & 3 \\
\hline 3 & 3 & 2 & 2 & 3 & 4 & 4 & 3 & 3 \\
\hline 3 & 4 & 3 & 3 & 3 & 4 & 2 & 3 & 4 \\
\hline 3 & 2 & 2 & 2 & 4 & 4 & 3 & 3 & 3 \\
\hline 4 & 3 & 3 & 4 & 4 & 3 & 3 & 2 & 3 \\
\hline 4 & 3 & 3 & 3 & 4 & 4 & 3 & 3 & 4 \\
\hline 3 & 3 & 3 & 2 & 2 & 4 & 4 & 3 & 3 \\
\hline 3 & 3 & 4 & 4 & 3 & 3 & 4 & 4 & 4 \\
\hline
\end{tabular}




\begin{tabular}{|c|c|c|c|c|c|c|c|c|}
\hline 4 & 4 & 4 & 4 & 4 & 3 & 2 & 3 & 4 \\
\hline 4 & 4 & 4 & 4 & 4 & 4 & 3 & 3 & 2 \\
\hline 2 & 3 & 4 & 4 & 4 & 3 & 3 & 3 & 3 \\
\hline 3 & 2 & 4 & 4 & 4 & 3 & 3 & 3 & 3 \\
\hline 3 & 3 & 3 & 4 & 4 & 3 & 3 & 2 & 3 \\
\hline 3 & 3 & 4 & 3 & 3 & 3 & 2 & 3 & 4 \\
\hline 3 & 4 & 3 & 3 & 1 & 3 & 3 & 4 & 4 \\
\hline 4 & 4 & 4 & 4 & 4 & 4 & 4 & 4 & 4 \\
\hline 3 & 3 & 3 & 3 & 2 & 2 & 4 & 4 & 3 \\
\hline 3 & 3 & 3 & 3 & 3 & 4 & 2 & 3 & 3 \\
\hline 3 & 3 & 2 & 4 & 4 & 4 & 4 & 3 & 3 \\
\hline 4 & 3 & 3 & 3 & 3 & 3 & 3 & 3 & 3 \\
\hline 3 & 3 & 2 & 3 & 3 & 3 & 3 & 3 & 4 \\
\hline 4 & 3 & 3 & 3 & 3 & 3 & 3 & 3 & 4 \\
\hline 2 & 3 & 4 & 4 & 3 & 3 & 3 & 2 & 3 \\
\hline 4 & 3 & 3 & 3 & 3 & 3 & 4 & 4 & 4 \\
\hline 4 & 4 & 4 & 4 & 3 & 3 & 3 & 3 & 4 \\
\hline 3 & 3 & 3 & 3 & 3 & 3 & 3 & 3 & 2 \\
\hline 3 & 3 & 3 & 3 & 3 & 3 & 4 & 4 & 4 \\
\hline 3 & 3 & 3 & 4 & 4 & 4 & 3 & 3 & 3 \\
\hline 3 & 3 & 3 & 4 & 4 & 4 & 3 & 3 & 3 \\
\hline 4 & 4 & 3 & 3 & 3 & 4 & 4 & 4 & 4 \\
\hline 3 & 3 & 3 & 3 & 3 & 4 & 4 & 4 & 3 \\
\hline 3 & 4 & 4 & 4 & 3 & 3 & 3 & 3 & 2 \\
\hline 3 & 4 & 4 & 3 & 3 & 3 & 4 & 2 & 3 \\
\hline 4 & 4 & 4 & 3 & 3 & 3 & 4 & 4 & 2 \\
\hline 3 & 3 & 4 & 4 & 4 & 3 & 3 & 3 & 2 \\
\hline 3 & 3 & 3 & 3 & 3 & 4 & 4 & 4 & 3 \\
\hline 3 & 3 & 3 & 3 & 4 & 4 & 4 & 2 & 2 \\
\hline 4 & 4 & 4 & 3 & 3 & 3 & 3 & 3 & 3 \\
\hline 3 & 3 & 3 & 4 & 4 & 4 & 3 & 3 & 1 \\
\hline 2 & 2 & 3 & 3 & 3 & 3 & 3 & 4 & 4 \\
\hline 4 & 3 & 3 & 3 & 4 & 4 & 4 & 3 & 3 \\
\hline 3 & 3 & 3 & 1 & 3 & 3 & 3 & 2 & 2 \\
\hline 4 & 4 & 4 & 3 & 3 & 3 & 4 & 2 & 4 \\
\hline 4 & 3 & 3 & 3 & 3 & 3 & 3 & 3 & 3 \\
\hline 3 & 3 & 3 & 3 & 3 & 3 & 3 & 3 & 3 \\
\hline 3 & 3 & 3 & 3 & 3 & 3 & 3 & 3 & 3 \\
\hline 4 & 4 & 4 & 4 & 4 & 4 & 4 & 3 & 3 \\
\hline 4 & 3 & 3 & 3 & 3 & 3 & 3 & 3 & 3 \\
\hline 4 & 4 & 4 & 3 & 3 & 3 & 3 & 3 & 3 \\
\hline 3 & 4 & 4 & 4 & 3 & 3 & 3 & 3 & 3 \\
\hline 3 & 3 & 3 & 3 & 3 & 3 & 3 & 4 & 4 \\
\hline 3 & 3 & 3 & 3 & 3 & 4 & 4 & 4 & $\overline{4}$ \\
\hline
\end{tabular}




\begin{tabular}{|c|c|c|c|c|c|c|c|c|}
\hline 18 & 19 & 20 & 21 & 22 & 23 & 24 & 25 & 26 \\
\hline 3 & 4 & 4 & 4 & 3 & 3 & 3 & 2 & 3 \\
\hline 3 & 3 & 3 & 3 & 3 & 3 & 3 & 3 & 3 \\
\hline 3 & 3 & 3 & 3 & 3 & 3 & 3 & 3 & 3 \\
\hline 3 & 3 & 3 & 4 & 4 & 4 & 4 & 3 & 3 \\
\hline 3 & 3 & 3 & 3 & 3 & 3 & 3 & 4 & 4 \\
\hline 3 & 3 & 4 & 4 & 3 & 3 & 2 & 3 & 4 \\
\hline 3 & 4 & 4 & 4 & 4 & 4 & 4 & 4 & 3 \\
\hline 3 & 3 & 4 & 4 & 4 & 3 & 3 & 3 & 4 \\
\hline 4 & 4 & 4 & 4 & 4 & 4 & 4 & 3 & 2 \\
\hline 4 & 4 & 4 & 3 & 3 & 3 & 3 & 3 & 4 \\
\hline 3 & 3 & 4 & 4 & 4 & 3 & 3 & 2 & 3 \\
\hline 4 & 4 & 3 & 3 & 3 & 2 & 3 & 4 & 4 \\
\hline 3 & 3 & 3 & 4 & 4 & 3 & 3 & 4 & 2 \\
\hline 3 & 3 & 3 & 4 & 4 & 4 & 4 & 4 & 4 \\
\hline 3 & 3 & 3 & 3 & 3 & 3 & 3 & 4 & 4 \\
\hline 3 & 1 & 3 & 3 & 4 & 4 & 4 & 4 & 4 \\
\hline 3 & 2 & 3 & 3 & 3 & 3 & 4 & 4 & 4 \\
\hline 4 & 4 & 3 & 3 & 3 & 4 & 4 & 4 & 3 \\
\hline 4 & 4 & 4 & 4 & 2 & 4 & 4 & 4 & 3 \\
\hline 3 & 3 & 3 & 3 & 3 & 3 & 3 & 3 & 4 \\
\hline 2 & 2 & 3 & 3 & 3 & 3 & 3 & 4 & 4 \\
\hline 2 & 3 & 3 & 2 & 2 & 4 & 4 & 3 & 3 \\
\hline 3 & 3 & 4 & 4 & 3 & 3 & 4 & 4 & 2 \\
\hline 2 & 4 & 4 & 3 & 3 & 3 & 4 & 4 & 4 \\
\hline 4 & 4 & 4 & 4 & 4 & 4 & 3 & 3 & 3 \\
\hline 4 & 4 & 4 & 3 & 3 & 3 & 2 & 3 & 4 \\
\hline 3 & 4 & 4 & 4 & 3 & 3 & 3 & 2 & 3 \\
\hline 4 & 4 & 4 & 3 & 2 & 2 & 4 & 4 & 3 \\
\hline 4 & 4 & 1 & 3 & 3 & 3 & 3 & 3 & 2 \\
\hline 3 & 3 & 3 & 2 & 2 & 4 & 4 & 3 & 3 \\
\hline 3 & 3 & 3 & 1 & 3 & 3 & 3 & 3 & 3 \\
\hline 3 & 4 & 1 & 3 & 3 & 3 & 3 & 3 & 2 \\
\hline 3 & 3 & 3 & 3 & 3 & 3 & 3 & 4 & 3 \\
\hline 4 & 4 & 4 & 4 & 4 & 4 & 4 & 3 & 3 \\
\hline 3 & 3 & 3 & 3 & 3 & 2 & 3 & 3 & 4 \\
\hline 4 & 4 & 4 & 3 & 3 & 3 & 4 & 4 & 1 \\
\hline 4 & 4 & 3 & 3 & 3 & 4 & 4 & 4 & 1 \\
\hline 1 & 3 & 2 & 4 & 3 & 3 & 3 & 3 & 3 \\
\hline 3 & 4 & 4 & 3 & 3 & 3 & 1 & 4 & 3 \\
\hline 4 & 4 & 3 & 3 & 2 & 3 & 4 & 4 & 3 \\
\hline 3 & 3 & 3 & 3 & 4 & 4 & 4 & 4 & 3 \\
\hline 3 & 3 & 3 & 3 & 4 & 4 & 4 & 2 & 2 \\
\hline
\end{tabular}




\begin{tabular}{|c|c|c|c|c|c|c|c|c|}
\hline 4 & 3 & 3 & 3 & 2 & 3 & 3 & 3 & 3 \\
\hline 2 & 4 & 4 & 3 & 3 & 3 & 4 & 4 & 4 \\
\hline 3 & 3 & 3 & 3 & 3 & 3 & 3 & 3 & 3 \\
\hline 3 & 3 & 3 & 4 & 4 & 4 & 3 & 3 & 3 \\
\hline 4 & 4 & 4 & 3 & 3 & 3 & 3 & 4 & 4 \\
\hline 4 & 4 & 3 & 3 & 3 & 3 & 3 & 3 & 3 \\
\hline 4 & 3 & 3 & 3 & 3 & 3 & 3 & 4 & 4 \\
\hline 4 & 4 & 3 & 3 & 3 & 3 & 1 & 2 & 2 \\
\hline 3 & 3 & 3 & 3 & 4 & 4 & 4 & 4 & 2 \\
\hline 3 & 3 & 3 & 3 & 4 & 4 & 4 & 4 & 4 \\
\hline 3 & 3 & 3 & 3 & 3 & 2 & 4 & 4 & 4 \\
\hline 3 & 2 & 4 & 4 & 4 & 4 & 3 & 3 & 4 \\
\hline 4 & 4 & 3 & 3 & 3 & 3 & 3 & 2 & 4 \\
\hline 4 & 4 & 4 & 3 & 3 & 3 & 4 & 4 & 4 \\
\hline 3 & 3 & 3 & 3 & 4 & 4 & 3 & 3 & 2 \\
\hline 3 & 3 & 3 & 4 & 4 & 3 & 3 & 3 & 2 \\
\hline 2 & 2 & 4 & 4 & 4 & 3 & 3 & 3 & 3 \\
\hline 3 & 3 & 3 & 4 & 4 & 4 & 4 & 4 & 3 \\
\hline 2 & 2 & 3 & 3 & 3 & 4 & 4 & 4 & 4 \\
\hline 3 & 3 & 3 & 2 & 4 & 4 & 4 & 4 & 4 \\
\hline 3 & 4 & 4 & 4 & 3 & 3 & 4 & 1 & 3 \\
\hline 4 & 4 & 4 & 4 & 3 & 3 & 3 & 1 & 4 \\
\hline 3 & 2 & 2 & 4 & 4 & 4 & 3 & 3 & 3 \\
\hline 3 & 3 & 3 & 3 & 3 & 4 & 4 & 4 & $\overline{4}$ \\
\hline 4 & 4 & 3 & 3 & 3 & 3 & 4 & 4 & 4 \\
\hline 4 & 4 & 3 & 3 & 3 & 3 & 3 & 3 & 4 \\
\hline 3 & 4 & 4 & 4 & 3 & 3 & 3 & 3 & 3 \\
\hline 2 & 2 & 3 & 3 & 1 & 3 & 3 & 4 & 4 \\
\hline 3 & 3 & 3 & 1 & 3 & 4 & 4 & 3 & 3 \\
\hline 2 & 3 & 3 & 4 & 4 & 4 & 4 & 2 & 2 \\
\hline 2 & 4 & 4 & 4 & 4 & 4 & 3 & 3 & 3 \\
\hline 3 & 3 & 3 & 1 & 3 & 2 & 4 & 4 & 4 \\
\hline 2 & 3 & 4 & 4 & 4 & 1 & 3 & 3 & 4 \\
\hline 4 & 4 & 4 & 4 & 3 & 3 & 3 & 3 & 3 \\
\hline 2 & 3 & 3 & 1 & 3 & 3 & 3 & 4 & 4 \\
\hline 3 & 3 & 3 & 3 & 3 & 3 & 3 & 3 & 4 \\
\hline 3 & 3 & 3 & 3 & 3 & 3 & 3 & 3 & 3 \\
\hline 4 & 4 & 4 & 4 & 2 & 4 & 4 & 4 & 3 \\
\hline 3 & 3 & 3 & 4 & 4 & 4 & 3 & 3 & 3 \\
\hline 3 & 3 & 3 & 3 & 4 & 4 & 4 & 4 & 4 \\
\hline 3 & 1 & 4 & 4 & 3 & 3 & 3 & 3 & 3 \\
\hline 3 & 3 & 3 & 4 & 4 & 4 & 4 & 4 & 3 \\
\hline 4 & 4 & 3 & 1 & 3 & 3 & 2 & 3 & 3 \\
\hline 3 & 3 & 3 & 3 & 4 & 4 & 2 & 2 & $\overline{4}$ \\
\hline
\end{tabular}


DATA PENELITIAN MOTIVASI KERJA AITEM

\begin{tabular}{|c|c|c|c|c|c|c|c|c|}
\hline 27 & 28 & 29 & 30 & 31 & 32 & 33 & 34 & 35 \\
\hline 4 & 3 & 3 & 4 & 3 & 4 & 1 & 3 & 3 \\
\hline 4 & 4 & 4 & 3 & 3 & 3 & 3 & 3 & 3 \\
\hline 4 & 4 & 4 & 4 & 4 & 4 & 1 & 3 & 3 \\
\hline 3 & 3 & 3 & 3 & 3 & 3 & 3 & 3 & 4 \\
\hline 4 & 4 & 4 & 4 & 4 & 3 & 2 & 3 & 3 \\
\hline 4 & 3 & 3 & 2 & 4 & 4 & 4 & 4 & 4 \\
\hline 4 & 4 & 4 & 4 & 4 & 4 & 4 & 2 & 3 \\
\hline 4 & 4 & 3 & 3 & 3 & 3 & 2 & 3 & 3 \\
\hline 2 & 3 & 3 & 3 & 3 & 3 & 3 & 4 & 4 \\
\hline 4 & 4 & 4 & 4 & 3 & 3 & 2 & 3 & 3 \\
\hline 4 & 4 & 4 & 4 & 4 & 3 & 3 & 3 & 4 \\
\hline 4 & 4 & 3 & 3 & 1 & 3 & 4 & 4 & 4 \\
\hline 3 & 4 & 4 & 4 & 4 & 3 & 3 & 3 & 2 \\
\hline 4 & 4 & 4 & 4 & 4 & 3 & 3 & 3 & 4 \\
\hline 4 & 4 & 4 & 3 & 3 & 2 & 3 & 3 & 4 \\
\hline 4 & 4 & 3 & 3 & 3 & 3 & 3 & 3 & 3 \\
\hline 4 & 4 & 4 & 4 & 3 & 3 & 2 & 2 & 3 \\
\hline 3 & 3 & 4 & 4 & 1 & 3 & 4 & 4 & 3 \\
\hline 3 & 3 & 4 & 4 & 4 & 3 & 3 & 1 & 3 \\
\hline 4 & 4 & 4 & 3 & 3 & 3 & 4 & 4 & 4 \\
\hline 4 & 3 & 3 & 4 & 3 & 3 & 3 & 3 & 3 \\
\hline 4 & 4 & 3 & 3 & 3 & 3 & 4 & 4 & 2 \\
\hline 2 & 3 & 4 & 4 & 4 & 3 & 3 & 3 & 4 \\
\hline 3 & 3 & 3 & 3 & 3 & 4 & 1 & 3 & 3 \\
\hline 3 & 3 & 3 & 3 & 4 & 4 & 3 & 3 & 3 \\
\hline 3 & 3 & 4 & 3 & 4 & 2 & 3 & 3 & 2 \\
\hline 4 & 4 & 3 & 3 & 4 & 3 & 1 & 3 & 2 \\
\hline 3 & 3 & 3 & 3 & 3 & 4 & 4 & 4 & 3 \\
\hline 4 & 4 & 4 & 4 & 3 & 3 & 3 & 3 & 3 \\
\hline 4 & 4 & 3 & 3 & 2 & 2 & 3 & 4 & 4 \\
\hline 3 & 3 & 4 & 4 & 4 & 3 & 3 & 4 & 4 \\
\hline 3 & 4 & 4 & 4 & 3 & 3 & 3 & 3 & 4 \\
\hline 3 & 3 & 3 & 4 & 4 & 2 & 3 & 3 & 2 \\
\hline 3 & 3 & 3 & 3 & 3 & 3 & 3 & 3 & 4 \\
\hline 4 & 4 & 3 & 3 & 3 & 3 & 4 & 4 & 4 \\
\hline 3 & 3 & 3 & 3 & 3 & 3 & 3 & 4 & 3 \\
\hline 4 & 3 & 3 & 4 & 4 & 4 & 3 & 3 & 3 \\
\hline 1 & 3 & 4 & 4 & 4 & 3 & 3 & 3 & 3 \\
\hline 3 & 1 & 3 & 4 & 4 & 3 & 3 & 3 & 3 \\
\hline 3 & 4 & 1 & 3 & 4 & 3 & 3 & 3 & 3 \\
\hline 3 & 3 & 3 & 3 & 2 & 2 & 4 & 4 & 3 \\
\hline 3 & 3 & 4 & 4 & 4 & 4 & 4 & 4 & 3 \\
\hline
\end{tabular}




\begin{tabular}{|c|c|c|c|c|c|c|c|c|}
\hline 3 & 3 & 4 & 4 & 4 & 4 & 3 & 3 & 4 \\
\hline 4 & 4 & 4 & 4 & 4 & 4 & 4 & 4 & 3 \\
\hline 3 & 3 & 4 & 4 & 4 & 4 & 4 & 4 & 4 \\
\hline 1 & 3 & 3 & 3 & 4 & 4 & 4 & 3 & 3 \\
\hline 4 & 3 & 3 & 3 & 4 & 4 & 3 & 3 & 3 \\
\hline 1 & 3 & 3 & 4 & 4 & 4 & 3 & 3 & 3 \\
\hline 4 & 2 & 3 & 3 & 3 & 3 & 2 & 3 & 3 \\
\hline 2 & 2 & 3 & 3 & 3 & 4 & 4 & 4 & 3 \\
\hline 4 & 4 & 3 & 3 & 3 & 3 & 3 & 3 & 4 \\
\hline 4 & 4 & 4 & 3 & 3 & 3 & 3 & 3 & 4 \\
\hline 4 & 3 & 3 & 2 & 3 & 3 & 3 & 3 & 3 \\
\hline 4 & 4 & 4 & 4 & 4 & 4 & 4 & 3 & 3 \\
\hline 4 & 3 & 3 & 3 & 3 & 3 & 3 & 3 & 3 \\
\hline 4 & 3 & 3 & 3 & 3 & 3 & 3 & 3 & 3 \\
\hline 1 & 3 & 3 & 3 & 3 & 3 & 3 & 3 & 3 \\
\hline 3 & 3 & 4 & 4 & 4 & 4 & 3 & 3 & 3 \\
\hline 3 & 3 & 4 & 4 & 4 & 2 & 4 & 4 & 4 \\
\hline 3 & 3 & 3 & 3 & 3 & 3 & 3 & 3 & 3 \\
\hline 3 & 3 & 3 & 3 & 3 & 4 & 4 & 2 & 3 \\
\hline 3 & 3 & 3 & 3 & 3 & 3 & 4 & 4 & 4 \\
\hline 3 & 3 & 3 & 3 & 4 & 4 & 4 & 4 & 4 \\
\hline 3 & 3 & 3 & 2 & 4 & 4 & 4 & 3 & 3 \\
\hline 3 & 3 & 3 & 4 & 4 & 4 & 3 & 3 & 3 \\
\hline 4 & 3 & 3 & 3 & 3 & 3 & 3 & 3 & 3 \\
\hline 1 & 4 & 3 & 3 & 3 & 3 & 3 & 3 & 4 \\
\hline 4 & 4 & 3 & 3 & 3 & 3 & 3 & 3 & 3 \\
\hline 1 & 3 & 4 & 4 & 4 & 3 & 3 & 3 & 3 \\
\hline 4 & 4 & 3 & 3 & 3 & 3 & 2 & 3 & 3 \\
\hline 3 & 3 & 3 & 4 & 4 & 4 & 4 & 3 & 3 \\
\hline 3 & 4 & 4 & 3 & 3 & 3 & 2 & 4 & 4 \\
\hline 3 & 3 & 2 & 3 & 3 & 3 & 3 & 3 & 3 \\
\hline 4 & 3 & 3 & 3 & 3 & 3 & 3 & 3 & 3 \\
\hline 4 & 3 & 3 & 3 & 3 & 4 & 4 & 4 & 4 \\
\hline 3 & 3 & 3 & 3 & 4 & 4 & 4 & 3 & 3 \\
\hline 4 & 4 & 3 & 3 & 3 & 3 & 3 & 2 & 3 \\
\hline 4 & 4 & 4 & 4 & 4 & 4 & 4 & 3 & 3 \\
\hline 2 & 2 & 4 & 4 & 3 & 3 & 3 & 3 & 3 \\
\hline 3 & 3 & 3 & 3 & 3 & 3 & 4 & 4 & 4 \\
\hline 2 & 3 & 3 & 3 & 3 & 3 & 1 & 4 & 4 \\
\hline 4 & 4 & 4 & 2 & 2 & 4 & 3 & 3 & 3 \\
\hline 3 & 3 & 3 & 3 & 3 & 3 & 3 & 3 & 3 \\
\hline 3 & 3 & 3 & 3 & 3 & 3 & 4 & 4 & 2 \\
\hline 3 & 4 & 4 & 4 & 4 & 4 & 4 & 4 & 3 \\
\hline 4 & 3 & 3 & 3 & 3 & 3 & 3 & 3 & $\overline{4}$ \\
\hline
\end{tabular}


MOTIVASI KERJAAITEM

\begin{tabular}{|c|c|c|c|c|c|c|c|c|}
\hline 36 & 37 & 38 & 39 & 40 & 41 & 42 & 43 & 44 \\
\hline 4 & 3 & 4 & 3 & 1 & 4 & 3 & 3 & 3 \\
\hline 3 & 3 & 4 & 4 & 2 & 3 & 3 & 3 & 3 \\
\hline 3 & 3 & 3 & 3 & 2 & 3 & 4 & 4 & 4 \\
\hline 4 & 4 & 4 & 4 & 4 & 4 & 2 & 3 & 3 \\
\hline 3 & 3 & 3 & 3 & 3 & 4 & 2 & 2 & 3 \\
\hline 4 & 4 & 4 & 4 & 3 & 3 & 3 & 3 & 4 \\
\hline 3 & 3 & 3 & 3 & 3 & 3 & 2 & 3 & 3 \\
\hline 3 & 4 & 4 & 3 & 2 & 3 & 3 & 3 & 4 \\
\hline 4 & 4 & 4 & 3 & 3 & 3 & 3 & 3 & 3 \\
\hline 3 & 3 & 3 & 4 & 4 & 4 & 3 & 4 & 3 \\
\hline 4 & 4 & 3 & 3 & 4 & 4 & 4 & 3 & 3 \\
\hline 3 & 3 & 3 & 3 & 3 & 4 & 4 & 4 & 3 \\
\hline 3 & 4 & 4 & 4 & 3 & 1 & 3 & 3 & 4 \\
\hline 3 & 3 & 3 & 4 & 3 & 3 & 3 & 3 & 3 \\
\hline 4 & 1 & 3 & 3 & 3 & 4 & 4 & 3 & 3 \\
\hline 3 & 3 & 3 & 2 & 4 & 3 & 3 & 3 & 3 \\
\hline 3 & 3 & 4 & 4 & 4 & 4 & 4 & 3 & 3 \\
\hline 3 & 3 & 3 & 4 & 4 & 2 & 4 & 4 & 4 \\
\hline 3 & 3 & 4 & 4 & 4 & 4 & 2 & 3 & 3 \\
\hline 3 & 3 & 3 & 3 & 3 & 3 & 4 & 4 & 2 \\
\hline 3 & 1 & 3 & 3 & 3 & 4 & 4 & 3 & 4 \\
\hline 3 & 3 & 2 & 2 & 3 & 3 & 4 & 4 & 4 \\
\hline 4 & 4 & 3 & 3 & 3 & 4 & 4 & 3 & 3 \\
\hline 4 & 4 & 4 & 3 & 3 & 3 & 3 & 3 & 3 \\
\hline 3 & 3 & 3 & 3 & 3 & 3 & 3 & 3 & 4 \\
\hline 3 & 4 & 4 & 3 & 3 & 4 & 4 & 4 & 3 \\
\hline 4 & 4 & 3 & 3 & 3 & 4 & 4 & 4 & 3 \\
\hline 3 & 3 & 4 & 4 & 4 & 3 & 3 & 3 & 3 \\
\hline 3 & 3 & 3 & 3 & 3 & 3 & 3 & 3 & 3 \\
\hline 4 & 4 & 4 & 4 & 3 & 3 & 3 & 1 & 3 \\
\hline 4 & 4 & 4 & 3 & 3 & 3 & 4 & 4 & 4 \\
\hline 4 & 4 & 3 & 3 & 3 & 3 & 4 & 4 & 4 \\
\hline 2 & 3 & 4 & 4 & 4 & 4 & 3 & 3 & 3 \\
\hline 4 & 2 & 3 & 3 & 3 & 3 & 3 & 3 & 4 \\
\hline 4 & 3 & 3 & 3 & 3 & 3 & 3 & 3 & 3 \\
\hline 3 & 3 & 4 & 4 & 4 & 3 & 3 & 3 & 2 \\
\hline 3 & 4 & 4 & 4 & 4 & 4 & 4 & 4 & 4 \\
\hline 3 & 4 & 4 & 4 & 4 & 2 & 3 & 3 & 4 \\
\hline 3 & 4 & 4 & 4 & 4 & 4 & 4 & 3 & 3 \\
\hline 3 & 3 & 4 & 4 & 4 & 2 & 3 & 4 & 4 \\
\hline 3 & 3 & 4 & 4 & 1 & 3 & 3 & 2 & 2 \\
\hline 3 & 3 & 3 & 3 & 3 & 3 & 1 & 3 & 2 \\
\hline
\end{tabular}




\begin{tabular}{|c|c|c|c|c|c|c|c|c|}
\hline 4 & 4 & 3 & 3 & 3 & 4 & 4 & 3 & 3 \\
\hline 3 & 3 & 3 & 3 & 3 & 3 & 4 & 4 & 4 \\
\hline 4 & 4 & 4 & 3 & 3 & 3 & 3 & 3 & 3 \\
\hline 3 & 3 & 4 & 4 & 4 & 3 & 3 & 3 & 3 \\
\hline 3 & 3 & 4 & 4 & 4 & 4 & 4 & 4 & 3 \\
\hline 3 & 3 & 3 & 3 & 3 & 3 & 3 & 4 & 4 \\
\hline 3 & 4 & 4 & 4 & 4 & 4 & 4 & 4 & 4 \\
\hline 3 & 3 & 3 & 3 & 3 & 3 & 3 & 3 & 4 \\
\hline 4 & 4 & 4 & 3 & 3 & 3 & 3 & 3 & 3 \\
\hline 4 & 4 & 4 & 4 & 4 & 2 & 3 & 3 & 3 \\
\hline 3 & 3 & 4 & 4 & 4 & 3 & 3 & 3 & 3 \\
\hline 3 & 4 & 4 & 4 & 4 & 4 & 4 & 4 & 4 \\
\hline 3 & 3 & 3 & 2 & 3 & 3 & 3 & 3 & 3 \\
\hline 3 & 3 & 2 & 2 & 2 & 3 & 3 & 3 & 4 \\
\hline 4 & 3 & 3 & 2 & 3 & 3 & 3 & 3 & 4 \\
\hline 3 & 3 & 3 & 3 & 2 & 4 & 2 & 3 & 3 \\
\hline 3 & 3 & 3 & 3 & 3 & 3 & 4 & 4 & 4 \\
\hline 3 & 3 & 2 & 3 & 3 & 4 & 4 & 3 & 3 \\
\hline 3 & 3 & 3 & 3 & 4 & 4 & 4 & 2 & 3 \\
\hline 4 & 4 & 4 & 4 & 4 & 4 & 3 & 3 & 3 \\
\hline 2 & 3 & 3 & 3 & 4 & 4 & 4 & 4 & 4 \\
\hline 3 & 3 & 3 & 4 & 4 & 4 & 4 & 4 & 4 \\
\hline 3 & 3 & 2 & 4 & 4 & 3 & 3 & 3 & 3 \\
\hline 3 & 3 & 3 & 2 & 3 & 3 & 3 & 3 & 3 \\
\hline 4 & 4 & 4 & 4 & 3 & 3 & 3 & 3 & 3 \\
\hline 3 & 3 & 3 & 3 & 3 & 3 & 2 & 2 & 3 \\
\hline 3 & 3 & 4 & 4 & 4 & 4 & 3 & 3 & 3 \\
\hline 3 & 4 & 4 & 4 & 4 & 3 & 3 & 3 & 3 \\
\hline 3 & 4 & 4 & 4 & 3 & 3 & 3 & 3 & 1 \\
\hline 4 & 4 & 4 & 3 & 3 & 3 & 3 & 3 & 3 \\
\hline 4 & 4 & 2 & 3 & 3 & 3 & 3 & 4 & 4 \\
\hline 3 & 2 & 2 & 3 & 3 & 4 & 4 & 4 & 3 \\
\hline 4 & 3 & 3 & 3 & 3 & 3 & 4 & 1 & 3 \\
\hline 3 & 3 & 3 & 3 & 4 & 4 & 4 & 4 & 3 \\
\hline 3 & 3 & 3 & 3 & 3 & 4 & 4 & 4 & 3 \\
\hline 3 & 3 & 4 & 4 & 2 & 3 & 4 & 1 & 3 \\
\hline 4 & 4 & 3 & 3 & 1 & 3 & 3 & 3 & 2 \\
\hline 4 & 4 & 4 & 2 & 3 & 3 & 3 & 1 & 3 \\
\hline 3 & 3 & 3 & 3 & 3 & 3 & 3 & 3 & 3 \\
\hline 3 & 3 & 3 & 3 & 4 & 4 & 4 & 4 & 3 \\
\hline 3 & 4 & 4 & 3 & 3 & 3 & 3 & 3 & 3 \\
\hline 2 & 3 & 3 & 3 & 3 & 3 & 3 & 3 & 3 \\
\hline 3 & 3 & 3 & 3 & 3 & 3 & 3 & 3 & 3 \\
\hline 4 & 4 & 4 & 4 & 4 & 4 & 3 & 1 & 3 \\
\hline
\end{tabular}




\begin{tabular}{|c|c|c|c|c|c|c|c|c|}
\hline 45 & 46 & 47 & 48 & 49 & 50 & 51 & 52 & 53 \\
\hline 4 & 4 & 3 & 4 & 4 & 4 & 4 & 3 & 3 \\
\hline 3 & 3 & 3 & 3 & 3 & 3 & 3 & 3 & 4 \\
\hline 4 & 4 & 4 & 4 & 4 & 4 & 3 & 3 & 3 \\
\hline 3 & 4 & 4 & 3 & 3 & 3 & 3 & 3 & 3 \\
\hline 3 & 3 & 3 & 3 & 3 & 3 & 3 & 4 & 4 \\
\hline 4 & 4 & 4 & 4 & 4 & 4 & 3 & 3 & 3 \\
\hline 4 & 4 & 4 & 4 & 4 & 4 & 4 & 4 & 4 \\
\hline 4 & 4 & 3 & 3 & 3 & 3 & 3 & 3 & 4 \\
\hline 3 & 2 & 3 & 3 & 3 & 3 & 3 & 3 & 3 \\
\hline 3 & 3 & 4 & 4 & 4 & 4 & 4 & 4 & 4 \\
\hline 2 & 3 & 3 & 3 & 4 & 3 & 3 & 3 & 3 \\
\hline 3 & 3 & 2 & 3 & 3 & 3 & 4 & 4 & 4 \\
\hline 4 & 3 & 3 & 3 & 3 & 4 & 4 & 4 & 4 \\
\hline 2 & 3 & 3 & 3 & 3 & 3 & 4 & 3 & 3 \\
\hline 3 & 3 & 4 & 4 & 4 & 4 & 4 & 4 & 3 \\
\hline 4 & 4 & 4 & 4 & 4 & 3 & 3 & 3 & 3 \\
\hline 3 & 3 & 3 & 4 & 4 & 4 & 3 & 3 & 3 \\
\hline 4 & 3 & 3 & 3 & 3 & 3 & 3 & 3 & 3 \\
\hline 3 & 3 & 3 & 4 & 4 & 4 & 3 & 3 & 3 \\
\hline 2 & 4 & 4 & 3 & 3 & 3 & 3 & 3 & 3 \\
\hline 4 & 3 & 3 & 3 & 3 & 2 & 3 & 4 & 4 \\
\hline 3 & 3 & 4 & 4 & 4 & 3 & 3 & 3 & 3 \\
\hline 3 & 4 & 4 & 4 & 4 & 3 & 3 & 2 & 2 \\
\hline 4 & 4 & 3 & 3 & 3 & 3 & 3 & 4 & 4 \\
\hline 4 & 4 & 2 & 2 & 4 & 4 & 4 & 3 & 3 \\
\hline 3 & 3 & 3 & 3 & 4 & 4 & 4 & 4 & 4 \\
\hline 3 & 3 & 3 & 3 & 3 & 3 & 4 & 4 & 4 \\
\hline 3 & 3 & 3 & 3 & 3 & 3 & 3 & 3 & 3 \\
\hline 3 & 3 & 3 & 3 & 3 & 3 & 3 & 4 & 4 \\
\hline 4 & 4 & 3 & 3 & 3 & 4 & 4 & 3 & 3 \\
\hline 3 & 3 & 3 & 3 & 3 & 3 & 3 & 2 & 3 \\
\hline 2 & 4 & 4 & 3 & 3 & 4 & 4 & 3 & 3 \\
\hline 3 & 4 & 4 & 3 & 4 & 4 & 3 & 3 & 3 \\
\hline 4 & 4 & 4 & 4 & 3 & 3 & 3 & 3 & 3 \\
\hline 4 & 4 & 4 & 2 & 3 & 3 & 3 & 4 & 4 \\
\hline 2 & 3 & 3 & 3 & 4 & 4 & 4 & 4 & 4 \\
\hline 4 & 3 & 3 & 3 & 3 & 3 & 2 & 3 & 3 \\
\hline 4 & 4 & 4 & 3 & 3 & 3 & 4 & 4 & 4 \\
\hline 3 & 3 & 3 & 3 & 3 & 3 & 3 & 3 & 3 \\
\hline 4 & 3 & 3 & 3 & 3 & 3 & 3 & 3 & 4 \\
\hline 3 & 3 & 3 & 4 & 4 & 4 & 4 & 4 & 4 \\
\hline 3 & 3 & 3 & 2 & 2 & 3 & 4 & 4 & 4 \\
\hline
\end{tabular}




\begin{tabular}{|c|c|c|c|c|c|c|c|c|}
\hline 1 & 3 & 4 & 4 & 3 & 3 & 3 & 3 & 3 \\
\hline 4 & 4 & 4 & 4 & 4 & 4 & 4 & 4 & 4 \\
\hline 3 & 4 & 4 & 4 & 4 & 4 & 3 & 3 & 3 \\
\hline 3 & 3 & 3 & 2 & 4 & 3 & 3 & 3 & 3 \\
\hline 3 & 1 & 3 & 3 & 4 & 4 & 3 & 3 & 3 \\
\hline 4 & 4 & 2 & 4 & 4 & 3 & 3 & 3 & 3 \\
\hline 3 & 3 & 3 & 3 & 3 & 1 & 3 & 3 & 3 \\
\hline 4 & 4 & 4 & 3 & 3 & 3 & 3 & 3 & 3 \\
\hline 3 & 3 & 3 & 3 & 3 & 2 & 3 & 3 & 3 \\
\hline 3 & 1 & 3 & 3 & 4 & 4 & 4 & 4 & 4 \\
\hline 3 & 3 & 3 & 2 & 4 & 4 & 4 & 3 & 3 \\
\hline 3 & 3 & 3 & 3 & 3 & 2 & 3 & 3 & 3 \\
\hline 1 & 3 & 3 & 3 & 3 & 3 & 4 & 4 & 4 \\
\hline 4 & 4 & 3 & 3 & 3 & 3 & 3 & 3 & 3 \\
\hline 4 & 4 & 4 & 3 & 3 & 3 & 2 & 2 & 3 \\
\hline 3 & 3 & 3 & 3 & 3 & 4 & 4 & 3 & 3 \\
\hline 4 & 4 & 2 & 2 & 4 & 3 & 3 & 3 & 4 \\
\hline 2 & 4 & 4 & 4 & 3 & 3 & 3 & 3 & 3 \\
\hline 3 & 3 & 3 & 4 & 4 & 4 & 4 & 2 & 3 \\
\hline 3 & 3 & 3 & 2 & 2 & 1 & 3 & 3 & 3 \\
\hline 4 & 3 & 3 & 3 & 3 & 3 & 4 & 4 & 4 \\
\hline 4 & 3 & 1 & 3 & 3 & 3 & 4 & 4 & 4 \\
\hline 4 & 4 & 4 & 4 & 3 & 3 & 3 & 3 & 2 \\
\hline 3 & 3 & 3 & 3 & 1 & 3 & 3 & 3 & 3 \\
\hline 3 & 3 & 3 & 3 & 3 & 3 & 3 & 3 & 3 \\
\hline 4 & 4 & 1 & 3 & 3 & 3 & 4 & 4 & 4 \\
\hline 3 & 3 & 3 & 3 & 2 & 2 & 3 & 4 & 4 \\
\hline 3 & 3 & 3 & 3 & 3 & 3 & 3 & 4 & 4 \\
\hline 3 & 3 & 2 & 3 & 3 & 3 & 3 & 3 & 3 \\
\hline 3 & 3 & 2 & 4 & 4 & 4 & 3 & 3 & 3 \\
\hline 4 & 4 & 1 & 3 & 3 & 3 & 4 & 4 & 4 \\
\hline 3 & 3 & 3 & 3 & 3 & 4 & 4 & 4 & 4 \\
\hline 3 & 3 & 2 & 2 & 3 & 4 & 4 & 4 & 4 \\
\hline 3 & 3 & 3 & 3 & 4 & 4 & 2 & 2 & 3 \\
\hline 3 & 3 & 3 & 3 & 3 & 3 & 2 & 3 & 3 \\
\hline 4 & 4 & 4 & 3 & 3 & 3 & 2 & 2 & 4 \\
\hline 4 & 4 & 3 & 3 & 3 & 3 & 3 & 3 & 3 \\
\hline 3 & 3 & 4 & 4 & 4 & 3 & 3 & 3 & 3 \\
\hline 4 & 4 & 3 & 3 & 3 & 4 & 4 & 4 & 3 \\
\hline 2 & 2 & 4 & 4 & 4 & 3 & 3 & 1 & 3 \\
\hline 3 & 2 & 3 & 3 & 3 & 4 & 4 & 4 & 4 \\
\hline 3 & 3 & 3 & 3 & 3 & 3 & 3 & 3 & 3 \\
\hline 3 & 4 & 4 & 4 & 2 & 2 & 3 & 3 & 3 \\
\hline 3 & 3 & 3 & 2 & 4 & 4 & 3 & 3 & 3 \\
\hline
\end{tabular}




\begin{tabular}{|c|c|c|c|c|c|c|c|c|}
\hline 54 & 55 & 56 & 57 & 58 & 59 & 60 & 61 & 62 \\
\hline 4 & 4 & 3 & 3 & 4 & 4 & 4 & 4 & 3 \\
\hline 4 & 4 & 4 & 4 & 4 & 4 & 4 & 4 & 4 \\
\hline 3 & 3 & 3 & 3 & 3 & 3 & 3 & 3 & 3 \\
\hline 3 & 4 & 4 & 4 & 4 & 4 & 4 & 4 & 4 \\
\hline 4 & 4 & 4 & 4 & 4 & 4 & 4 & 4 & 4 \\
\hline 3 & 3 & 3 & 3 & 3 & 3 & 3 & 3 & 3 \\
\hline 4 & 4 & 4 & 4 & 4 & 4 & 4 & 4 & 4 \\
\hline 4 & 4 & 4 & 3 & 3 & 3 & 3 & 3 & 3 \\
\hline 3 & 3 & 3 & 4 & 4 & 4 & 3 & 4 & 4 \\
\hline 3 & 3 & 3 & 3 & 3 & 3 & 3 & 4 & 4 \\
\hline 3 & 3 & 4 & 4 & 4 & 4 & 4 & 4 & 4 \\
\hline 4 & 4 & 4 & 4 & 4 & 4 & 4 & 4 & 3 \\
\hline 3 & 3 & 3 & 3 & 3 & 3 & 3 & 4 & 4 \\
\hline 4 & 4 & 4 & 4 & 3 & 3 & 4 & 4 & 4 \\
\hline 3 & 3 & 3 & 4 & 4 & 4 & 3 & 2 & 2 \\
\hline 4 & 4 & 4 & 3 & 3 & 4 & 4 & 3 & 4 \\
\hline 3 & 3 & 2 & 4 & 4 & 4 & 4 & 3 & 3 \\
\hline 3 & 3 & 4 & 4 & 1 & 3 & 3 & 4 & 4 \\
\hline 3 & 4 & 4 & 4 & 4 & 4 & 4 & 4 & 3 \\
\hline 3 & 3 & 3 & 3 & 3 & 3 & 3 & 3 & 3 \\
\hline 4 & 3 & 3 & 3 & 3 & 4 & 4 & 4 & 4 \\
\hline 4 & 4 & 4 & 3 & 3 & 3 & 3 & 3 & 3 \\
\hline 4 & 4 & 4 & 3 & 3 & 3 & 3 & 2 & 3 \\
\hline 4 & 4 & 3 & 3 & 3 & 3 & 2 & 3 & 4 \\
\hline 3 & 3 & 3 & 4 & 4 & 4 & 4 & 4 & 4 \\
\hline 4 & 3 & 3 & 3 & 4 & 4 & 4 & 4 & 3 \\
\hline 3 & 4 & 4 & 4 & 3 & 3 & 3 & 4 & 4 \\
\hline 3 & 3 & 3 & 3 & 3 & 3 & 3 & 3 & 3 \\
\hline 4 & 4 & 4 & 4 & 2 & 3 & 4 & 4 & 4 \\
\hline 4 & 2 & 2 & 3 & 3 & 3 & 3 & 4 & 4 \\
\hline 3 & 3 & 3 & 4 & 3 & 3 & 3 & 3 & 3 \\
\hline 3 & 3 & 3 & 4 & 4 & 4 & 4 & 4 & 4 \\
\hline 3 & 4 & 4 & 3 & 3 & 3 & 4 & 4 & 4 \\
\hline 3 & 3 & 1 & 3 & 3 & 3 & 4 & 4 & 3 \\
\hline 4 & 3 & 3 & 3 & 4 & 4 & 4 & 4 & 4 \\
\hline 3 & 3 & 3 & 3 & 3 & 3 & 3 & 3 & 3 \\
\hline 4 & 4 & 3 & 3 & 4 & 4 & 3 & 3 & 3 \\
\hline 3 & 3 & 3 & 4 & 4 & 4 & 3 & 2 & 3 \\
\hline 3 & 3 & 3 & 3 & 3 & 3 & 3 & 3 & 3 \\
\hline 4 & 4 & 4 & 4 & 3 & 3 & 3 & 3 & 3 \\
\hline 3 & 3 & 3 & 3 & 3 & 4 & 4 & 4 & 4 \\
\hline 3 & 3 & 3 & 3 & 3 & 3 & 4 & 4 & 4 \\
\hline
\end{tabular}




\begin{tabular}{|c|c|c|c|c|c|c|c|c|}
\hline 3 & 3 & 3 & 3 & 3 & 3 & 3 & 3 & 3 \\
\hline 4 & 4 & 4 & 4 & 4 & 4 & 4 & 3 & 3 \\
\hline 3 & 3 & 3 & 4 & 4 & 4 & 3 & 3 & 2 \\
\hline 4 & 4 & 4 & 4 & 4 & 4 & 4 & 4 & 4 \\
\hline 3 & 3 & 3 & 3 & 3 & 4 & 4 & 4 & 4 \\
\hline 4 & 4 & 4 & 4 & 3 & 3 & 3 & 3 & 3 \\
\hline 4 & 4 & 4 & 4 & 4 & 4 & 3 & 3 & 3 \\
\hline 3 & 2 & 2 & 3 & 4 & 3 & 3 & 3 & 3 \\
\hline 1 & 3 & 3 & 3 & 4 & 4 & 4 & 3 & 3 \\
\hline 4 & 3 & 3 & 3 & 3 & 3 & 4 & 4 & 4 \\
\hline 3 & 3 & 3 & 3 & 3 & 3 & 3 & 3 & 3 \\
\hline 3 & 3 & 3 & 3 & 3 & 4 & 4 & 4 & 4 \\
\hline 4 & 4 & 4 & 4 & 4 & 3 & 3 & 3 & 3 \\
\hline 3 & 3 & 3 & 3 & 3 & 3 & 3 & 3 & 3 \\
\hline 3 & 3 & 3 & 4 & 4 & 4 & 3 & 3 & 3 \\
\hline 3 & 3 & 3 & 4 & 3 & 1 & 3 & 3 & 4 \\
\hline 4 & 4 & 4 & 4 & 4 & 3 & 3 & 3 & 3 \\
\hline 3 & 3 & 3 & 3 & 3 & 2 & 3 & 4 & 4 \\
\hline 3 & 3 & 3 & 3 & 3 & 3 & 3 & 3 & 3 \\
\hline 3 & 3 & 2 & 3 & 3 & 4 & 4 & 4 & 4 \\
\hline 2 & 2 & 4 & 3 & 3 & 3 & 3 & 3 & 4 \\
\hline 3 & 3 & 3 & 3 & 3 & 3 & 3 & 3 & 3 \\
\hline 3 & 3 & 3 & 3 & 3 & 3 & 3 & 4 & 4 \\
\hline 3 & 4 & 4 & 4 & 4 & 4 & 3 & 3 & 3 \\
\hline 1 & 3 & 3 & 4 & 4 & 4 & 4 & 3 & 3 \\
\hline 4 & 4 & 4 & 3 & 3 & 3 & 3 & 3 & 3 \\
\hline 4 & 3 & 3 & 3 & 3 & 3 & 4 & 4 & 4 \\
\hline 4 & 4 & 4 & 3 & 3 & 3 & 3 & 3 & 3 \\
\hline 4 & 4 & 4 & 3 & 3 & 3 & 3 & 2 & 2 \\
\hline 3 & 3 & 3 & 1 & 2 & 3 & 3 & 3 & 4 \\
\hline 3 & 3 & 4 & 4 & 2 & 2 & 4 & 4 & 4 \\
\hline 4 & 3 & 3 & 3 & 3 & 1 & 3 & 3 & 3 \\
\hline 3 & 3 & 2 & 3 & 4 & 4 & 4 & 3 & 3 \\
\hline 3 & 4 & 4 & 3 & 3 & 3 & 3 & 3 & 3 \\
\hline 3 & 3 & 3 & 3 & 4 & 4 & 4 & 3 & 3 \\
\hline 4 & 3 & 3 & 3 & 3 & 4 & 4 & 4 & 4 \\
\hline 3 & 2 & 3 & 3 & 3 & 3 & 3 & 3 & 4 \\
\hline 3 & 3 & 3 & 3 & 4 & 4 & 4 & 4 & 4 \\
\hline 3 & 3 & 4 & 4 & 4 & 1 & 4 & 4 & 3 \\
\hline 3 & 3 & 3 & 3 & 3 & 3 & 2 & 2 & 2 \\
\hline 2 & 3 & 2 & 1 & 3 & 3 & 3 & 3 & 4 \\
\hline 3 & 3 & 3 & 3 & 3 & 3 & 4 & 4 & 2 \\
\hline 3 & 3 & 2 & 4 & 4 & 4 & 4 & 4 & 4 \\
\hline 3 & 4 & 4 & 4 & 3 & 3 & 3 & 2 & \\
\hline
\end{tabular}




\begin{tabular}{|c|c|c|c|c|c|c|c|c|c|c|}
\hline & & & & & & & & & & TOTAL \\
\hline 63 & 64 & & & 66 & & 67 & & 68 & 69 & 70 \\
\hline 3 & 3 & 4 & 3 & & 3 & & 3 & \begin{tabular}{l|l} 
& 4
\end{tabular} & 3 & 228 \\
\hline 4 & 4 & 4 & 4 & & 4 & & 4 & 4 & 4 & 238 \\
\hline 3 & 3 & 3 & 3 & & 3 & & 3 & 3 & 3 & 229 \\
\hline 4 & 4 & 3 & 3 & & 2 & & 2 & 4 & 4 & 237 \\
\hline 4 & 4 & 4 & 4 & & 4 & & 4 & 4 & 4 & 238 \\
\hline 3 & 3 & 3 & 3 & & 4 & & 4 & 4 & 4 & 235 \\
\hline 3 & 3 & 3 & 2 & & 3 & & 3 & 4 & 4 & 249 \\
\hline 3 & 3 & 3 & 3 & & 3 & & 3 & 3 & 3 & 227 \\
\hline 4 & 3 & 3 & 3 & & 3 & & 3 & 3 & 3 & 228 \\
\hline 2 & 3 & 3 & 3 & & 3 & & 3 & 3 & 4 & 232 \\
\hline 4 & 4 & 4 & 4 & & 4 & & 4 & 4 & 4 & 240 \\
\hline 3 & 3 & 3 & 3 & & 3 & & 3 & 3 & 3 & 233 \\
\hline 4 & 4 & 3 & 4 & & 3 & & 3 & 3 & 3 & 230 \\
\hline 4 & 4 & 3 & 3 & & 3 & & 3 & 3 & 4 & 236 \\
\hline 4 & 4 & 4 & 4 & & 3 & & 3 & 3 & 3 & 229 \\
\hline 4 & 4 & 4 & 4 & & 4 & & 4 & 3 & 3 & 236 \\
\hline 3 & 4 & 4 & 4 & & 1 & & 3 & 3 & 3 & 229 \\
\hline 4 & 3 & 3 & 3 & & 3 & & 3 & 3 & 3 & 225 \\
\hline 3 & 3 & 3 & 3 & & 3 & & 3 & 3 & 4 & 233 \\
\hline 3 & 4 & 4 & 3 & & 4 & & 4 & 3 & 3 & 223 \\
\hline 4 & 4 & 3 & 3 & & 3 & & 3 & 3 & 3 & 224 \\
\hline 3 & 3 & 3 & 2 & & 3 & & 3 & 4 & 4 & 224 \\
\hline 3 & 4 & 4 & 3 & & 3 & & 3 & 4 & 4 & 231 \\
\hline 4 & 4 & 4 & 4 & & 4 & & 3 & 3 & 3 & 232 \\
\hline 4 & 4 & 4 & 4 & & 4 & & 3 & 3 & 3 & 236 \\
\hline 3 & 3 & 2 & 4 & & 3 & & 3 & 4 & 4 & 230 \\
\hline 4 & 1 & 3 & 3 & & 3 & & 4 & 4 & 4 & 234 \\
\hline 3 & 3 & 3 & 3 & & 3 & & 3 & 3 & 3 & 221 \\
\hline 4 & 4 & 3 & 3 & & 3 & & 3 & 3 & 3 & 227 \\
\hline 4 & 3 & 3 & 4 & & 4 & & 3 & 3 & 3 & 222 \\
\hline 3 & 3 & 3 & 3 & & 3 & & 3 & 3 & 3 & 226 \\
\hline 3 & 3 & 3 & 3 & & 4 & & 4 & 3 & 3 & 231 \\
\hline 4 & 3 & 3 & 3 & & 2 & & 3 & 3 & 4 & 229 \\
\hline 3 & 3 & 3 & 4 & & 4 & & 4 & 4 & 3 & 231 \\
\hline 4 & 3 & 3 & 3 & & 3 & & 3 & 4 & 4 & 229 \\
\hline 3 & 3 & 3 & 3 & & 3 & & 3 & 3 & 3 & 222 \\
\hline 3 & 3 & 4 & 4 & & 4 & & 3 & 3 & 3 & 236 \\
\hline 3 & 4 & 4 & 4 & & 3 & & 3 & 3 & 3 & 224 \\
\hline 3 & 3 & 3 & 3 & & 3 & & 3 & 3 & 3 & 217 \\
\hline 2 & 4 & 4 & 3 & & 3 & & 3 & 3 & 3 & 229 \\
\hline 3 & 3 & 3 & 3 & & 3 & & 3 & 3 & 3 & 226 \\
\hline 4 & 4 & 4 & 4 & & 3 & & 3 & 3 & 3 & 228 \\
\hline
\end{tabular}




\begin{tabular}{|c|c|c|c|c|c|c|c|c|}
\hline 3 & 3 & 3 & 3 & 3 & 3 & 3 & 3 & 224 \\
\hline 3 & 3 & 3 & 3 & 4 & 4 & 4 & 4 & 257 \\
\hline 3 & 3 & 3 & 3 & 3 & 3 & 3 & 3 & 233 \\
\hline 4 & 4 & 4 & 4 & 4 & 4 & 4 & 4 & 237 \\
\hline 4 & 4 & 3 & 3 & 3 & 3 & 3 & 3 & 230 \\
\hline 3 & 3 & 3 & 3 & 3 & 3 & 3 & 3 & 224 \\
\hline 3 & 3 & 3 & 3 & 3 & 3 & 3 & 3 & 224 \\
\hline 3 & 3 & 3 & 3 & 4 & 4 & 4 & 4 & 233 \\
\hline 3 & 3 & 3 & 3 & 4 & 4 & 4 & 4 & 223 \\
\hline 3 & 3 & 2 & 2 & 3 & 3 & 3 & 3 & 230 \\
\hline 3 & 3 & 3 & 3 & 3 & 3 & 1 & 3 & 219 \\
\hline 4 & 4 & 4 & 3 & 3 & 2 & 2 & 3 & 236 \\
\hline 3 & 3 & 3 & 3 & 3 & 3 & 3 & 3 & 220 \\
\hline 3 & 3 & 3 & 3 & 2 & 2 & 3 & 3 & 217 \\
\hline 3 & 4 & 4 & 4 & 3 & 3 & 3 & 3 & 219 \\
\hline 4 & 3 & 3 & 3 & 2 & 2 & 4 & 4 & 219 \\
\hline 3 & 3 & 3 & 3 & 3 & 3 & 3 & 3 & 230 \\
\hline 3 & 3 & 3 & 3 & 3 & 2 & 4 & 4 & 218 \\
\hline 4 & 4 & 4 & 4 & 4 & 3 & 3 & 3 & 226 \\
\hline 3 & 3 & 3 & 3 & 2 & 3 & 3 & 3 & 222 \\
\hline 4 & 4 & 4 & 4 & 3 & 3 & 3 & 3 & 230 \\
\hline 3 & 3 & 3 & 3 & 3 & 3 & 3 & 3 & 230 \\
\hline 4 & 3 & 3 & 3 & 3 & 3 & 3 & 3 & 225 \\
\hline 3 & 3 & 3 & 3 & 3 & 3 & 4 & 4 & 221 \\
\hline 3 & 2 & 2 & 3 & 3 & 3 & 3 & 3 & 221 \\
\hline 2 & 2 & 3 & 3 & 3 & 3 & 4 & 4 & 223 \\
\hline 3 & 4 & 4 & 3 & 2 & 3 & 3 & 4 & 227 \\
\hline 3 & 3 & 4 & 1 & 3 & 4 & 2 & 3 & 220 \\
\hline 2 & 3 & 3 & 4 & 4 & 4 & 3 & 3 & 219 \\
\hline 4 & 4 & 3 & 3 & 3 & 3 & 3 & 3 & 219 \\
\hline 3 & 3 & 3 & 3 & 4 & 2 & 4 & 4 & 224 \\
\hline 3 & 3 & 3 & 2 & 2 & 4 & 3 & 3 & 216 \\
\hline 3 & 2 & 2 & 3 & 3 & 1 & 4 & 4 & 221 \\
\hline 4 & 4 & 1 & 3 & 3 & 4 & 4 & 3 & 223 \\
\hline 3 & 3 & 3 & 4 & 2 & 2 & 4 & 4 & 220 \\
\hline 3 & 4 & 3 & 2 & 4 & 4 & 3 & 3 & 228 \\
\hline 4 & 3 & 3 & 3 & 3 & 3 & 2 & 3 & 209 \\
\hline 4 & 2 & 4 & 4 & 3 & 2 & 2 & 3 & 227 \\
\hline 3 & 3 & 3 & 3 & 2 & 2 & 4 & 4 & 228 \\
\hline 4 & 4 & 4 & 3 & 3 & 3 & 3 & 3 & 221 \\
\hline 4 & 4 & 2 & 2 & 3 & 1 & 4 & 4 & 213 \\
\hline 2 & 4 & 1 & 3 & 3 & 3 & 3 & 3 & 217 \\
\hline 4 & 2 & 3 & 1 & 4 & 1 & 3 & 3 & 221 \\
\hline 3 & 3 & 3 & 2 & 4 & 3 & 3 & 3 & 221 \\
\hline
\end{tabular}




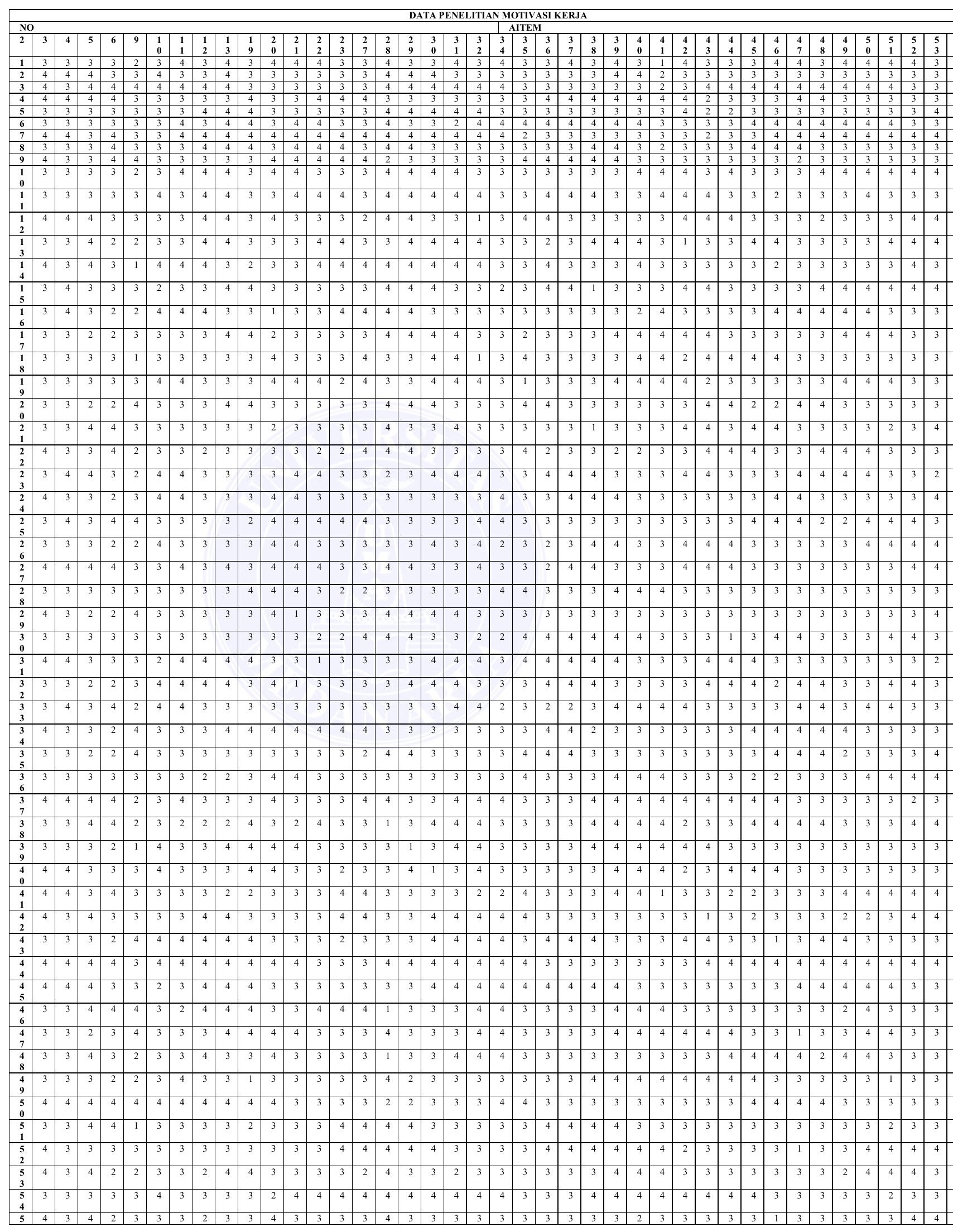




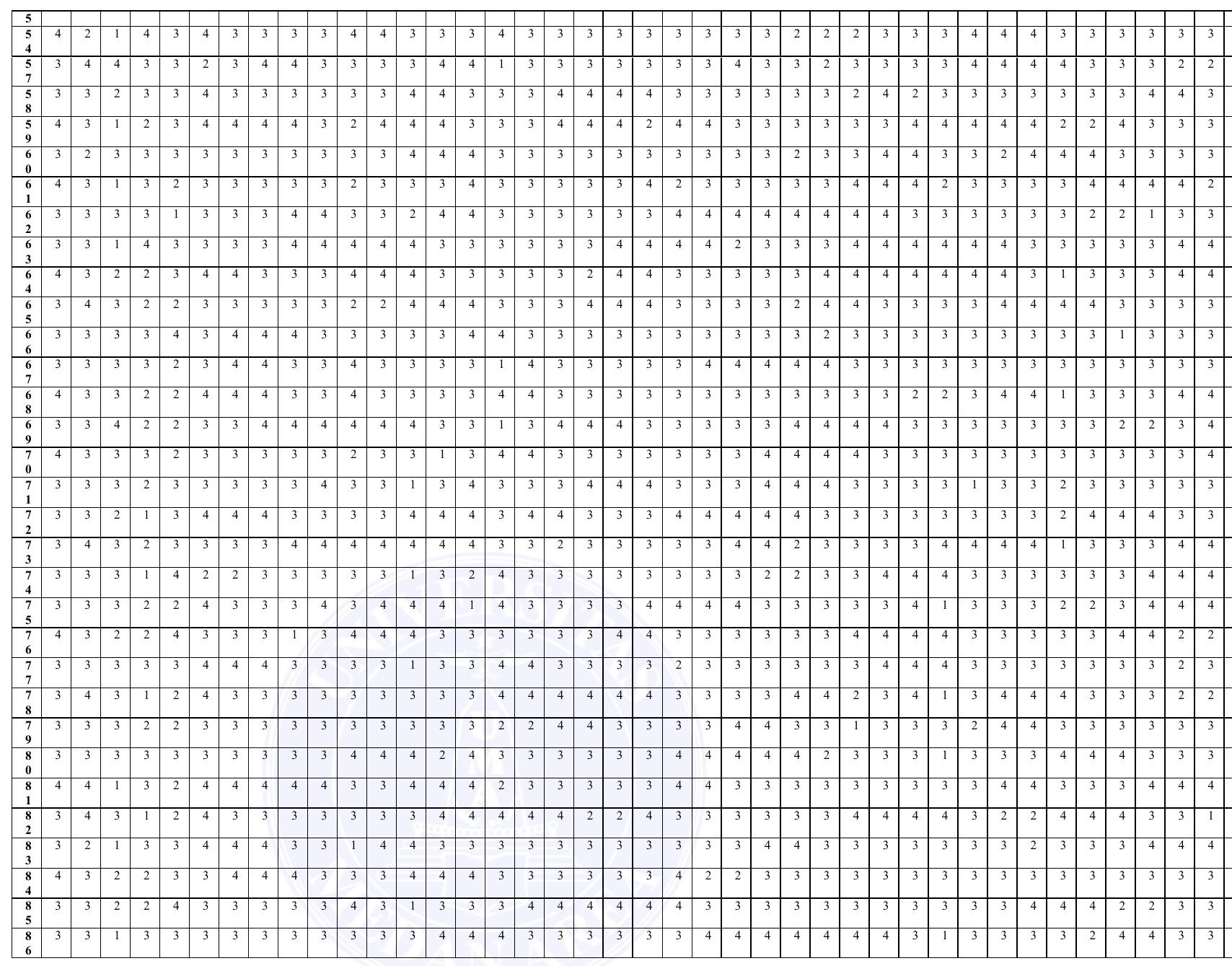




\section{LAMPIRAN D}

Hasil Uji Validitas dan Reliabilitas Skala Penelitian 


\section{Reliability}

\section{Scale: kepuasankerja}

\begin{tabular}{|c|c|c|c|}
\hline \multicolumn{4}{|c|}{ Case Processing Summary } \\
\hline & & $\mathrm{N}$ & $\%$ \\
\hline \multirow[t]{3}{*}{ Cases } & Valid & 86 & 100.0 \\
\hline & Excludeda & 0 & .0 \\
\hline & Total & 86 & 100.0 \\
\hline
\end{tabular}

a. Listwise deletion based on all variables in the procedure.

Reliability Statistics

\begin{tabular}{|r|r|}
\hline $\begin{array}{l}\text { Cronbach's } \\
\text { Alpha }\end{array}$ & N of Items \\
\hline .740 & 30 \\
\hline
\end{tabular}

Item Statistics

\begin{tabular}{|l|r|r|r|}
\hline & Mean & Std. Deviation & $\mathrm{N}$ \\
\hline $\mathrm{kp} 1$ & 3.4419 & .49952 & 86 \\
$\mathrm{kp} 2$ & 3.4070 & .51741 & 86 \\
$\mathrm{kp} 3$ & 3.4651 & .50171 & 86 \\
$\mathrm{kp} 4$ & 3.6047 & .49179 & 86 \\
$\mathrm{kp} 5$ & 3.3953 & .65582 & 86 \\
$\mathrm{kp} 6$ & 3.0698 & .74819 & 86 \\
$\mathrm{kp} 7$ & 3.2442 & .66750 & 86 \\
$\mathrm{kp} 8$ & 3.0814 & .53611 & 86 \\
$\mathrm{kp} 9$ & 3.0698 & .66493 & 86 \\
$\mathrm{kp} 10$ & 2.9884 & .71116 & 86 \\
$\mathrm{kp} 11$ & 2.8721 & .79404 & 86
\end{tabular}




\begin{tabular}{|l|l|l|l|} 
kp12 & 3.1512 & .77486 & 86 \\
kp13 & 3.3256 & .72667 & 86 \\
kp14 & 3.4884 & .62768 & 86 \\
kp15 & 3.4186 & .54157 & 86 \\
kp16 & 3.3023 & .79808 & 86 \\
kp17 & 3.1395 & .81404 & 86 \\
kp18 & 2.9070 & .86266 & 86 \\
kp19 & 3.0349 & .77380 & 86 \\
kp20 & 3.0814 & .78538 & 86 \\
kp21 & 3.4070 & .69245 & 86 \\
kp22 & 3.2907 & .59143 & 86 \\
kp23 & 3.1977 & .61011 & 86 \\
kp24 & 3.1744 & .75447 & 86 \\
kp25 & 3.3140 & .57928 & 86 \\
kp26 & 3.2209 & .62122 & 86 \\
kp27 & 3.1860 & .71145 & 86 \\
kp28 & 3.2442 & .75047 & 86 \\
kp29 & 3.3256 & .56239 & 86 \\
kp30 & 3.3605 & .55121 & 86 \\
\hline
\end{tabular}

Item-Total Statistics

\begin{tabular}{|l|r|r|r|r|}
\hline & $\begin{array}{c}\text { Scale Mean if } \\
\text { Item Deleted }\end{array}$ & $\begin{array}{c}\text { Scale Variance if } \\
\text { Item Deleted }\end{array}$ & $\begin{array}{c}\text { Corrected Item- } \\
\text { Total Correlation }\end{array}$ & $\begin{array}{c}\text { Cronbach's } \\
\text { Alpha if Item } \\
\text { Deleted }\end{array}$ \\
\hline kp1 & 93.7674 & 45.781 & .354 & .734 \\
kp2 & 93.8023 & 46.137 & .391 & .737 \\
kp3 & 93.7442 & 44.498 & .347 & .726 \\
kp4 & 93.6047 & 46.383 & .367 & .738 \\
kp5 & 93.8140 & 45.683 & .384 & .738 \\
kp6 & 94.1395 & 43.086 & .317 & .723 \\
kp7 & 93.9651 & 44.622 & .300 & .731 \\
kp8 & 94.1279 & 45.783 & .331 & .735 \\
kp9 & 94.1395 & 45.298 & .324 & .736
\end{tabular}




\begin{tabular}{|c|c|c|c|c|}
\hline kp10 & 94.2209 & 43.798 & .366 & 727 \\
\hline kp11 & 94.3372 & 43.614 & .334 & 728 \\
\hline kp12 & 94.0581 & 44.620 & .344 & 735 \\
\hline kp13 & 93.8837 & 48.386 & -.216 & 757 \\
\hline kp14 & 93.7209 & 46.651 & .082 & 743 \\
\hline kp15 & 93.7907 & 44.850 & .359 & 29 \\
\hline kp16 & 93.9070 & 43.238 & .369 & 726 \\
\hline kp17 & 94.0698 & 44.466 & .341 & 35 \\
\hline kp18 & 94.3023 & 42.919 & .361 & 726 \\
\hline kp19 & 94.1744 & 45.463 & .361 & 740 \\
\hline kp20 & 94.1279 & 45.125 & .390 & 738 \\
\hline kp21 & 93.8023 & 45.290 & .312 & 736 \\
\hline kp22 & 93.9186 & 44.852 & .321 & 730 \\
\hline kp23 & 94.0116 & 43.847 & .436 & 724 \\
\hline kp24 & 94.0349 & 43.493 & .370 & 726 \\
\hline kp25 & 93.8953 & 45.107 & .396 & 732 \\
\hline kp26 & 93.9884 & 45.282 & .348 & 734 \\
\hline kp27 & 94.0233 & 45.647 & .366 & 139 \\
\hline kp28 & 93.9651 & 43.822 & .338 & 728 \\
\hline kp29 & 93.8837 & 45.680 & .330 & 35 \\
\hline kp30 & 93.8488 & 46.977 & .061 & \\
\hline
\end{tabular}




\section{Reliability}

\section{Scale: motivasikerja}

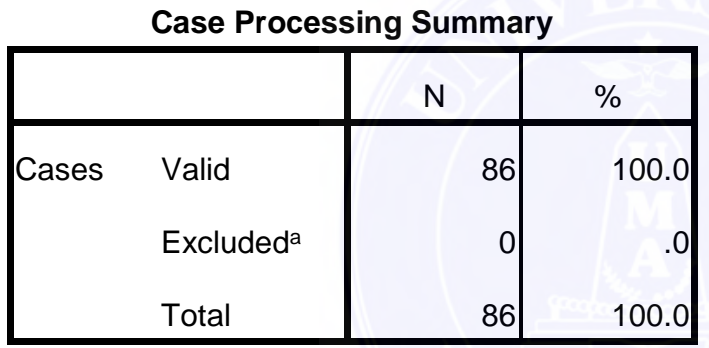

a. Listwise deletion based on all variables in the procedure.

\section{Reliability Statistics}

\begin{tabular}{|r|r|}
\hline $\begin{array}{c}\text { Cronbach's } \\
\text { Alpha }\end{array}$ & N of Items \\
\hline .792 & 70 \\
\hline
\end{tabular}

\begin{tabular}{|l|r|r|r|}
\hline & \multicolumn{1}{|c|}{ Item Statistics } \\
\hline mk1 & Mean & Std. Deviation & $\mathrm{N}$ \\
$\mathrm{mk2}$ & 3.3953 & .49179 & 86 \\
$\mathrm{mk3}$ & 3.3721 & .48620 & 86 \\
$\mathrm{mk4}$ & 3.2326 & .50116 & 86 \\
& 2.9535 & .85277 & 86
\end{tabular}




\begin{tabular}{|c|c|c|c|}
\hline mk5 & 2.8140 & .83330 & 86 \\
\hline mk6 & 2.7791 & .80295 & 86 \\
\hline mk7 & 2.9884 & .84706 & 86 \\
\hline mk8 & 3.1512 & .69481 & 86 \\
\hline mk9 & 3.2791 & .56675 & 86 \\
\hline mk10 & 3.3023 & .53291 & 86 \\
\hline mk11 & 3.2907 & .57120 & 86 \\
\hline mk12 & 3.3605 & .61190 & 86 \\
\hline mk13 & 3.2558 & .59776 & 86 \\
\hline mk14 & 3.3256 & .56239 & 86 \\
\hline mk15 & 3.3023 & .57537 & 86 \\
\hline mk16 & 3.0814 & .67240 & 86 \\
\hline mk17 & 3.0698 & .71605 & 86 \\
\hline mk18 & 3.1512 & .67767 & 86 \\
\hline mk19 & 3.2674 & .71000 & 86 \\
\hline mk20 & 3.2791 & .62593 & 86 \\
\hline mk21 & 3.2209 & .77309 & 86 \\
\hline mk22 & 3.2326 & .64488 & 86 \\
\hline mk23 & 3.2907 & .62996 & 86 \\
\hline mk24 & 3.3256 & .67635 & 86 \\
\hline mk25 & 3.3023 & .73676 & 86 \\
\hline mk26 & 3.2326 & .76195 & 86 \\
\hline mk27 & 3.2674 & .85988 & 86 \\
\hline mk28 & 3.3256 & .60278 & 86 \\
\hline mk29 & 3.3488 & .56916 & 86 \\
\hline mk30 & 3.3488 & .56916 & 86 \\
\hline mk31 & 3.3372 & .66174 & 86 \\
\hline mk32 & 3.2558 & .57775 & 86 \\
\hline mk33 & 3.1163 & .78843 & 86 \\
\hline mk34 & 3.2209 & .58211 & 86 \\
\hline mk35 & 3.2442 & .57263 & 86 \\
\hline mk36 & 3.2791 & .52359 & 86 \\
\hline mk37 & 3.3023 & .63375 & 86 \\
\hline
\end{tabular}




\begin{tabular}{|c|c|c|c|}
\hline mk38 & 3.3837 & .61680 & 86 \\
\hline mk39 & 3.3023 & .61491 & 86 \\
\hline mk40 & 3.2093 & .72138 & 86 \\
\hline mk41 & 3.3023 & .61491 & 86 \\
\hline mk42 & 3.2791 & .64445 & 86 \\
\hline mk43 & 3.1279 & .74828 & 86 \\
\hline mk44 & 3.2093 & .59639 & 86 \\
\hline mk45 & 3.2326 & .69746 & 86 \\
\hline mk46 & 3.2907 & .64837 & 86 \\
\hline mk47 & 3.1512 & .71154 & 86 \\
\hline mk48 & 3.1744 & .59788 & 86 \\
\hline mk49 & 3.2907 & .61100 & 86 \\
\hline mk50 & 3.2442 & .66750 & 86 \\
\hline mk51 & 3.2907 & .57120 & 86 \\
\hline mk52 & 3.2442 & .63126 & 86 \\
\hline mk53 & 3.3488 & .52619 & 86 \\
\hline mk54 & 3.2907 & .62996 & 86 \\
\hline mk55 & 3.3023 & .55455 & 86 \\
\hline mk56 & 3.2674 & .65842 & 86 \\
\hline mk57 & 3.3488 & .60910 & 86 \\
\hline mk58 & 3.3256 & .60278 & 86 \\
\hline mk59 & 3.3256 & .69353 & 86 \\
\hline mk60 & 3.4186 & .54157 & 86 \\
\hline mk61 & 3.3837 & .61680 & 86 \\
\hline mk62 & 3.3837 & .61680 & 86 \\
\hline mk63 & 3.3256 & .58293 & 86 \\
\hline mk64 & 3.2791 & .62593 & 86 \\
\hline mk65 & 3.1744 & .63601 & 86 \\
\hline mk66 & 3.1279 & .64710 & 86 \\
\hline mk67 & 3.1279 & .62866 & 86 \\
\hline mk68 & 3.0349 & .67646 & 86 \\
\hline mk69 & 3.2442 & .59282 & 86 \\
\hline mk70 & 3.3372 & .47553 & 86 \\
\hline
\end{tabular}


Item-Total Statistics

\begin{tabular}{|c|c|c|c|c|}
\hline & $\begin{array}{l}\text { Scale Mean if } \\
\text { Item Deleted }\end{array}$ & $\begin{array}{c}\text { Scale Variance if } \\
\text { Item Deleted }\end{array}$ & $\begin{array}{l}\text { Corrected Item- } \\
\text { Total Correlation }\end{array}$ & $\begin{array}{c}\text { Cronbach's } \\
\text { Alpha if Item } \\
\text { Deleted }\end{array}$ \\
\hline $\mathrm{mk} 1$ & 223.6860 & 55.700 & .073 & .789 \\
\hline mk2 & 223.7093 & 54.773 & .304 & .780 \\
\hline mk3 & 223.8488 & 53.259 & .405 & .766 \\
\hline mk4 & 224.1279 & 53.619 & .371 & .778 \\
\hline mk5 & 224.2674 & 52.598 & .363 & .767 \\
\hline mk6 & 224.3023 & 55.696 & .311 & .797 \\
\hline $\mathrm{mk} 7$ & 224.0930 & 57.874 & -.164 & .717 \\
\hline mk8 & 223.9302 & 57.430 & -.137 & .710 \\
\hline mk9 & 223.8023 & 55.455 & .383 & .789 \\
\hline mk10 & 223.7791 & 54.974 & .354 & .783 \\
\hline mk11 & 223.7907 & 54.567 & .387 & .780 \\
\hline mk12 & 223.7209 & 54.015 & .332 & .776 \\
\hline mk13 & 223.8256 & 55.557 & .363 & .790 \\
\hline mk14 & 223.7558 & 56.187 & -.003 & .795 \\
\hline $\mathrm{mk} 15$ & 223.7791 & 57.656 & -.173 & .709 \\
\hline $\mathrm{mk} 16$ & 224.0000 & 56.518 & -.049 & .701 \\
\hline $\mathrm{mk} 17$ & 224.0116 & 58.506 & -.232 & .719 \\
\hline $\mathrm{mk} 18$ & 223.9302 & 56.866 & -.083 & .704 \\
\hline mk19 & 223.8140 & 55.330 & .361 & .791 \\
\hline mk20 & 223.8023 & 55.078 & .308 & .786 \\
\hline mk21 & 223.8605 & 53.863 & .378 & .778 \\
\hline mk22 & 223.8488 & 55.659 & .342 & .792 \\
\hline mk23 & 223.7907 & 55.862 & .323 & .794 \\
\hline mk24 & 223.7558 & 56.634 & -.060 & .702 \\
\hline mk25 & 223.7791 & 57.327 & -.125 & .710 \\
\hline mk26 & 223.8488 & 56.812 & -.080 & .706 \\
\hline mk27 & 223.8140 & 55.118 & .348 & .793 \\
\hline mk28 & 223.7558 & 53.881 & .352 & .774 \\
\hline
\end{tabular}




\begin{tabular}{|c|c|c|c|}
\hline mk29 & 223.7326 & 54.739 & .368 \\
\hline mk30 & 223.7326 & 54.998 & .337 \\
\hline mk31 & 223.7442 & 53.793 & .331 \\
\hline mk32 & 223.8256 & 55.181 & .312 \\
\hline mk33 & 223.9651 & 56.599 & -.063 \\
\hline mk34 & 223.8605 & 57.392 & 342 \\
\hline mk35 & 223.8372 & 56.161 & 302 \\
\hline mk36 & 223.8023 & 56.749 & 369 \\
\hline mk37 & 223.7791 & 57.162 & 314 \\
\hline mk38 & 223.6977 & 56.143 & 305 \\
\hline mk39 & 223.7791 & 55.868 & .325 \\
\hline mk40 & 223.8721 & 55.595 & .333 \\
\hline mk41 & 223.7791 & 56.504 & 344 \\
\hline mk42 & 223.8023 & 57.125 & 309 \\
\hline mk43 & 223.9535 & 55.433 & .343 \\
\hline mk44 & 223.8721 & 54.536 & .380 \\
\hline mk45 & 223.8488 & 55.118 & .384 \\
\hline mk46 & 223.7907 & 55.509 & .357 \\
\hline $\mathrm{mk} 47$ & 223.9302 & 54.936 & .398 \\
\hline $\mathrm{mk} 48$ & 223.9070 & 55.474 & .372 \\
\hline mk49 & 223.7907 & 54.073 & .326 \\
\hline mk50 & 223.8372 & 55.667 & .036 \\
\hline mk51 & 223.7907 & 55.791 & .042 \\
\hline mk52 & 223.8372 & 55.408 & .071 \\
\hline mk53 & 223.7326 & 55.516 & .087 \\
\hline mk54 & 223.7907 & 54.144 & .209 \\
\hline mk55 & 223.7791 & 54.009 & .265 \\
\hline mk56 & 223.8140 & 54.059 & .205 \\
\hline mk57 & 223.7326 & 53.445 & .299 \\
\hline mk58 & 223.7558 & 53.904 & .249 \\
\hline mk59 & 223.7558 & 53.010 & .296 \\
\hline mk60 & 223.6628 & 53.732 & 309 \\
\hline mk61 & 223.6977 & 53.908 & .242 \\
\hline
\end{tabular}




\begin{tabular}{|l|l|r|r|r|} 
mk62 & 223.6977 & 54.778 & .144 & .783 \\
mk63 & 223.7558 & 55.504 & .073 & .789 \\
mk64 & 223.8023 & 55.408 & .073 & .789 \\
mk65 & 223.9070 & 54.085 & .212 & .777 \\
mk66 & 223.9535 & 54.633 & .149 & .782 \\
mk67 & 223.9535 & 54.139 & .210 & .777 \\
mk68 & 224.0465 & 53.527 & .252 & .772 \\
mk69 & 223.8372 & 54.350 & .203 & .778 \\
mk70 & 223.7442 & 54.498 & .249 & .778 \\
\hline
\end{tabular}




\section{LAMPIRAN E \\ Hasil Uji Normalitas Skala Penelitian}




\section{NPar Tests}

One-Sample Kolmogorov-Smirnov Test

\begin{tabular}{|c|c|c|c|c|}
\hline & & kepuasaankerja & motivasikerja & kinerja \\
\hline \multicolumn{2}{|l|}{$N$} & 86 & 86 & 86 \\
\hline \multirow[t]{2}{*}{ Normal Parametersa } & Mean & 87.51 & 175.27 & 85.21 \\
\hline & Std. Deviation & 8.787 & 24.076 & 4.226 \\
\hline \multirow[t]{3}{*}{ Most Extreme Differences } & Absolute & .186 & .079 & .070 \\
\hline & Positive & .109 & .042 & .070 \\
\hline & Negative & -.186 & -.079 & -.070 \\
\hline \multicolumn{2}{|l|}{ Kolmogorov-Smirnov Z } & 1.726 & .733 & .653 \\
\hline \multicolumn{2}{|l|}{ Asymp. Sig. (2-tailed) } & .015 & 655 & .787 \\
\hline \multicolumn{2}{|c|}{ a. Test distribution is Normal. } & & & \\
\hline
\end{tabular}




\section{LAMPIRAN F}

Hasil Uji Linearitas Skala Penelitian 


\section{Means}

\begin{tabular}{|c|c|c|c|c|c|c|}
\hline \multicolumn{7}{|c|}{ Case Processing Summary } \\
\hline & \multicolumn{6}{|c|}{ Cases } \\
\hline & \multicolumn{2}{|c|}{ Included } & \multicolumn{2}{|c|}{ Excluded } & \multicolumn{2}{|c|}{ Total } \\
\hline & $\mathrm{N}$ & Percent & $\mathrm{N}$ & Percent & $\mathrm{N}$ & Percent \\
\hline kinerja ${ }^{*}$ kepuasankerja & 86 & $100.0 \%$ & 0 & $.0 \%$ & 86 & $100.0 \%$ \\
\hline
\end{tabular}

\section{Report}

kinerja

\begin{tabular}{|c|c|c|c|}
\hline $\begin{array}{l}\text { kepuas } \\
\text { ankerja }\end{array}$ & Mean & $\mathrm{N}$ & Std. Deviation \\
\hline 124 & 86.24 & 4 & 4.760 \\
\hline 131 & 82.00 & 1 & \\
\hline 134 & 75.00 & 2 & 4.243 \\
\hline 136 & 78.00 & 1 & \\
\hline 142 & 87.00 & 1 & 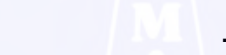 \\
\hline 143 & 88.00 & 1 & \\
\hline 148 & 81.88 & 4 & 4.578 \\
\hline 156 & 84.87 & 4 & 2.572 \\
\hline 159 & 83.98 & 4 & 3.470 \\
\hline 165 & 86.42 & 4 & 3.635 \\
\hline 167 & 86.91 & 2 & 7.191 \\
\hline 168 & 84.12 & 4 & 3.879 \\
\hline 169 & 82.78 & 1 & \\
\hline 171 & 88.66 & 4 & 2.400 \\
\hline 172 & 88.22 & 2 & 2.524 \\
\hline 173 & 86.11 & 3 & .922 \\
\hline 174 & 88.00 & 1 & \\
\hline 175 & 91.00 & 1 & \\
\hline 176 & 85.82 & 1 & \\
\hline 177 & 83.15 & 4 & 3.767 \\
\hline 178 & 83.55 & 1 & \\
\hline 179 & 85.00 & 1 & \\
\hline
\end{tabular}




\begin{tabular}{|l|r|r|r|}
180 & 89.55 & 1 & \\
185 & 90.00 & 1 & \\
186 & 83.76 & 7 & 3.691 \\
187 & 96.00 & 1 & \\
189 & 85.08 & 4 & 2.041 \\
194 & 98.00 & 1 & \\
195 & 84.94 & 4 & 4.110 \\
197 & 87.00 & 1 & \\
198 & 84.81 & 3 & 3.607 \\
208 & 86.00 & 2 & 3.776 \\
209 & 82.78 & 4 & 1.478 \\
217 & 85.56 & 2 & 6.131 \\
218 & 86.37 & 4 & 2.566 \\
Total & 85.21 & 86 & 4.226 \\
\hline
\end{tabular}

ANOVA Table

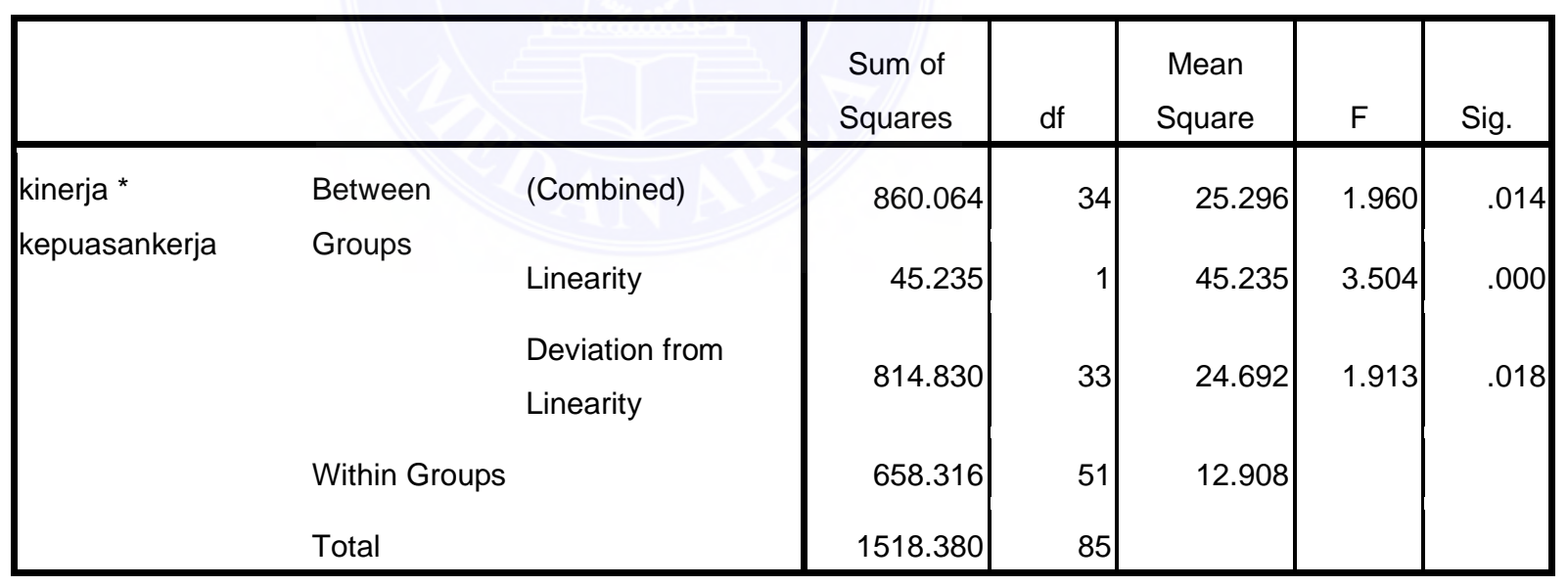

Measures of Association

\begin{tabular}{|l|r|r|r|r|}
\hline & \multicolumn{1}{|c|}{$\mathrm{R}$} & $\mathrm{R}$ Squared & \multicolumn{1}{c|}{ Eta } & Eta Squared \\
\hline kinerja * kepuasankerja & .173 & .030 & .753 & .566 \\
\hline
\end{tabular}




\section{Means}

Case Processing Summary

\begin{tabular}{|l|r|r|r|r|r|r|}
\hline \multirow{2}{*}{} & \multicolumn{9}{c|}{ Cases } \\
\cline { 2 - 7 } & \multicolumn{2}{|c|}{ Included } & \multicolumn{2}{c|}{ Excluded } & \multicolumn{2}{c|}{ Total } \\
\cline { 2 - 7 } & $\mathrm{N}$ & Percent & $\mathrm{N}$ & Percent & $\mathrm{N}$ & Percent \\
\hline kinerja * motivasikerja & 86 & $100.0 \%$ & & $.0 \%$ & 86 & $100.0 \%$ \\
\hline
\end{tabular}

Report

\begin{tabular}{|c|c|c|c|}
\hline $\begin{array}{l}\text { motivas } \\
\text { ikerja }\end{array}$ & Mean & $\mathrm{N}$ & Std. Deviation \\
\hline 68 & 84.50 & 2 & 3.536 \\
\hline 69 & 80.85 & 3 & 2.627 \\
\hline 70 & 82.16 & 2 & 5.890 \\
\hline 71 & 72.00 & 1 & \\
\hline 77 & 82.24 & 6 & 3.733 \\
\hline 78 & 86.52 & 3 & 2.717 \\
\hline 81 & 85.27 & 4 & 3.951 \\
\hline 85 & 92.00 & 1 & \\
\hline 86 & 83.70 & 3 & 1.950 \\
\hline 87 & 84.60 & 9 & 3.972 \\
\hline 88 & 83.80 & 9 & 3.100 \\
\hline 89 & 85.70 & 15 & 2.939 \\
\hline 90 & 86.34 & 4 & 3.999 \\
\hline 91 & 87.85 & 1 & \\
\hline 92 & 86.03 & 2 & 2.786 \\
\hline
\end{tabular}




\begin{tabular}{|l|r|r|r|}
93 & 86.82 & 1 & \\
96 & 87.83 & 3 & 3.382 \\
97 & 90.66 & 2 & 7.545 \\
98 & 86.52 & 12 & 4.007 \\
99 & 87.00 & 1 & \\
104 & 98.00 & 1 & \\
110 & 81.83 & 1 & \\
Total & 85.21 & 86 & 4.226 \\
\hline
\end{tabular}

ANOVA Table

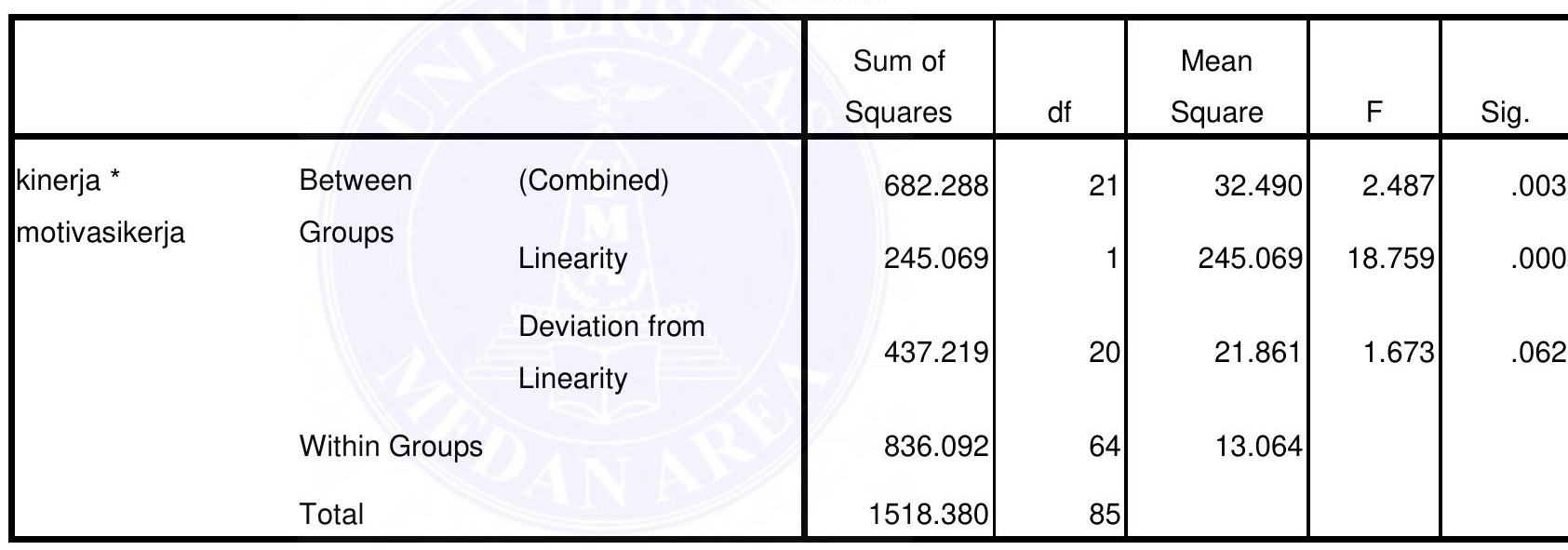

Measures of Association

\begin{tabular}{|l|r|r|r|r|}
\hline & $\mathrm{R}$ & $\mathrm{R}$ Squared & Eta & Eta Squared \\
\hline kinerja * motivasikerja & .402 & .161 & .670 & .449 \\
\hline
\end{tabular}




\section{Means}

Case Processing Summary

\begin{tabular}{|c|c|c|c|c|c|c|}
\hline & \multicolumn{6}{|c|}{ Cases } \\
\hline & \multicolumn{2}{|c|}{ Included } & \multicolumn{2}{|c|}{ Excluded } & \multicolumn{2}{|c|}{ Total } \\
\hline & $\mathrm{N}$ & Percent & $\mathrm{N}$ & Percent & $\mathrm{N}$ & Percent \\
\hline kinerja * motivasikerja & 86 & $100.0 \%$ & 0 & $.0 \%$ & 86 & $100.0 \%$ \\
\hline
\end{tabular}

Report

\begin{tabular}{|l|r|r|r|}
\hline $\begin{array}{l}\text { kinerja } \\
\text { motivas } \\
\text { ikerja }\end{array}$ & Mean & $\mathrm{N}$ & Std. Deviation \\
\hline 124 & 86.24 & 4 & 4.760 \\
131 & 82.00 & 1 & \\
134 & 75.00 & 2 & 4.243 \\
136 & 78.00 & 1 & \\
142 & 87.00 & 1 & \\
143 & 88.00 & 1 & \\
148 & 81.88 & 4 & 4.578 \\
156 & 84.87 & 4 & 2.572 \\
159 & 83.98 & 4 & 3.470
\end{tabular}




\begin{tabular}{|c|c|c|c|}
\hline 165 & 86.42 & 4 & 3.635 \\
\hline 167 & 86.91 & 2 & 7.191 \\
\hline 168 & 84.12 & 4 & 3.879 \\
\hline 169 & 82.78 & 1 & \\
\hline 171 & 88.66 & 4 & 2.400 \\
\hline 172 & 88.22 & 2 & 2.524 \\
\hline 173 & 86.11 & 3 & .922 \\
\hline 174 & 88.00 & 1 & \\
\hline 175 & 91.00 & 1 & \\
\hline 176 & 85.82 & 1 & \\
\hline 177 & 83.15 & 4 & 3.767 \\
\hline 178 & 83.55 & 1 & \\
\hline 179 & 85.00 & 1 & \\
\hline 180 & 89.55 & 1 & \\
\hline 185 & 90.00 & 1 & \\
\hline 186 & 83.76 & 7 & 3.691 \\
\hline 187 & 96.00 & 1 & \\
\hline 189 & 85.08 & 4 & 2.041 \\
\hline 194 & 98.00 & 1 & \\
\hline 195 & 84.94 & 4 & 4.110 \\
\hline 197 & 87.00 & 1 & \\
\hline 198 & 84.81 & 3 & 3.607 \\
\hline 208 & 86.00 & 2 & 3.776 \\
\hline 209 & 82.78 & 4 & 1.478 \\
\hline 217 & 85.56 & 2 & 6.131 \\
\hline 218 & 86.37 & 4 & 2.566 \\
\hline Total & & 86 & \\
\hline
\end{tabular}




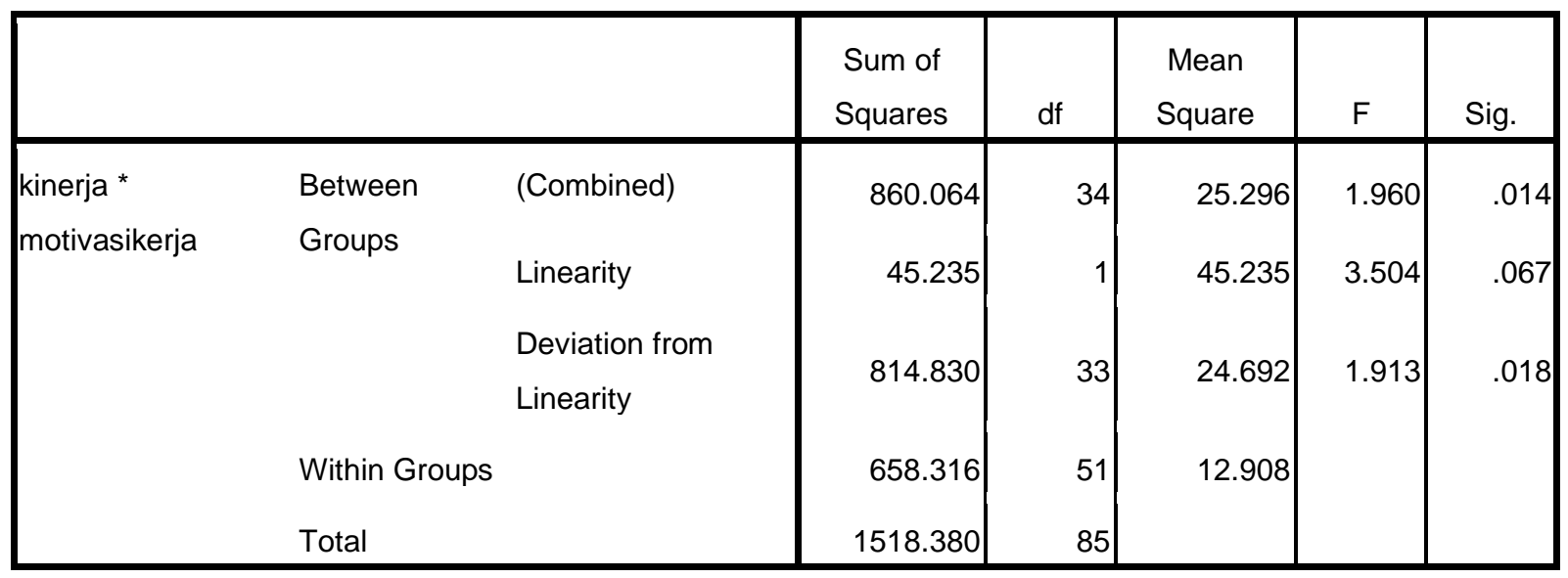




\section{LAMPIRAN G}

Hasil Uji Asumsi dan Hipotesis Skala Penelitian 


\section{Hipotesis 1}

\section{Regression}

\begin{tabular}{|c|c|c|c|}
\hline \multicolumn{4}{|c|}{ Descriptive Statistics } \\
\hline & Mean & Std. Deviation & $\mathrm{N}$ \\
\hline kinerja & 85.21 & 4.226 & 86 \\
\hline kepuasankerja & 175.27 & 24.076 & 86 \\
\hline
\end{tabular}

\begin{tabular}{|ll|r|r|}
\hline \multicolumn{2}{|c|}{ Correlations } \\
\hline Pearson Correlation & kinerja & kepuasankerja \\
& kepuasankerja & 1.000 & .173 \\
& kinerja & .173 & 1.000 \\
\hline Sig. (1-tailed) & kepuasankerja & .056 & .056 \\
& kinerja & 86 & 86 \\
\hline $\mathrm{N}$ & kepuasankerja & 86 & 86 \\
\hline
\end{tabular}

\begin{tabular}{|c|c|c|c|c|c|c|c|c|c|}
\hline \multicolumn{10}{|c|}{ Model Summary } \\
\hline \multirow[b]{2}{*}{ Model } & \multirow[b]{2}{*}{$\mathrm{R}$} & \multirow[b]{2}{*}{ R Square } & \multirow[b]{2}{*}{$\begin{array}{l}\text { Adjusted R } \\
\text { Square }\end{array}$} & \multirow[b]{2}{*}{$\begin{array}{l}\text { Std. Error of } \\
\text { the Estimate }\end{array}$} & \multicolumn{5}{|c|}{ Change Statistics } \\
\hline & & & & & $\begin{array}{l}\text { R Square } \\
\text { Change }\end{array}$ & F Change & df1 & $\mathrm{df} 2$ & $\begin{array}{c}\text { Sig. F } \\
\text { Change }\end{array}$ \\
\hline 1 & $.173^{a}$ & .030 & .018 & 4.188 & .030 & 2.579 & 1 & 84 & .112 \\
\hline
\end{tabular}

a. Predictors: (Constant), kepuasankerja 


\begin{tabular}{|c|c|c|c|c|c|c|}
\hline \multicolumn{7}{|c|}{ ANOVA $^{b}$} \\
\hline & & Sum of Squares & df & Mean Square & $\mathrm{F}$ & Sig. \\
\hline \multirow[t]{3}{*}{1} & Regression & 45.235 & 1 & 45.235 & 2.579 & $.112^{\mathrm{a}}$ \\
\hline & Residual & 1473.145 & 84 & 17.537 & & \\
\hline & Total & 1518.380 & 85 & & & \\
\hline
\end{tabular}

a. Predictors: (Constant), kepuasankerja

b. Dependent Variable: kinerja

Coefficients $^{a}$

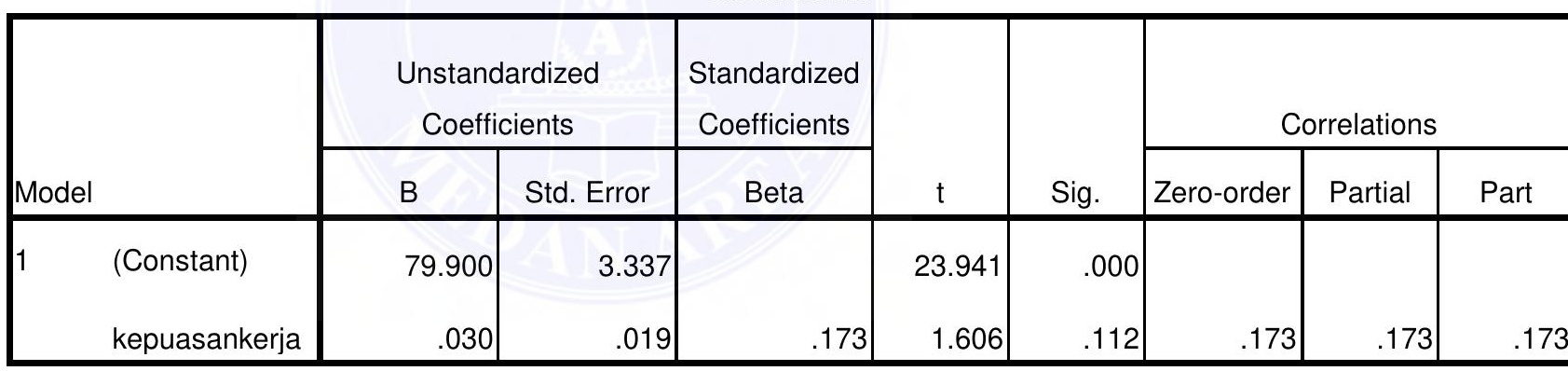

a. Dependent Variable: kinerja 


\section{Hipotesis 2}

\section{Regression}

\begin{tabular}{|l|r|r|r|}
\multicolumn{1}{l|}{ Descriptive Statistics } \\
\hline \\
\cline { 1 - 3 } & \multicolumn{1}{|c|}{ Mean } & Std. Deviation & \multicolumn{1}{c|}{$\mathrm{N}$} \\
\hline kinerja & 85.21 & 4.226 & 86 \\
motivasikerja & 87.51 & 8.787 & 86 \\
\hline
\end{tabular}

\begin{tabular}{|ll|r|r|}
\hline \multicolumn{2}{|c|}{ Correlations } \\
\hline Pearson Correlation & kinerja & motivasikerja \\
& motivasikerja & 1.000 & .402 \\
\hline Sig. (1-tailed) & kinerja & .402 & 1.000 \\
& motivasikerja & .000 & .000 \\
\hline N & kinerja & 86 & 86 \\
& motivasikerja & 86 & 86 \\
\hline
\end{tabular}

\begin{tabular}{|c|c|c|c|c|c|c|c|c|c|}
\hline \multicolumn{10}{|c|}{ Model Summary } \\
\hline \multirow[b]{2}{*}{ Model } & \multirow[b]{2}{*}{$\mathrm{R}$} & \multirow[b]{2}{*}{ R Square } & \multirow[b]{2}{*}{$\begin{array}{l}\text { Adjusted R } \\
\text { Square }\end{array}$} & \multirow[b]{2}{*}{$\begin{array}{l}\text { Std. Error of } \\
\text { the Estimate }\end{array}$} & \multicolumn{5}{|c|}{ Change Statistics } \\
\hline & & & & & $\begin{array}{l}\text { R Square } \\
\text { Change }\end{array}$ & F Change & df1 & df2 & $\begin{array}{c}\text { Sig. F } \\
\text { Change }\end{array}$ \\
\hline 1 & $.402^{\mathrm{a}}$ & .161 & .151 & 3.893 & .161 & 16.167 & 1 & 84 & .000 \\
\hline
\end{tabular}


Model Summary

\begin{tabular}{|c|c|c|c|c|c|c|c|c|c|}
\hline \multirow[b]{2}{*}{ Model } & \multirow[b]{2}{*}{$\mathrm{R}$} & \multirow[b]{2}{*}{ R Square } & \multirow[b]{2}{*}{$\begin{array}{l}\text { Adjusted R } \\
\text { Square }\end{array}$} & \multirow[b]{2}{*}{$\begin{array}{l}\text { Std. Error of } \\
\text { the Estimate }\end{array}$} & \multicolumn{5}{|c|}{ Change Statistics } \\
\hline & & & & & $\begin{array}{l}\text { R Square } \\
\text { Change }\end{array}$ & F Change & df1 & $\mathrm{df} 2$ & $\begin{array}{c}\text { Sig. F } \\
\text { Change }\end{array}$ \\
\hline 1 & $.402^{\mathrm{a}}$ & .161 & .151 & 3.893 & .161 & 16.167 & 1 & 84 & .000 \\
\hline
\end{tabular}

a. Predictors: (Constant), motivasikerja

ANOVA $^{b}$

\begin{tabular}{|c|c|c|c|c|c|c|}
\hline \multicolumn{2}{|c|}{ Model } & Sum of Squares & $d f$ & Mean Square & $\mathrm{F}$ & Sig. \\
\hline \multirow[t]{3}{*}{1} & Regression & 245.069 & 1 & 245.069 & 16.167 & $.000^{\mathrm{a}}$ \\
\hline & Residual & 1273.311 & 84 & 15.158 & & \\
\hline & Total & 1518.380 & 85 & & & \\
\hline
\end{tabular}

a. Predictors: (Constant), motivasikerja

b. Dependent Variable: kinerja

\section{Coefficients $^{\mathrm{a}}$}

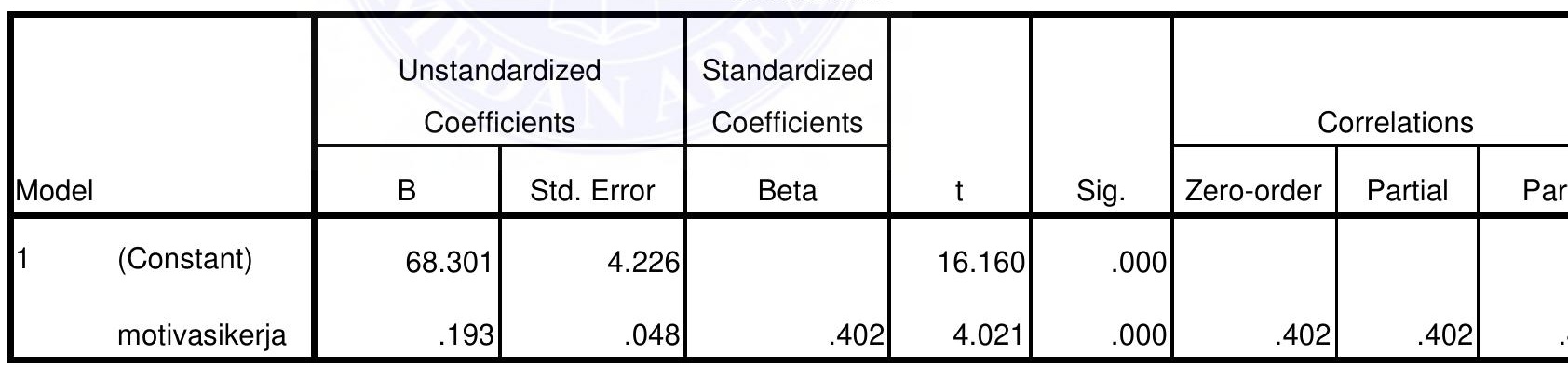

a. Dependent Variable: kinerja 


\section{Hipotesis 3}

\section{Regression}

\begin{tabular}{|c|c|c|c|}
\hline \multicolumn{4}{|c|}{ Descriptive Statistics } \\
\hline & Mean & Std. Deviation & $\mathrm{N}$ \\
\hline kinerja & 85.21 & 4.226 & \\
\hline kepuasankerja & 175.27 & 24.076 & \\
\hline motivasikerja & 87.51 & 8.787 & \\
\hline
\end{tabular}


Model Summary

\begin{tabular}{|c|c|c|c|c|c|c|c|c|c|}
\hline \multirow[b]{2}{*}{ Model } & \multirow[b]{2}{*}{$\mathrm{R}$} & \multirow[b]{2}{*}{ R Square } & \multirow[b]{2}{*}{$\begin{array}{c}\text { Adjusted R } \\
\text { Square }\end{array}$} & \multirow[b]{2}{*}{$\begin{array}{l}\text { Std. Error of } \\
\text { the Estimate }\end{array}$} & \multicolumn{5}{|c|}{ Change Statistics } \\
\hline & & & & & $\begin{array}{l}\text { R Square } \\
\text { Change }\end{array}$ & F Change & df1 & $\mathrm{df} 2$ & $\begin{array}{l}\text { Sig. F } \\
\text { Change }\end{array}$ \\
\hline 1 & $.410^{\mathrm{a}}$ & .168 & .148 & 3.900 & .168 & 8.406 & 2 & 83 & .000 \\
\hline
\end{tabular}

a. Predictors: (Constant), motivasikerja,

kepuasankerja

Coefficients $^{a}$

\begin{tabular}{|c|c|c|c|c|c|c|c|c|c|}
\hline \multirow{2}{*}{\multicolumn{2}{|c|}{ Model }} & \multicolumn{2}{|c|}{$\begin{array}{c}\text { Unstandardized } \\
\text { Coefficients }\end{array}$} & \multirow{2}{*}{$\begin{array}{c}\begin{array}{c}\text { Standardized } \\
\text { Coefficients }\end{array} \\
\text { Beta }\end{array}$} & \multirow[b]{2}{*}{$\mathrm{t}$} & \multirow[b]{2}{*}{ Sig. } & \multicolumn{3}{|c|}{ Correlations } \\
\hline & & B & Std. Error & & & & Zero-order & Partial & Part \\
\hline \multirow[t]{3}{*}{1} & (Constant) & 66.470 & 4.764 & & 13.953 & .000 & & & \\
\hline & kepuasankerja & .015 & .018 & .086 & .838 & .404 & .173 & .092 & .084 \\
\hline & motivasikerja & .184 & .049 & .382 & 3.720 & .000 & .402 & .378 & .372 \\
\hline
\end{tabular}

a. Dependent Variable: kinerja 


\section{LAMPIRAN H}

Struktur Organisasi 


\section{Struktur Organisasi Dinas Kesehatan KabupatenTapanuli Utara}

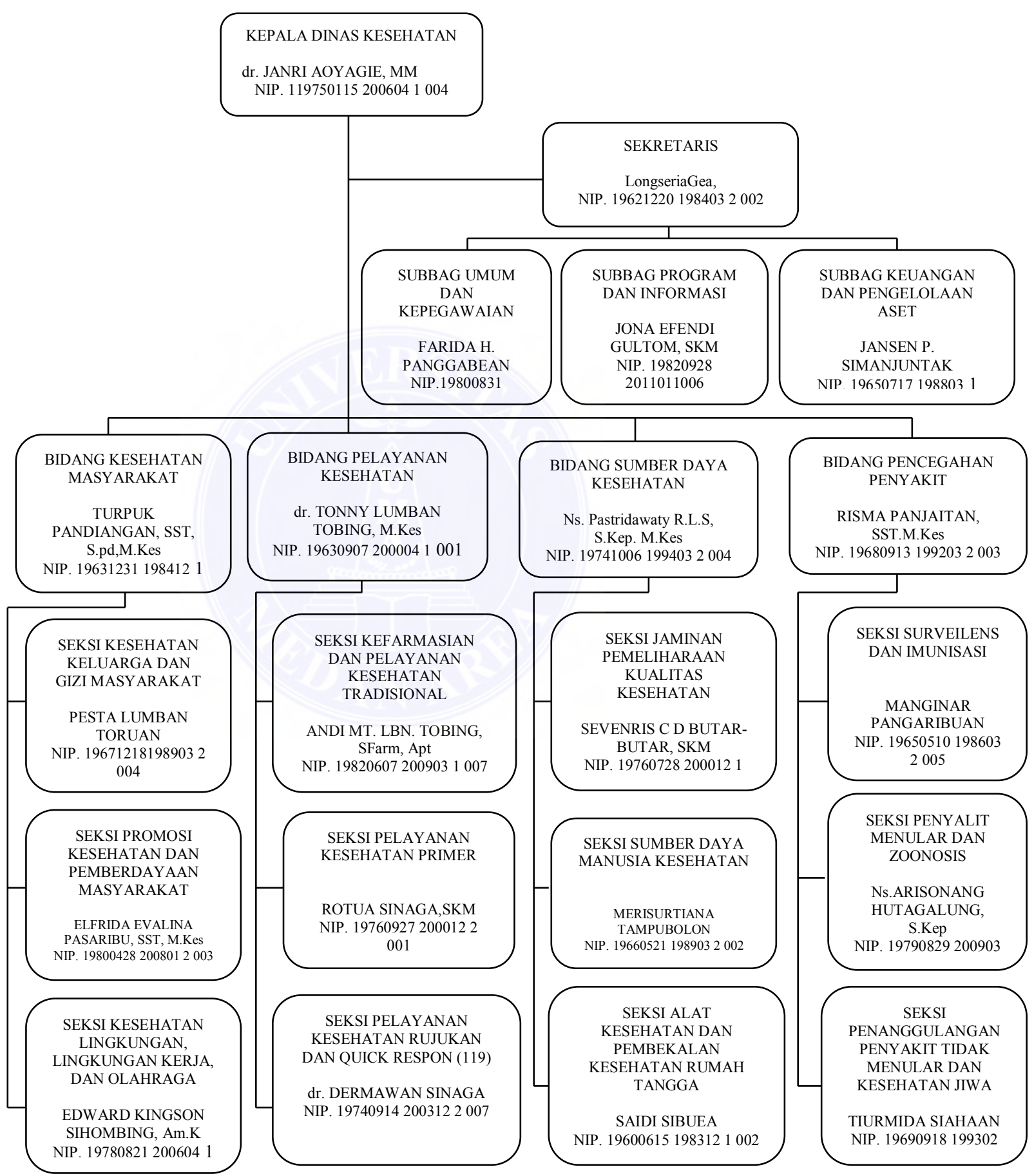


LAMPIRAN I

Dokumen Kinerja Pegawai/SKP (Sasaran Kerja

Pegawai) 
Nilai Capaian SKP dinyatakan dengan angka dan keterangan sebagai berikut :

\begin{tabular}{|l|l|}
\hline \multicolumn{1}{|c|}{ Angka } & \multicolumn{1}{c|}{ Predikat } \\
\hline $91-$ Ke atas & Sangat Baik \\
\hline $76-90$ & Baik \\
\hline $61-75$ & Cukup \\
\hline $51-60$ & Kurang \\
\hline $50-$ Ke bawah & Sangat Kurang \\
\hline
\end{tabular}

Berikut ini untuk menilai kualitas output, digunakan kriteria sebagai berikut :

\begin{tabular}{|l|l|}
\hline Kriteria Nilai & \multicolumn{1}{c|}{ Keterangan } \\
\hline $\mathbf{9 1 - 1 0 0}$ & $\begin{array}{l}\text { Hasil kerja sempurna, tidak ada kesalahan, tidak ada } \\
\text { revisi, dan pelayanan diatas standar yang ditentukan } \\
\text { dan lain-lain. }\end{array}$ \\
\hline $\mathbf{7 6 - 9 0}$ & $\begin{array}{l}\text { Hasil kerja mempunyai 1 atau 2 kesalahan kecil, tidak } \\
\text { ada kesalahan besar, revisi, dan pelayanan sesuai } \\
\text { standar yang telah ditentukan dan lain - lain. }\end{array}$ \\
\hline $\mathbf{6 1 - 7 5}$ & $\begin{array}{l}\text { Hasil kerja mempunyai 3 atau 4 kesalahan kecil, dan } \\
\text { tidak ada kesalahan besar, revisi, dan pelayanan cukup } \\
\text { memenuhi standar yang ditentukan. }\end{array}$ \\
\hline $\mathbf{5 1 - 6 0}$ & $\begin{array}{l}\text { Hasil kerja mempunyai 5 kesalahan kecil dan ada } \\
\text { kesalahan besar, revisi, dan pelayanan tidak cukup } \\
\text { memenuhi standar yang ditentukan dan lain - lain }\end{array}$ \\
\hline $\mathbf{5 0}$ ke bawah & $\begin{array}{l}\text { Hasil kerja mempunyai lebih dari 5 kesalahan kecil } \\
\text { dan ada kesalahan besar, kurang memuaskan, revisi, } \\
\text { pelayanan dibawah standar yang ditentukan dan lain - } \\
\text { lain. }\end{array}$ \\
\hline
\end{tabular}




\begin{tabular}{|c|c|c|c|c|}
\hline \multirow[t]{2}{*}{ No } & \multirow{2}{*}{$\begin{array}{l}\text { Nama } \\
\text { Pegawai }\end{array}$} & \multirow[t]{2}{*}{ Jabatan } & \multicolumn{2}{|c|}{ Nilai Prestasi Kerja } \\
\hline & & & Tahun 2015 & Tahun 2016 \\
\hline 1. & $\begin{array}{l}\text { Farida H. } \\
\text { Panggabean }\end{array}$ & $\begin{array}{l}\text { Ka. Subbag. } \\
\text { Umum dan } \\
\text { Kepegawaian }\end{array}$ & 87,80 ( Baik ) & 88,00 ( Baik ) \\
\hline 2. & $\begin{array}{l}\text { Lince } \\
\text { Simanjuntak }\end{array}$ & $\begin{array}{l}\text { Staf Subbag. } \\
\text { Umum dan } \\
\text { Kepegawaian }\end{array}$ & 81,76 ( Baik) & 78,80 ( Baik ) \\
\hline 3. & Risma Purba & $\begin{array}{l}\text { Staf Subbag. } \\
\text { Umum dan } \\
\text { Kepegawaian }\end{array}$ & 83,20 ( Baik) & 85,77 ( Baik ) \\
\hline 4. & $\begin{array}{l}\text { Rikson } \\
\text { Siringo-ringo }\end{array}$ & $\begin{array}{l}\text { Staf Subbag. } \\
\text { Umum dan } \\
\text { Kepegawaian }\end{array}$ & 87,20 ( Baik ) & 86,00 ( Baik ) \\
\hline 5. & $\begin{array}{l}\text { Rutti G. } \\
\text { Pasaribu }\end{array}$ & $\begin{array}{l}\text { Staf Subbag. } \\
\text { Umum dan } \\
\text { Kepegawaian }\end{array}$ & 82,57 ( Baik ) & 81,76 ( Baik) \\
\hline 6. & $\begin{array}{l}\text { Brolin Marno } \\
\text { Otnie }\end{array}$ & $\begin{array}{l}\text { Staf Subbag. } \\
\text { Umum dan } \\
\text { Kepegawaian }\end{array}$ & 80,33 ( Baik ) & 80,00 ( Baik ) \\
\hline 7. & $\begin{array}{l}\text { Andreas Lbn. } \\
\text { Tobing }\end{array}$ & $\begin{array}{l}\text { Staf Subbag. } \\
\text { Umum dan } \\
\text { Kepegawaian }\end{array}$ & 88,67 ( Baik ) & 84,00 ( Baik ) \\
\hline 8. & $\begin{array}{l}\text { Dumaria } \\
\text { Simanjuntak }\end{array}$ & $\begin{array}{l}\text { Staf Subbag. } \\
\text { Umum dan } \\
\text { Kepegawaian }\end{array}$ & 84,67 ( Baik & 80,00 ( Baik ) \\
\hline 9. & $\begin{array}{l}\text { Friska D. } \\
\text { Panggabean }\end{array}$ & $\begin{array}{l}\text { Staf Subbag. } \\
\text { Umum dan } \\
\text { Kepegawaian }\end{array}$ & 86,00 ( Baik ) & 82,00 ( Baik ) \\
\hline 10. & $\begin{array}{l}\text { Kristina } \\
\text { Hasibuan }\end{array}$ & $\begin{array}{l}\text { Staf Subbag. } \\
\text { Umum dan } \\
\text { Kepegawaian }\end{array}$ & 80,00 ( Baik ) & 82,57 ( Baik ) \\
\hline 11. & $\begin{array}{l}\text { Manur } \\
\text { Manalu }\end{array}$ & $\begin{array}{l}\text { Staf Subbag. } \\
\text { Umum dan } \\
\text { Kepegawaian }\end{array}$ & 82,57 ( Baik ) & 80,00 ( Baik ) \\
\hline 12. & $\begin{array}{l}\text { Jansen. P. } \\
\text { Simanjuntak }\end{array}$ & $\begin{array}{l}\text { Ka. Subbag. } \\
\text { Keuangan dan } \\
\text { Pengelolaan Aset }\end{array}$ & 80,00 ( Baik ) & 78,96 ( Baik) \\
\hline 13. & $\begin{array}{l}\text { Deddy } \\
\text { Lamsihar } \\
\text { Fernando, SE }\end{array}$ & $\begin{array}{l}\text { Staf Subbag. } \\
\text { Keuangan dan } \\
\text { Pengelolaan Aset }\end{array}$ & 80,00 ( Baik ) & 80,56 ( Baik ) \\
\hline
\end{tabular}




\begin{tabular}{|c|c|c|c|c|}
\hline 14. & $\begin{array}{l}\text { James } \\
\text { Manalu, } \\
\text { Am.kep } \\
\end{array}$ & $\begin{array}{l}\text { Staf Subbag. } \\
\text { Keuangan dan } \\
\text { Pengelolaan Aset }\end{array}$ & 89,43 ( Baik ) & 88,65 ( Baik ) \\
\hline 15. & $\begin{array}{l}\text { Suandi } \\
\text { Simorangkir }\end{array}$ & $\begin{array}{l}\text { Staf Subbag. } \\
\text { Keuangan dan } \\
\text { Pengelolaan Aset }\end{array}$ & 86,66 ( Baik ) & 86,20 ( Baik) \\
\hline 16. & $\begin{array}{l}\text { Andrian } \\
\text { Hutabarat, } \\
\text { A.Md }\end{array}$ & $\begin{array}{l}\text { Staf Subbag. } \\
\text { Keuangan dan } \\
\text { Pengelolaan Aset }\end{array}$ & 89,77 ( Baik ) & 89,33 ( Baik) \\
\hline 17. & $\begin{array}{l}\text { Hisar } \\
\text { Situmeang }\end{array}$ & $\begin{array}{l}\text { Staf Subbag. } \\
\text { Keuangan dan } \\
\text { Pengelolaan Aset }\end{array}$ & 84,67 ( Baik ) & 81,00 ( Baik ) \\
\hline 18. & $\begin{array}{l}\text { Baginda } \\
\text { Silaban }\end{array}$ & $\begin{array}{l}\text { Staf Subbag. } \\
\text { Keuangan dan } \\
\text { Pengelolaan Aset }\end{array}$ & 87,00 ( Baik ) & 86,67 ( Baik) \\
\hline 19. & $\begin{array}{l}\text { Sartana H. } \\
\text { Siburian }\end{array}$ & $\begin{array}{l}\text { Staf Subbag. } \\
\text { Keuangan dan } \\
\text { Pengelolaan Aset }\end{array}$ & 88,65 ( Baik ) & 89,67 ( Baik) \\
\hline 20. & Petrus Siregar & $\begin{array}{l}\text { Staf Subbag. } \\
\text { Keuangan dan } \\
\text { Pengelolaan Aset }\end{array}$ & 83,57 ( Baik ) & 82,00 ( Baik) \\
\hline 21. & $\begin{array}{l}\text { Erniwati } \\
\text { Saragih }\end{array}$ & $\begin{array}{l}\text { Staf Subbag. } \\
\text { Keuangan dan } \\
\text { Pengelolaan Aset }\end{array}$ & 80,00 ( Baik ) & 83,67 ( Baik ) \\
\hline 22. & $\begin{array}{l}\text { Susi Ida } \\
\text { Panggabean }\end{array}$ & $\begin{array}{l}\text { Staf Subbag. } \\
\text { Keuangan dan } \\
\text { Pengelolaan Aset }\end{array}$ & 87,00 ( Baik ) & 84,65 ( Baik ) \\
\hline 23. & $\begin{array}{l}\text { Ariestina } \\
\text { Siregar }\end{array}$ & $\begin{array}{l}\text { Staf Subbag. } \\
\text { Keuangan dan } \\
\text { Pengelolaan Aset }\end{array}$ & 82,00 ( Baik ) & 80,67 ( Baik) \\
\hline 24. & $\begin{array}{l}\text { Jona Efendi } \\
\text { Gultom, SKM }\end{array}$ & $\begin{array}{l}\text { Ka. Subbag. } \\
\text { Program dan } \\
\text { Informasi }\end{array}$ & 86,00 ( Baik ) & 89,70 ( Baik ) \\
\hline 25. & $\begin{array}{l}\text { Saut M. } \\
\text { Pakpahan }\end{array}$ & $\begin{array}{l}\text { Staf Subbag. } \\
\text { Program dan } \\
\text { Informasi }\end{array}$ & 85,34 ( Baik ) & 81,77 ( Baik) \\
\hline 26. & $\begin{array}{l}\text { Refly } \\
\text { Situmorang }\end{array}$ & $\begin{array}{l}\text { Staf Subbag. } \\
\text { Program dan } \\
\text { Informasi }\end{array}$ & 84,00 ( Baik ) & 86,00 ( Baik ) \\
\hline 27. & $\begin{array}{l}\text { Irwan } \\
\text { Manumpak } \\
\text { Nainggolan } \\
\end{array}$ & $\begin{array}{l}\text { Staf Subbag. } \\
\text { Program dan } \\
\text { Informasi }\end{array}$ & 88,27 ( Baik ) & 86,00 ( Baik) \\
\hline 28. & Basana Lestari & $\begin{array}{l}\text { Staf Subbag. } \\
\text { Program dan } \\
\text { Informasi }\end{array}$ & 84,00 ( Baik ) & 83,76 ( Baik ) \\
\hline 29. & Ns. & Ka. Bidang & 88,00 ( Baik ) & 89,56 ( Baik ) \\
\hline
\end{tabular}




\begin{tabular}{|c|c|c|c|c|}
\hline & $\begin{array}{l}\text { Pastridawanty } \\
\text { R.L.S, S. Kep. } \\
\text { M.Kes }\end{array}$ & $\begin{array}{l}\text { Sumber Daya } \\
\text { Kesehatan }\end{array}$ & & \\
\hline 30. & $\begin{array}{l}\text { Sevenris C D } \\
\text { Butar-butar, } \\
\text { SKM }\end{array}$ & $\begin{array}{l}\text { Ka. Seksi } \\
\text { Jaminan } \\
\text { Pemeliharaan } \\
\text { Kualitas } \\
\text { Kesehatan }\end{array}$ & 84,00 ( Baik ) & 86,76 ( Baik ) \\
\hline 31. & $\begin{array}{l}\text { Lestari } \\
\text { Ritonga, } \\
\text { Am.Keb }\end{array}$ & $\begin{array}{l}\text { Staf Seksi } \\
\text { Jaminan } \\
\text { Pemeliharaan } \\
\text { Kualitas } \\
\text { Kesehatan }\end{array}$ & 83,64 ( Baik ) & 80,27 ( Baik ) \\
\hline 32. & $\begin{array}{l}\text { Fransuwi } \\
\text { Lamhot } \\
\text { Sitorus, } \\
\text { S.Kom }\end{array}$ & $\begin{array}{l}\text { Staf Seksi } \\
\text { Jaminan } \\
\text { Pemeliharaan } \\
\text { Kualitas } \\
\text { Kesehatan }\end{array}$ & 80,00 ( Baik ) & 81,77 ( Baik ) \\
\hline 33. & $\begin{array}{l}\text { Ayu Lestari } \\
\text { br.Tarigan, } \\
\text { A.Md.Keb }\end{array}$ & $\begin{array}{l}\text { Staf Seksi } \\
\text { Jaminan } \\
\text { Pemeliharaan } \\
\text { Kualitas } \\
\text { Kesehatan }\end{array}$ & 82,37( Baik ) & 79,66 ( Baik ) \\
\hline 34. & $\begin{array}{l}\text { Merisurtiana } \\
\text { Tampubalon }\end{array}$ & $\begin{array}{l}\text { Ka. Seksi } \\
\text { Sumber Daya } \\
\text { Manusia } \\
\text { Kesehatan }\end{array}$ & 83,00 ( Baik ) & 80,47 ( Baik ) \\
\hline 35. & $\begin{array}{l}\text { Susi Lumban } \\
\text { Gaol }\end{array}$ & $\begin{array}{l}\text { Staf Seksi } \\
\text { Sumber Daya } \\
\text { Manusia } \\
\text { Kesehatan }\end{array}$ & 80,00 ( Baik ) & 78,96 ( Baik ) \\
\hline 36. & $\begin{array}{l}\text { Deli Maria } \\
\text { Sirait }\end{array}$ & $\begin{array}{l}\text { Staf Seksi } \\
\text { Sumber Daya } \\
\text { Manusia } \\
\text { Kesehatan }\end{array}$ & 78,00 ( Baik ) & 81,66 ( Baik ) \\
\hline 37. & $\begin{array}{l}\text { Dewi } \\
\text { Sihombing }\end{array}$ & $\begin{array}{l}\text { Staf Seksi } \\
\text { Sumber Daya } \\
\text { Manusia } \\
\text { Kesehatan }\end{array}$ & 82,00 ( Baik ) & 80,66 ( Baik ) \\
\hline 38. & Saidi Sibue & $\begin{array}{l}\text { Ka. Seksi Alat } \\
\text { Kesehatan dan } \\
\text { Perbekalan } \\
\text { Kesehatan } \\
\text { Rumah Tangga } \\
\text { (PKRT) }\end{array}$ & 87,88 ( Baik ) & 89,88 ( Baik ) \\
\hline
\end{tabular}




\begin{tabular}{|c|c|c|c|c|}
\hline 39. & $\begin{array}{l}\text { Rumondang } \\
\text { E. Sagala }\end{array}$ & $\begin{array}{l}\text { Staf Seksi Alat } \\
\text { Kesehatan dan } \\
\text { Perbekalan } \\
\text { Kesehatan } \\
\text { Rumah Tangga } \\
\text { (PKRT) }\end{array}$ & 84,66 ( Baik ) & 86,00 ( Baik ) \\
\hline 40. & $\begin{array}{l}\text { Ren Alfren C. } \\
\text { Hutagalung }\end{array}$ & $\begin{array}{l}\text { Staf Seksi Alat } \\
\text { Kesehatan dan } \\
\text { Perbekalan } \\
\text { Kesehatan } \\
\text { Rumah Tangga } \\
\text { (PKRT) }\end{array}$ & 85,00 ( Baik ) & 82,33 ( Baik ) \\
\hline 41. & $\begin{array}{l}\text { Marsaulina } \\
\text { Simamora }\end{array}$ & $\begin{array}{l}\text { Staf Seksi Alat } \\
\text { Kesehatan dan } \\
\text { Perbekalan } \\
\text { Kesehatan } \\
\text { Rumah Tangga } \\
\text { (PKRT) }\end{array}$ & 82,00 ( Baik ) & 78,00 ( Baik ) \\
\hline 42. & $\begin{array}{l}\text { Turpuk } \\
\text { Pandiangan, } \\
\text { SST, S.Pd, } \\
\text { M.Kes }\end{array}$ & $\begin{array}{l}\text { Ka. Bidang } \\
\text { Kesehatan } \\
\text { Masyarakat }\end{array}$ & 85,00 ( Baik ) & 87,67 ( Baik ) \\
\hline 43. & $\begin{array}{l}\text { Pesta Lumban } \\
\text { Toruan }\end{array}$ & $\begin{array}{l}\text { Ka. Seksi } \\
\text { Kesehatan } \\
\text { Keluarga dan } \\
\text { Gizi Masyarakat }\end{array}$ & 83,00 ( Baik ) & 83, 67 ( Baik ) \\
\hline 44. & $\begin{array}{l}\text { Riama M. } \\
\text { Siregar }\end{array}$ & $\begin{array}{l}\text { Staf Seksi } \\
\text { Kesehatan } \\
\text { Keluarga dan } \\
\text { Gizi Masyarakat }\end{array}$ & 82,47 ( Baik ) & 80,00 ( Baik ) \\
\hline 45. & $\begin{array}{l}\text { Tetty Uli H. } \\
\text { Parapat, } \\
\text { Am.Keb }\end{array}$ & $\begin{array}{l}\text { Staf Seksi } \\
\text { Kesehatan } \\
\text { Keluarga dan } \\
\text { Gizi Masyarakat }\end{array}$ & 85,00 ( Baik ) & 85,66 ( Baik ) \\
\hline 46. & $\begin{array}{l}\text { Rinnawaty } \\
\text { Sipahutar }\end{array}$ & $\begin{array}{l}\text { Staf Seksi } \\
\text { Kesehatan } \\
\text { Keluarga dan } \\
\text { Gizi Masyarakat }\end{array}$ & 86,44 ( Baik ) & 87,00 ( Baik ) \\
\hline 47. & $\begin{array}{l}\text { Derita } \\
\text { Marsinta Tua } \\
\text { Silitonga }\end{array}$ & $\begin{array}{l}\text { Staf Seksi } \\
\text { Kesehatan } \\
\text { Keluarga dan } \\
\text { Gizi Masyarakat }\end{array}$ & 83,00 ( Baik ) & 84,86 ( Baik ) \\
\hline 48. & Elfrida & Ka. Seksi & 85,57 ( Baik ) & 87,84 ( Baik ) \\
\hline
\end{tabular}




\begin{tabular}{|c|c|c|c|c|}
\hline & $\begin{array}{l}\text { Evalina } \\
\text { Pasaribu, SST, } \\
\text { M.Kes }\end{array}$ & $\begin{array}{l}\text { Promosi } \\
\text { Kesehatan dan } \\
\text { Pemberdayaan } \\
\text { Masyarakat }\end{array}$ & & \\
\hline 49. & $\begin{array}{l}\text { Nuri Marlena } \\
\text { Simatupang }\end{array}$ & $\begin{array}{l}\text { Staf Seksi } \\
\text { Promosi } \\
\text { Kesehatan dan } \\
\text { Pemberdayaan } \\
\text { Masyarakat }\end{array}$ & 84,00 ( Baik ) & 83,77 ( Baik ) \\
\hline 50. & $\begin{array}{l}\text { Mantili } \\
\text { Elfrida } \\
\text { Sihombing, } \\
\text { SKM }\end{array}$ & $\begin{array}{l}\text { Staf Seksi } \\
\text { Promosi } \\
\text { Kesehatan dan } \\
\text { Pemberdayaan } \\
\text { Masyarakat }\end{array}$ & 84,77 ( Baik ) & 83,36 ( Baik ) \\
\hline 51. & $\begin{array}{l}\text { Edward } \\
\text { Kingson } \\
\text { Sihombing, } \\
\text { AMK }\end{array}$ & $\begin{array}{l}\text { Ka. Seksi } \\
\text { Kesehatan } \\
\text { Lingkungan, } \\
\text { Kesehatan Kerja } \\
\text { dan Olahraga }\end{array}$ & 89,77 ( Baik ) & 89,82 ( Baik ) \\
\hline 52. & Junita & $\begin{array}{l}\text { Staf Seksi } \\
\text { Kesehatan } \\
\text { Lingkungan, } \\
\text { Kesehatan Kerja } \\
\text { dan Olahraga }\end{array}$ & 87,00 ( Baik ) & 87,68 ( Baik ) \\
\hline 53. & $\begin{array}{l}\text { Lenny Dian } \\
\text { Sari } \\
\text { Simanjuntak }\end{array}$ & $\begin{array}{l}\text { Staf Seksi } \\
\text { Kesehatan } \\
\text { Lingkungan, } \\
\text { Kesehatan Kerja } \\
\text { dan Olahraga }\end{array}$ & 86,66 ( Baik ) & 87,00 ( Baik ) \\
\hline 54. & $\begin{array}{l}\text { Dr. Tonny } \\
\text { Lumbantobing } \\
\text {, M.Kes }\end{array}$ & $\begin{array}{l}\text { Ka. Bidang } \\
\text { Pelayanan } \\
\text { Kesehatan }\end{array}$ & 89,88 ( Baik ) & 90,00 ( Baik ) \\
\hline 55. & $\begin{array}{l}\text { Andi MT. } \\
\text { Lumban } \\
\text { tobing, } \\
\text { S.Farm, Apt }\end{array}$ & $\begin{array}{l}\text { Ka.Seksi } \\
\text { Kefarmasian dan } \\
\text { Pelayanan } \\
\text { Kesehatan } \\
\text { Tradisional } \\
\end{array}$ & 88,00 ( Baik ) & 88,96 ( Baik ) \\
\hline 56. & $\begin{array}{l}\text { Adelina } \\
\text { Panggabean }\end{array}$ & $\begin{array}{l}\text { Staf Seksi } \\
\text { Kefarmasian dan } \\
\text { Pelayanan } \\
\text { Kesehatan } \\
\text { Tradisional } \\
\end{array}$ & 86,00 ( Baik ) & 86,87 ( Baik ) \\
\hline 57. & $\begin{array}{l}\text { Gustaf } \\
\text { Panggabean }\end{array}$ & $\begin{array}{l}\text { Staf Seksi } \\
\text { Kefarmasian dan } \\
\text { Pelayanan } \\
\text { Kesehatan }\end{array}$ & 86,77 ( Baik ) & 87,00 ( Baik ) \\
\hline
\end{tabular}




\begin{tabular}{|c|c|c|c|c|}
\hline & & Tradisional & & \\
\hline 58. & $\begin{array}{l}\text { Ernawaty } \\
\text { Prestu Siregar }\end{array}$ & $\begin{array}{l}\text { Staf Seksi } \\
\text { Kefarmasian dan } \\
\text { Pelayanan } \\
\text { Kesehatan } \\
\text { Tradisional }\end{array}$ & 85,76 ( Baik ) & 87,88 ( Baik ) \\
\hline 59. & $\begin{array}{l}\text { Edly } \\
\text { Syanurjanah }\end{array}$ & $\begin{array}{l}\text { Staf Seksi } \\
\text { Kefarmasian dan } \\
\text { Pelayanan } \\
\text { Kesehatan } \\
\text { Tradisional }\end{array}$ & 89,00 ( Baik ) & 88,77 ( Baik ) \\
\hline 60. & $\begin{array}{l}\text { Rotua Sinaga, } \\
\text { SKM }\end{array}$ & $\begin{array}{l}\text { Ka. Seksi } \\
\text { Pelayanan } \\
\text { Kesehatan } \\
\text { Primer }\end{array}$ & 87,00 ( Baik ) & 89,95 ( Baik ) \\
\hline 61. & $\begin{array}{l}\text { Rimpun } \\
\text { Pertua } \\
\text { Lumbantobing } \\
\text {, SKM }\end{array}$ & $\begin{array}{l}\text { Staf Seksi } \\
\text { Pelayanan } \\
\text { Kesehatan } \\
\text { Primer }\end{array}$ & 88,46 ( Baik ) & 88,88 ( Baik ) \\
\hline 62. & $\begin{array}{l}\text { Dr. Dermawan } \\
\text { Sinaga }\end{array}$ & $\begin{array}{l}\text { Ka. Seksi } \\
\text { Pelayanan } \\
\text { Kesehatan } \\
\text { Rujukan dan } \\
\text { Quick Respon }\end{array}$ & 89,80 ( Baik ) & 90,00 ( Baik ) \\
\hline 63. & $\begin{array}{l}\text { Nenni Aurelia } \\
\text { Parhusip, } \\
\text { Am.Keb }\end{array}$ & $\begin{array}{l}\text { Staf Seksi } \\
\text { Pelayanan } \\
\text { Kesehatan } \\
\text { Rujukan dan } \\
\text { Quick Respon }\end{array}$ & 86,00 ( Baik ) & 85,76 ( Baik ) \\
\hline 64. & $\begin{array}{l}\text { Septha Farel } \\
\text { Manosor } \\
\text { Ambarita }\end{array}$ & $\begin{array}{l}\text { Staf Seksi } \\
\text { Pelayanan } \\
\text { Kesehatan } \\
\text { Rujukan dan } \\
\text { Quick Respon } \\
\end{array}$ & 79,88 ( Baik ) & 82,00 ( Baik ) \\
\hline 65. & $\begin{array}{l}\text { Debby } \\
\text { Tarihoran }\end{array}$ & $\begin{array}{l}\text { Staf Seksi } \\
\text { Pelayanan } \\
\text { Kesehatan } \\
\text { Rujukan dan } \\
\text { Quick Respon }\end{array}$ & 83,00 ( Baik ) & 80,47 ( Baik ) \\
\hline 66. & $\begin{array}{l}\text { Dedy Ruditua } \\
\text { Saragih }\end{array}$ & $\begin{array}{l}\text { Staf Seksi } \\
\text { Pelayanan } \\
\text { Kesehatan } \\
\text { Rujukan dan } \\
\text { Quick Respon }\end{array}$ & 80,00 ( Baik) & 78,00 ( Baik ) \\
\hline
\end{tabular}




\begin{tabular}{|c|c|c|c|c|}
\hline 67. & $\begin{array}{l}\text { Nadya Fatma } \\
\text { Panggabean }\end{array}$ & $\begin{array}{l}\text { Staf Seksi } \\
\text { Pelayanan } \\
\text { Kesehatan } \\
\text { Rujukan dan } \\
\text { Quick Respon }\end{array}$ & 79,00 ( Baik ) & 78,76 ( Baik) \\
\hline 68. & Hotmaida & $\begin{array}{l}\text { Staf Seksi } \\
\text { Pelayanan } \\
\text { Kesehatan } \\
\text { Rujukan dan } \\
\text { Quick Respon }\end{array}$ & 83,00 ( Baik ) & 81,67 ( Baik ) \\
\hline 69. & Erna Sibarani & $\begin{array}{l}\text { Staf Seksi } \\
\text { Pelayanan } \\
\text { Kesehatan } \\
\text { Rujukan dan } \\
\text { Quick Respon }\end{array}$ & 83,67 ( Baik ) & 82,00 ( Baik ) \\
\hline 70. & $\begin{array}{l}\text { Nenny Evi P. } \\
\text { Siallagan }\end{array}$ & $\begin{array}{l}\text { Staf Seksi } \\
\text { Pelayanan } \\
\text { Kesehatan } \\
\text { Rujukan dan } \\
\text { Quick Respon }\end{array}$ & 80,78 ( Baik ) & 79,88 ( Baik ) \\
\hline 71. & $\begin{array}{l}\text { Risma } \\
\text { Panjaitan, } \\
\text { SST. M.Kes }\end{array}$ & $\begin{array}{l}\text { Ka. Bidang } \\
\text { Pencegahan } \\
\text { Penyakit }\end{array}$ & 88,00 ( Baik ) & 89,80 ( Baik ) \\
\hline 72. & $\begin{array}{l}\text { Manginar } \\
\text { Pangaribuan, } \\
\text { SH }\end{array}$ & $\begin{array}{l}\text { Ka. Seksi } \\
\text { Surveilens dan } \\
\text { imunisasi }\end{array}$ & 89,77 ( Baik ) & 89,80 ( Baik ) \\
\hline 73. & $\begin{array}{l}\text { Nurmala } \\
\text { Panjaitan }\end{array}$ & $\begin{array}{l}\text { Staf Seksi } \\
\text { Surveilens dan } \\
\text { imunisasi }\end{array}$ & 86,77 ( Baik ) & 86,00 ( Baik ) \\
\hline 74. & $\begin{array}{l}\text { Jakson Marlon } \\
\text { Siahaan, } \\
\text { S.Kep, Ns }\end{array}$ & $\begin{array}{l}\text { Staf Seksi } \\
\text { Surveilens dan } \\
\text { imunisasi }\end{array}$ & 82,67 ( Baik ) & 83,00 ( Baik ) \\
\hline 75. & $\begin{array}{l}\text { Sarma } \\
\text { Doharma } \\
\text { Panggabean }\end{array}$ & $\begin{array}{l}\text { Staf Seksi } \\
\text { Surveilens dan } \\
\text { imunisasi }\end{array}$ & 83,67 ( Baik ) & 80,68 ( Baik) \\
\hline 76. & $\begin{array}{l}\text { Selfi } \\
\text { Tampubolon }\end{array}$ & $\begin{array}{l}\text { Staf Seksi } \\
\text { Surveilens dan } \\
\text { imunisasi }\end{array}$ & 82,67 ( Baik ) & 81,00 ( Baik ) \\
\hline 77. & $\begin{array}{l}\text { Arisonang } \\
\text { hutagalung, } \\
\text { S.Kep, Ns }\end{array}$ & $\begin{array}{l}\text { Ka. Seksi } \\
\text { Penyakit } \\
\text { Menular dan } \\
\text { Zoonis }\end{array}$ & 87,77 ( Baik) & 88,00 ( Baik ) \\
\hline 78. & $\begin{array}{l}\text { Rosinta } \\
\text { Marito M. } \\
\text { Hutabarat }\end{array}$ & $\begin{array}{l}\text { Staf Seksi } \\
\text { Penyakit } \\
\text { Menular dan } \\
\text { Zoonis }\end{array}$ & 84,66 ( Baik ) & 83,00 ( Baik) \\
\hline
\end{tabular}




\begin{tabular}{|c|c|c|c|c|}
\hline 79. & $\begin{array}{l}\text { Agustinus } \\
\text { Nahampun }\end{array}$ & $\begin{array}{l}\text { Staf Seksi } \\
\text { Penyakit } \\
\text { Menular dan } \\
\text { Zoonis }\end{array}$ & 83,00 ( Baik ) & 82,67 ( Baik ) \\
\hline 80. & $\begin{array}{l}\text { Bethsyeba } \\
\text { Nababan }\end{array}$ & $\begin{array}{l}\text { Staf Seksi } \\
\text { Penyakit } \\
\text { Menular dan } \\
\text { Zoonis }\end{array}$ & 86,77 ( Baik ) & 86,27 ( Baik) \\
\hline 81. & $\begin{array}{l}\text { Cipto } \\
\text { Rajaguguk }\end{array}$ & $\begin{array}{l}\text { Staf Seksi } \\
\text { Penyakit } \\
\text { Menular dan } \\
\text { Zoonis }\end{array}$ & 85,39 ( Baik ) & 84,00 ( Baik ) \\
\hline 82. & Gustaf Sinaga & $\begin{array}{l}\text { Staf Seksi } \\
\text { Penyakit } \\
\text { Menular dan } \\
\text { Zoonis }\end{array}$ & 86,00 ( Baik ) & 84,87 ( Baik ) \\
\hline 83. & $\begin{array}{l}\text { Tiurmaida } \\
\text { Siahaan }\end{array}$ & $\begin{array}{l}\text { Ka. Seksi } \\
\text { Penanggulangan } \\
\text { Penyakit Tidak } \\
\text { Menular dan } \\
\text { Kesehatan Jiwa }\end{array}$ & 89,00 ( Baik ) & 90,00 ( Baik ) \\
\hline 84. & $\begin{array}{l}\text { Kristopel } \\
\text { Sitompul }\end{array}$ & $\begin{array}{l}\text { Staf Seksi } \\
\text { Penanggulangan } \\
\text { Penyakit Tidak } \\
\text { Menular dan } \\
\text { Kesehatan Jiwa }\end{array}$ & 87,67 ( Baik ) & 87,00 ( Baik ) \\
\hline 85. & $\begin{array}{l}\text { Nurlia } \\
\text { Napitupulu }\end{array}$ & $\begin{array}{l}\text { Staf Seksi } \\
\text { Penanggulangan } \\
\text { Penyakit Tidak } \\
\text { Menular dan } \\
\text { Kesehatan Jiwa }\end{array}$ & 86,87 ( Baik ) & 85,00 ( Baik ) \\
\hline 86. & $\begin{array}{l}\text { Halomoan } \\
\text { Roselina }\end{array}$ & $\begin{array}{l}\text { Staf Seksi } \\
\text { Penanggulangan } \\
\text { Penyakit Tidak } \\
\text { Menular dan } \\
\text { Kesehatan Jiwa }\end{array}$ & 87,77 ( Baik ) & 86,60 ( Baik ) \\
\hline
\end{tabular}

Pejabat Penilai, 


\section{LAMPIRAN J}

Surat Keterangan Bukti Penelitian dan Selesai

Penelitian 


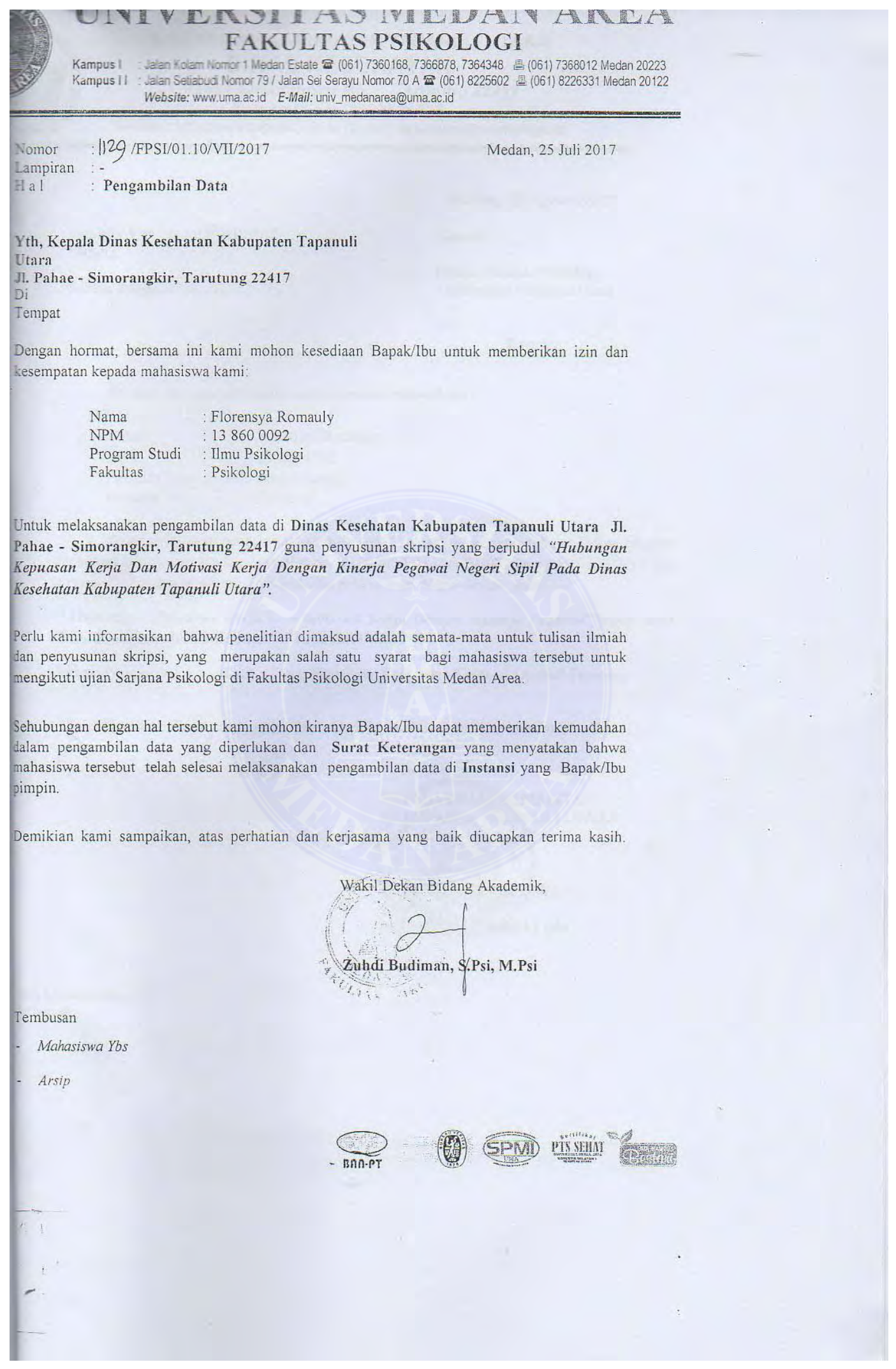




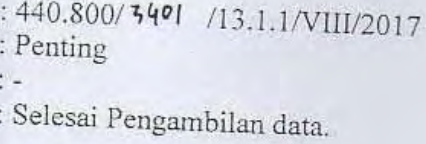

\section{PEMERINTAH KABUPATEN TAPANULI UTARA \\ DINAS KESEHATAN}

Tarutung 22417

on/Fax: (0633) 21135

Tarutung, 07 Agustus 2017

Kepada

Yth. Dekan Fakultas Psikologi Universitas Sumatera Utara di -

$$
\text { Tempat. }
$$

Bersama ini kami sampaikan bahwa tersebut dibawah ini :

$\begin{array}{ll}\text { Nama } & \text { : Florensya Romauly } \\ \text { NPM } & : 138600092 \\ \text { Program Studi } & \text { : Ilmu Psikologi } \\ \text { Fakultas } & \text { : Psikologi }\end{array}$

Benar melakukan pengambilan data dan telah selesai sesuai dengan Surat Dekan fakultas Psikologi Universitas Medan Area Nomor : 1129/FPSU/01.10/VII/2017 tanggal 25 Juli $2017 \mathrm{Ha}$ : Pengambilan data, guna tulisan ilmiah dan penyusunan skripsi dengan judul :

"Hubungan Kepuasan Kerja Dan Motivasi Kerja Dengan Kinerja Pegawai Negeri Sipil Pada Dinas Kesehatan Kabupaten Tapanuli Utara."

Lokasi Penelitian

$$
\text { : Kantor Dinas Kesehatan Kabupaten Tapanuli Utara di Tarutung }
$$

Demikian disampaikan untuk dapat dipergunakan sebagaimana mestinya.

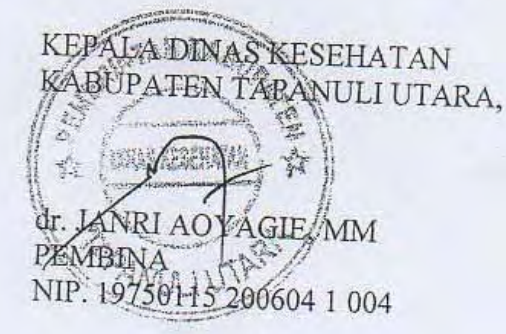

ig bersangkutan;

tinggal. 